Rhode Island College

Digital Commons @ RIC

$10-25-2018$

\title{
The Inequities of Motherhood: The Challenges of Obstetric Anesthesia in Low-Income Countries
}

Mary Kate Ricci

Follow this and additional works at: https://digitalcommons.ric.edu/etd

Part of the Other Nursing Commons

\section{Recommended Citation}

Ricci, Mary Kate, "The Inequities of Motherhood: The Challenges of Obstetric Anesthesia in Low-Income Countries" (2018). Master's Theses, Dissertations, Graduate Research and Major Papers Overview. 280. https://digitalcommons.ric.edu/etd/280

This Major Paper is brought to you for free and open access by the Master's Theses, Dissertations, Graduate Research and Major Papers at Digital Commons @ RIC. It has been accepted for inclusion in Master's Theses, Dissertations, Graduate Research and Major Papers Overview by an authorized administrator of Digital Commons @ RIC. For more information, please contact digitalcommons@ric.edu. 
THE INEQUITIES OF MOTHERHOOD:

THE CHALLENGES OF OBSTETRIC ANESTHESIA IN LOW-INCOME COUNTRIES

\author{
by \\ Mary "Katie” Ricci \\ A Major Paper Submitted in Partial Fulfillment \\ of the Requirements for the Degree of \\ Master of Science in Nursing \\ in \\ The School of Nursing \\ Rhode Island College \\ 2018
}




\begin{abstract}
The maternal mortality rate (MMR) is unconscionably high around the world, with women in low to middle income countries (LMICs) disproportionately passing away from potentially preventable causes. While this is a complicated and multifaceted problem, anesthesia has been identified as a contributing cause of death. From the moment the parturient enters the operating room, the anesthetist is responsible for their well-being. This integrative review was designed to further explore relationship between anesthesia and the MMR in LMICs. Twelve articles published within the last 15 years were selected through an extensive literature search using Medline and CINAHL. Each article was examined using the Polit and Beck (2017) assessment criteria followed by a cross table analysis. The results identified common themes across the studies including lack of infrastructure such as access to reliable power, water and oxygen, resources such as medications and basic anesthesia equipment, training focusing on maternal care and anesthesia and continuing education for providers. Knowing these deficiencies in anesthetic care, nurse anesthetists can assist in implementing changes to help reduce the MMR. Recommendations include encouraging hospitals and governments to make updating hospital infrastructure a priority, reaching out to groups such as the World Health Organization who help fund basic equipment such as pulse oximeters, establishing relationships with medical institutions in other regions to provide training and guidance, and focusing on the development of non-physician anesthetist programs to increase the number of proficient providers.
\end{abstract}




\section{Table of Contents}

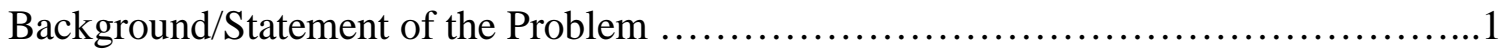

Literature Review.............................................................

Theoretical Framework............................................................

Method.........................................................................

Results...................................................................20

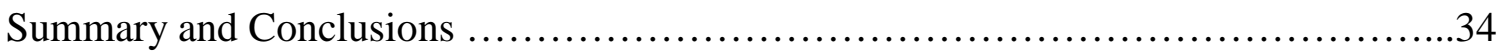

Recommendations and Implications for Advanced Nursing Practice....................37

References.................................................................40

Appendices..............................................................45 
THE INEQUITIES OF MOTHERHOOD:

THE CHALLENGES OF OBSTETRIC ANESTHESIA IN LOW- INCOME COUNTRES

\section{Background/Statement of the Problem}

Pregnancy is status-celebrated worldwide, however for many women it comes with great risk. Giving birth in countries like the United States and other high-income countries is widely considered a safe endeavor, yet in low and lower-middle-income countries (LMICs), pregnancy and the subsequent delivery is often more precarious. The World Health Organization (WHO, 2018) reported as many as 830 women die daily from preventable causes during pregnancy and childbirth and 99\% of these deaths occur in LMICs. Hemorrhage, infection, eclampsia, and complications from delivery and unsafe abortions account for $75 \%$ of maternal deaths. The United Nations Sustainable Development Goals (2017) addressed the continued need to reduce maternal mortality ratio (MMR) from 239 to 70 per 100,000 live births in LMICs. Initiatives such as Safe Surgery Saves Lives and the WHO Pulse Oximetry Project work toward achieving this objective.

When women present to a health clinic or hospital with one of the many complications that can accompany childbirth, surgery is often the definitive treatment. Anesthesia, an integral part of the surgical process, is a complex undertaking under ideal conditions, yet in LMICs ideal conditions are a rarity. Many hospitals lack medications and equipment that are considered a standard of care in the United States. One study, conducted in 2012 (Vo, Cherian, Bianchi, Noel, \& Lundeg) reported that only 35\% of facilities surveyed had access to oxygen and only $53.4 \%$ had access to a functioning anesthesia machine. In many hospitals, anesthesia is not performed by trained providers, 
such as anesthesiologists or nurse anesthetists, but instead by untrained personnel such as surgical techs or nursing aides. In Uganda, for example, there was estimated to be only 14 physician-anesthesiologists for a country of over 30 million people (Dubowitz, Detlefs, \& McQueen, 2010). It has been estimated that safe obstetric anesthesia can reduce maternal deaths by 5\% (Rosseel, Trelles, Guilavogui, Ford, \& Chu, 2010); however achieving this target requires a complex and multifaceted approach.

The purpose of this integrative review is to identify the anesthesia-related factors that contribute to the disproportionate MMR for obstetric patients in low-to-middleincome countries as well as determine what strategies can be used to reduce maternal anesthesia morbidity and mortality.

Next, the review of the literature will be presented. 


\section{Literature Review}

Databases searched included Medline and CINAHL. The keywords included anesthesia, developing countries, developing nations, third world, low income countries, maternal anesthesia, morbidity and mortality. All studies within the last 15 years, 20022017, were included in the search.

\section{Maternal Mortality}

The WHO (2017) defined maternal death as "the death of a woman while pregnant or within 42 days of termination of pregnancy, irrespective of the duration and site of the pregnancy, from any cause related to or aggravated by the pregnancy or its management but not from accidental or incidental causes” (Para 2). The MMR is a measurement tool used globally to quantify the risk associated with pregnancy in individual countries (The World Bank, 2015). Maternal health and reducing the MMR became a primary focus in international development in the 1990s and was incorporated into the millennium development goals launched by the United Nations, with the target of reducing the MMR by three-quarters by 2015 (WHO, 2015a). Despite a 45\% global reduction, LMICs still have a disproportionately high MMR when compared to highincome countries. For example, according to The World Bank (2015), the MMR in the United States in 2015 was 15 per 100,000 people in contrast to Sierra Leone where it was $1,360$.

In order to understand the reason for this disparity, authors Khan, Wojdyla, Say, Gülmezoglu, and Van Look (2006) performed a systematic review examining the numerous causes of maternal death. Of an initial 1143 datasets identified, a total of 34 were analyzed. In Africa and Asia, hemorrhage was the leading cause of maternal death, 
accounting for 33.9\% and 30.8\% respectively. In Latin American and the Caribbean, hypertensive disorders represent the highest cause of death with an incidence of $25.7 \%$. Abortion-related deaths was highest in Latin America and the Caribbean at $12 \%$, yet in certain areas could be as high as 30\% of the MMR. Other contributing causes included sepsis/infections, HIV/AIDS status and obstructed labor. By identifying the primary causes of maternal death in different regions, evidence-based policies, programs and interventions can be implemented regionally to reduce the burden of disease. Where deaths due to abortion are high, for example, examining the influence of restrictive abortion laws on the MMR could lead to country-wide changes in policy to reduce unsafe abortion practices.

\section{Cesarean Sections in LMICs}

In a statement on cesarean section rates, the WHO (2015b) asserted that when medically appropriate, cesarean sections rates of $10 \%$ reduce maternal mortality. However, rates above $10 \%$ do not show any significant change in maternal outcome (WHO, 2015b). When cesareans are performed, it is essential that facilities are adequately staffed and supplied to avoid complications, disability or death.

Showing data in support of the WHOs recommendations, authors Althabe et al. (2006) performed a cross-sectional, multi-group ecological study including 119 countries from 1991-2003. Included were a mix of high, middle and low-income countries and linear regression models were used to assess the association between maternal and neonatal mortality and cesarean delivery rates. Of the low-income countries, $76 \%$ had cesarean rates between $0-10 \%$ whereas only one high-income country had cesarean rates 
within that range. Low cesarean rates and maternal mortality showed a negative and statistically significant correlation $(\mathrm{p}<0.0001)$ in low-income countries but not in middle or high-income countries. This suggests a need for continuing education among providers to identify who is in need of a cesarean. Also, referral systems, availability of facilities and transportation to specialized care are requisite for providing cesareans when necessary.

However, excessive rates of cesarean delivery are also associated with poor maternal outcomes. In an article by Villar et al. (2006), data regarding cesarean sections and maternal morbidity from eight countries in Latin America, a region known globally for high rates of cesarean deliveries, were analyzed using linear regression models. They found the median rate of cesarean delivery to be 33\%, with the highest noted in private hospitals at a rate of $51 \%$. Cesarean delivery was positively correlated with postpartum antibiotic administration ( $\mathrm{p}=0.004)$ indicating an increased risk of infection. Maternal morbidity and mortality also increased with higher rates of cesarean deliveries, including the need for blood transfusions and prolonged hospital stays. These two studies suggest an important balance between necessary and excessive use of cesarean delivery in LMICs. Developing international standards of care to help identify when cesarean section is needed is an important step in the overall reduction of maternal morbidity.

Authors Ronsmans, Holtz, and Stanton (2006) addressed the influence of socioeconomic factors on cesarean rates in a retrospective analysis of 199,916 deliveries in 42 countries between 1988-2002. Countries from most continents were represented, including 26 from sub-Saharan Africa, seven in South and Southeast Asia and nine in Latin America and the Caribbean. Together, they represented 59\% of all livebirths in the 
developing world. Of these 42 countries, 14 had cesarean rates of less than 2\%, 13 countries had cesarean rates between $2-4.9 \%$ and the remaining 15 had rates of $5 \%$ or more. For those representing the poorest $20 \%$ of a population, cesareans were performed in less than $1 \%$ of pregnant women. In countries with overall cesarean rates of less than $2 \%$, the median ratio between rich to poor was $11: 7$; with rates of $2-4.9 \%$, the median ratio was 9:3; and in less than $5 \%$, the median ratio was 7:0. There was also a more significant rate $(\mathrm{p}<0.05)$ of cesarean deliveries among the urban rich and rural rich in 26 of the 42 countries (p. 1521). Researchers also found access to functioning hospital services was extremely limited in LMICs, with the average distance between hospitals in some countries over 80 kilometers. This presents a clear disparity between the rich and poor in both urban and rural communities.

\section{Obstetric Anesthesia}

In the United States, obstetrics is considered a subspecialty of anesthesia practice. The laboring mother is a unique patient due to changes in anatomy, drug metabolism and other distinctive physiology. Neuraxial anesthesia is widely accepted as the safest form of obstetric anesthesia in the majority of cases; however in certain emergencies general anesthesia is used. The American Society of Anesthesiologists (2016) recommended neuraxial anesthesia, such as an epidural, in their general guidelines for most cesarean sections but stated it is ultimately up to the provider and dependent on each individual situation. The anesthetic, obstetric and fetal risk factors, as well as patient preference, should all be taken into account when deciding what form of anesthesia to use.

The ASA Task Force on Obstetric Anesthesia and the Society for Obstetric Anesthesia and Perinatology released updated practice guidelines in 2016 to "enhance the 
quality of anesthetic care for obstetric patients, improve patient safety by reducing the incidence and severity of anesthesia related complications, and increase patient satisfaction” (p. 1). Guidelines were developed in accordance with scientific and opinionbased evidence. Regarding anesthetic care for cesarean delivery it is recommended that:

1. Equipment, facilities and support personnel available in the labor and delivery operating suite should be comparable to those in the main operating suite;

2. Resources for the treatment of potential complications (e.g., failed intubation, inadequate analgesia/anesthesia, hypotension, respiratory depression, local anesthetic systemic toxicity, pruritus, and vomiting) should be available in the labor and delivery operating suite;

3. Appropriate equipment and personnel should be available to care for obstetrics patients recovering from neuraxial or general anesthesia (p. 8). Wherever a cesarean delivery is performed, personnel must be prepared to deal with the potential complications of obstetric anesthesia and therefore should be specialty-trained to recognize when interventions are needed. When encountered with an obstetric and anesthetic emergency the guidelines state:

1. Institutions providing obstetric care should have resources available to manage hemorrhagic emergencies;

2. Labor and delivery units should have personnel and equipment ready to manage airway emergencies consistent with the ASA practice guidelines for management of the difficult airway, to include a pulse oximeter and carbon dioxide detector; 
3. Basic and advanced life-support equipment should be immediately available in the operative area of labor and delivery units (p. 14).

\section{Obstetric Anesthesia in LMICs}

These practice parameters were created for use in the United States where anesthesia care is well established and supplies and monitoring equipment are readily available. The standards of care established by the ASA and the American Association of Nurse Anesthetists (AANA) are well adhered to and enforced. However, in other areas of the world, standards of care may or may not be present and due to infrastructure deficiencies are not consistently enforced. In the article “Obstetric Anesthesia in Low- Resource Settings,” authors Dyer, Reed, and James (2010) presented guiding principles for practicing anesthesia for cesarean section and obstetric emergencies in LMICs. They state the requirements for safe practice are:

1. Skills, in the form of adequately trained staff and educational resources;

2. Appropriate anesthesia monitors, disposables and drugs;

3. Relevant management protocols for each level of care, with supervision and audit (p. 9).

The authors also suggested the use of nurse anesthetists or other non-physician providers as one strategy to ensure an adequate number of trained anesthesia staff in LMICs. They can be well trained in a shorter time frame and are likely to remain within their community. Equipment is often donated to hospitals; however, a lack of proper instruction and maintenance leads to ‘equipment graveyards’ where advanced supplies are left unused and more practical, everyday items are not available. Electricity and the ability to have compressed gas is not reliably available in every region; therefore, 
vaporizers that can do draw-over methods should be used instead of only continuous flow. Single-use spinal needles are often donated, but they are often expired and frequently reused in low-resource facilities, increasing the risk of infection. Minimum monitoring should include an electrocardiogram or pulse oximetry and blood pressure monitoring throughout treatment is vital. Capnography for endotracheal tube placement confirmation is essential to ensure proper oxygenation. Oxygen analyzers should be mandatory and volatile anesthetic monitoring reduces the chances of awakening during surgery (Dyer et al., 2010).

The availability of drugs is often limited so familiarity with what is available is required. For spinal anesthesia, hyperbaric bupivacaine and fentanyl are ideal and vasopressors such as ephedrine and phenylephrine need to be on hand for hypotension. Hydralazine and labetalol should be used for management of hypertensive disorders and magnesium sulfate for pre-eclampsia. The overall message is that standardized protocols should be established for both general and spinal anesthesia as obstetric anesthesia is complex and can have disastrous outcomes. Ensuring a safe anesthetic method that is evidenced-based decreases the risk of complications, and adequate supplies are needed to provide proper care (Dyer et al., 2010).

\section{Anesthesia Deficiency in LMICs}

In the developing world, women are disproportionately dying from pregnancyrelated complications, many of which require surgical intervention. However, a lack of supplies, medications, and specialty trained staff leads to poor surgical outcomes, many of which are directly related to anesthetic interventions. Authors Vo et al. (2012) evaluated the capacity of anesthetic services in 22 low and middle income countries 
including Indonesia, Malawi, Pakistan, Sao Tome and Principe, China, Democratic Republic of the Congo, Sierra Leone, Ethiopia, Vietnam, Ghana, Liberia, Niger, Papua New Guinea, India, Afghanistan, Sri Lanka, Uganda, United Republic of Tanzania, Kenya, Nigeria, Mongolia, and Gambia. Infrastructure, personnel, anesthesia equipment, and anesthesia types offered were analyzed to determine what resources were available and what deficiencies impacted care. Uninterrupted water, electricity and access to oxygen had limited availability in facilities at $62.4 \%$, 59\% and $45.2 \%$ respectively. Only $53.4 \%$ of facilities had reliable access to a functioning anesthesia machine and $53 \%$ had access to a pulse oximeter. Nurses and clinical assistants made up the majority of the anesthesia workforce regardless of the facility. Regional anesthesia was available in 56\% of facilities and spinal anesthesia in $65.5 \%$. General inhaled anesthesia was present in $58.5 \%$ of facilities and ketamine in $71.5 \%$. The seemingly simple aspects of anesthesia, such as oxygen are taken for granted in high-income countries, but in many places are a luxury.

There is a global deficiency in healthcare providers, with a current shortfall of 7.2 million in 2013, a number that is continuously rising (WHO, 2013). Data from the WHO Global Surgical Workforce Database, which was gathered from 167 countries that together contain $92 \%$ of the world's population, estimated that LMICs have $15 \%$ of the global anesthesia workforce despite representing 48\% of the population (WHO, 2016). Authors Dubowitz et al. (2010) created an internet-based survey to estimate the anesthesia workforce in LMICs. They found an average of less than 1 physician or nonphysician anesthesia provider per 100,000 population. In comparison, the United States has an estimated ratio of 1 per 4,000. Yemen had the lowest, with 0.07 providers per 
100,000 people and Swaziland had the highest with 1.14 per 100,000 . Tanzania, at the time of the survey, had only four residents in training and Zimbabwe trained the most with 150 residents per year. Uganda and Kenya had started anesthesia officer and nurse anesthetist training programs in an attempt to reduce the anesthesia burden. Malawi, Nepal, Iran and Mozambique also successfully implemented programs that train them to perform basic perioperative patient management. However due to a lack of experienced providers, educating non-physician providers comes with an additional challenge creating problems with initial training, skill maintenance and general oversight. Monetary compensation is also a factor in retaining providers, with migration to resource-rich countries a continuous challenge for LMICs (Dubowitz et al.).

\section{Reducing the Maternal Morbidity and Mortality Rate}

Knowing a problem exists is only the first step. The real challenge lies in how to reduce the MMR in LMICs. Due to the multifactorial etiology, a quick fix unfortunately does not exist. Task shifting, as defined by the WHO (2006) is "a process of delegation whereby tasks are moved, where appropriate, to less specialized health workers” (p. 3). Mid-level practitioners, such as CRNAs in the United States, have been used since the early 1900s and play a crucial role in providing anesthesia to all populations. Authors Mavalankar and Sriram (2009) performed a review of the literature including the need for task shifting in South East Asia and the training programs provided in each country. In Nepal, a significant shortage of medical officers and specialists combined with difficult terrain creates challenges in providing adequate anesthesia care. In 1996, Nepal started an anesthesia assistant (AA) program which, at the time of the article, trained 74 providers. The program saw an increased number of surgeries performed at hospitals with AAs as 
well as overall retention of providers within the country. India started a program in 2003 and since has trained over 500 providers with support from the government.

Authors Dubowitz and Evans (2012) addressed the shortage of anesthesia providers in LMICs by suggesting guidelines for developing a curriculum for anesthesia training programs for physician and non-physician providers. Programs should be tailored to each countries' individual needs, including those with few or no physician providers, those with long-established anesthesia training programs but with poor or underdeveloped infrastructure and those established programs in which graduates or educators may be lacking specific skills, resources or oversight. First, a relationship must be established with interested parties in an atmosphere of collaboration. This should be followed by the development of a culturally appropriate program. Finally, how local students incorporate new information should be taken into account (Dubowitz \& Evans).

Sustainable change is paramount to a new programs success and outside support should be able to withdraw over time. In Rwanda, the Safer Anesthesia From Education (SAFE) Obstetric Anesthesia Course was developed by the Association of Anesthetists of Great Britain and Ireland to educate providers in obstetric anesthesia and improve practice (Livingston et al., 2014). This three day course contains lectures, active teaching methods and small group stations to practice skills and scenarios. New trainers are educated so that future programs can continue without outside support. Follow up interviews were conducted six months after the course and practice improvements were reported such as better preparation for anesthesia and systematic management of emergencies. If more providers can be trained and continuing education can be provided, more women will have access to competent and safer care. 
Next, the theoretical framework guiding this paper will be presented. 


\section{Theoretical Framework}

Obstetric death as it relates to anesthesia is a complex, multifaceted problem that cannot be traced to a sole cause. The Three Delays Framework, created by Sereen Thaddeus and Deborah Maine in 1994, considers the complexity of maternal mortality in the developing world and identifies a series of delays in reaching definitive care, starting with the onset of complications to the provision of treatment. Phase I delay is the decision to seek care on the part of the individual, the family, or both. This is influenced by distance, cost, quality of care, illness factors, women's status within the community, economic status and educational status. Phase II delay is the delay in reaching an adequate health care facility, which involves the distribution of facilities, travel distances, transportation and deaths on the way to the hospital. Lastly, Phase III delay is the delay in receiving adequate care as a result of ill-staffed or ill-equipped facilities. The framework emphasizes the interconnection of each phase and how one invariably influences another, however each phase on its own can also result in a fatality.

The Three Delays Framework was used by authors Barnes-Josiah, Myntti, and Augustin (1998) to examine maternal mortality in Haiti. Haiti, the poorest country in the Western hemisphere, has one of the highest maternal mortality rates in the world with an MMR of 359 (per 100,000 live births) (The World Bank, 2015). Using the framework, they found that the first and third delay primarily influenced obstetric care utilization. Of the 12 cases of maternal death studied, eight of them either delayed going to the hospital or elected not to go at all, with the perception of inadequate or ineffective care as a primary influence in this decision making. For those who did make it to the hospital, one encountered a facility that was unable to perform a cesarean section, while six others 
received ineffective or no treatment at all. The authors concluded that in each case of death to the parturient, not one single delay could be identified as the cause of mortality but instead the interplay of all three lead to their tragic and preventable demise.

Authors Pacagnella, Cecatti, Osis, and Souza (2012) took the Three Delays Framework one step further and considered maternal mortality and morbidity by also incorporating the maternal "near-miss” approach to recognize critical events around childbirth. In their literature review, the authors collected data including autopsies, indepth interviews, and systematic audits of cases. In the course of the review a "Phase Four” delay was identified addressing women who survive the primary complications of childbirth but later suffer from an acute or chronic clinical condition resulting from the interventions that initially saved her life. Examples would be an infectious disease such as hepatitis from blood transfusion or a surgical site infection from the cesarean incision. The authors also recognized the limitations of the Three Delays Theory and its reference to only emergency obstetric care and not primary prevention and early detection.

When considering maternal anesthesia, the Three Delays Framework explicitly addresses the consequences of ill-prepared facilities and personnel in its third phase. However, acknowledgement of the influence of the Phase I and Phase II two delays is paramount when scrutinizing maternal mortality. There must be a trust in anesthesia providers so that the parturient is confident in the care she will receive at the hospital. Community outreach, education and an established relationship between providers and those receiving care must be worked into all interventions. Specialists in obstetric anesthesia must not exclusively work in large city centers where access to a large portion of the population is extremely limited. Rural hospitals must be staffed with those 
knowledgeable about the unique challenges of the obstetric patient. Finally, an understanding of the culture is paramount to success around the world. Providers must be cognizant of the social and religious beliefs of those they are treating and be able to provide culturally appropriate care, adjusting their anesthetic plan as needed to gain the trust and confidence of their patients so they will not hesitate to seek care for future needs.

Next, the method will be discussed. 


\section{Method}

\section{Purpose/clinical question/outcomes to be examined}

Obstetric anesthesia requires specialty training, medication and equipment that is often lacking in LMICs. Further, social and infrastructure factors influence the care received by these women. As a result, the parturient suffers and the MMR continues to be excessively high. The purpose of this integrative review was to identify the anesthesiarelated factors that contribute to the disproportionately high MMR for obstetric patients in low-to-middle-income countries as well as determine what strategies can be used to reduce maternal anesthesia morbidity and mortality.

\section{Inclusion/exclusion criteria/limits}

Inclusion criteria included randomized control trials, systematic reviews, case reports and qualitative studies conducted in LMICs involving anesthesia and the obstetric patient and published within the last 15 years. The definition of an obstetric patient followed that used by the WHO: women within 42 days of the termination of pregnancy or those who suffered morbidity or mortality from causes related to pregnancy (World Health Organization, 2017). Exclusion criteria included studies in foreign languages, studies from over 15 years ago, studies from high-income countries, and those including non-pregnant patients outside of 42 days of termination of pregnancy.

\section{Search Strategy}

Databases searched included Medline and CINAHL. All studies within the last fifteen years, 2002-2017, were included in the search. Key words included “anesthesia” or “maternal anesthesia,” various iterations of LMIC including “developing countries” or “developing nations” or “third world,” or “low income countries,” and “morbidity” or 
“mortality.” Surgical obstetric related search terms were also added in including

“cesarean section” or “tubal ligation” or “abortion.” Additionally, article references were searched to identify additional studies. Titles and abstracts were all screened followed by reading of full texts of relevant works. The goal was to find between 15 and 20 articles to be used in this integrative review. Table 1 illustrates the literature found with each search term.

Table 1

\section{Literature Search}

\begin{tabular}{|l|l|l|}
\hline \multicolumn{1}{|c|}{ Search Term (Within Last 15 years) } & Medline & CINAHL \\
\hline $\begin{array}{l}\text { Anesthesia AND developing countries OR developing nations } \\
\text { OR third world OR low income countries }\end{array}$ & 749 & 155 \\
\hline $\begin{array}{l}\text { Maternal anesthesia AND developing countries OR developing } \\
\text { nations OR third world OR low income countries }\end{array}$ & 73 & 15 \\
\hline $\begin{array}{l}\text { Maternal anesthesia AND developing countries or developing } \\
\text { nations or third world or low income countries AND morbidity }\end{array}$ & 29 & 1 \\
\hline $\begin{array}{l}\text { Maternal anesthesia AND developing countries OR developing } \\
\text { nations OR third world OR low income countries AND mortality }\end{array}$ & 45 & 11 \\
\hline $\begin{array}{l}\text { Anesthesia AND developing countries OR developing nations } \\
\text { OR third world OR low income countries AND cesarean section } \\
\text { OR tubal ligation OR abortion }\end{array}$ & 172 & 13 \\
\hline
\end{tabular}

\section{Data collection}

Relevant data were synthesized in a table created by the author (Table 2). This table has been adapted from one created by Anderson et al. (2014).

Table 2

\section{Data Collection Sheet}

\begin{tabular}{|l|l|}
\hline Objective & \\
\hline Findings & \\
\hline $\begin{array}{l}\text { Anesthesia-related causes of } \\
\text { morbidity and mortality }\end{array}$ & \\
\hline $\begin{array}{l}\text { Suggestions/ interventions to } \\
\text { reduce MMR }\end{array}$ & \\
\hline
\end{tabular}




\section{Assessment Criteria}

The Polit and Beck (2017) assessment criteria was used to assess and evaluate each article and compare selected research in table format. Qualitative, quantitative and literature reviews were all evaluated. For qualitative and quantitative articles, critiquing questions included analysis of each article’s introduction, method, and discussion as well as general article issues. Literature reviews were evaluated based on thoroughness, article sources, article appraisal, organization, and interpretation.

\section{Cross Study Analysis}

The cross study analysis was completed using a table created by the author (table 3) which allowed for comparison of each article in relation to one another.

Table 3

Cross Study Tables

\begin{tabular}{|c|c|c|}
\hline Title & Key Findings & Recommendations \\
\hline & & \\
\hline
\end{tabular}




\section{Results}

\section{Critique of the Literature}

Fenton, Whitty, and Reynolds (2003; Appendix A-1) performed a prospective observational study of over 8,000 cesarean sections performed in Malawi between 1998 and 2000. Of the 8070 operations evaluated, 85 maternal deaths occurred with an MMR of $1.05 \%$. The problem was clearly identified in the study and key concepts were well defined. Neither a formal literature review nor a theoretical framework were included by the authors. While individual cases were not identified, IRB approval or confidentiality were not addressed. Data were collected using forms distributed to anesthesia providers in 27 of the 35 hospitals that performed cesarean sections in Malawi. The authors minimized bias by not restricting the study to only well-equipped hospitals. Each anesthetist filled completed forms for 20 consecutive cases to minimize selective reporting. The data were analyzed using EpiInfo and Stata 7 and confounding factors were tested. None were found to affect the data for major outcomes.

Statistical significance was included and the findings were well summarized and discussed in the context of the research question. These findings are summarized in Appendix B-1. The level of training of the anesthetist, the amount of blood loss, and the type of anesthesia utilized were identified by the authors as major contributors to the MMR. The discussion addressed modifiable risk factors and need for potential changes in practice. Better resuscitation with fluids was recommended as a relatively safe and inexpensive intervention to be used in the OR and postoperatively when confronted with hemorrhage. Spinal anesthesia over general anesthesia was also shown to be safer, 
assuming no contraindications. Better training in neuraxial technique was needed. Finally, better education and formal training of anesthesia providers was necessary. Also, furthering the education of anesthetists to provide more comprehensive postoperative care in the wards to assist with basic resuscitation could decrease the number of maternal deaths. The work would be translatable to LMICs with similar healthcare demographics.

Glenshaw and Madzimbamuto (2005; Appendix A-2) completed a retrospective study focusing on anesthesia mortality in district hospitals in Zimbabwe between the years of 1994 and 2001. The authors clearly identified the problem in the introduction, but focused primarily on the lack of data and why more data should be collected. The research question, while stated in the abstract, was not explicitly stated in the introduction. The authors did not perform a formal literature review, nor did they identify a theoretical framework. Individual cases were not identified to protect the confidentiality of the patients. While the study sample was well described, the sample size of the study was only 7 and was not based on a power analysis. The sample design only included deaths within 24 hours, but if this had been extended to the international standard of 30 days, the sample size could have been expanded. The authors performed a direct chart review, examining and extracting data that were then summarized. Only one, not both, authors examined the records and reliability and validity was not addressed. Given the small number of participants and the goals of the study, the statistical method was appropriate and a powerful analytic method would not be indicated in this study.

The findings were well summarized, including tables and figures and were discussed in the context of the research question. Of the 77 maternal deaths that occurred during the study period, seven occurred within 24 hours of an anesthetic and five were 
directly attributed to anesthesia. The findings are summarized in Appendix B-2. The deaths attributed to anesthesia were primarily associated with the method of anesthesia, spinal vs general anesthesia; however, the authors postulated that the experience level of the anesthesia provider could have contributed to the maternal deaths. Formally trained anesthesia providers as well as adequate and reliable monitoring devices could decrease the MMR in rural settings.

Enohumah and Imarengiaye (2006; Appendix A-3) reviewed the causes of maternal mortality due to anesthesia in a tertiary hospital in Nigeria between the years of 1991-2000. Their aim was to determine the incidence of maternal morbidity from anesthesia and looked at the specific causes in order to implement changes to improve safety. A retrospective descriptive study was performed, which was appropriate for the study goals. Their findings are presented in Appendix B-3. The purpose of the study and research question were explicitly stated and a brief literature review was included. The process of obstetric anesthesia practice in Nigeria was well defined, including procedures and medications used. Protection of human rights was not addressed; however patient identifiers were not included in the study. The sample was described in detail and the sample design was consistent with international definitions of maternal mortality. The sample size was not based off of a power analysis. Data collection and measurements were described adequately, but it was not addressed if one or both authors reviewed the data. The statistical method utilized was appropriate given the small size of the study. Of all of the patients who died, all of them received general anesthesia and 2/3 died from airway complications. 
The findings, summarized in Appendix B-3, were able to suggest a deficiency in care. A larger study with a more robust sample size would be needed to make broader generalizations EBP. The authors suggested revisiting the practice of using general anesthesia for cesarean section, even when the patient has a number of comorbidities, unless contraindicated. They also emphasized the importance of monitoring as the use of simple monitoring devices could have prevented some of the deaths. Finally, the vigilance of the anesthetist and expertise lead them to suggest a need for an established level of experience, as well as direct supervision for providers in training. The authors did not attempt to generalize to other LMICs and listed this in the limitations section of the study.

Khan et al. (2006; Appendix A-4), completed a systematic review to determine the causes of maternal deaths in light of the key international development goals. The review included all the available literature up to the time the study was completed, with a time limit set to review only recent data. The review included journal articles, registries and published or unpublished information from governments and other agencies, but it was not established if the articles were from peer-reviewed sources. The authors reviewed 34 data sets in the primary analysis to determine the distribution of causes of maternal deaths. The findings are summarized in Appendix B-4. Regional difference existed, with hemorrhage being more prevalent in Africa and Asia and hypertensive disorders as the leading cause of death in Latin America and the Caribbean. By understanding what drives the elevated MMR in various areas, region-specific changes could be implemented. 
Hodges et al. (2007; Appendix A-5), performed a cross-sectional survey that was distributed to anesthesia providers at the national refresher course in Uganda in 2006. By analyzing surveys from providers working in $48 \%$ of the hospitals in Uganda, the authors were able to provide a robust report on the status of anesthesia in the country. The purpose of the study and problem was clearly identified and the research questions and goals were explicitly stated in the introduction. There was not a formal literature review or a theoretical framework. Participant protection or IRB approval was not addressed. The questionnaire utilized was based off of established international guidelines and was piloted and revised prior to administration. The sample size consisted of all the providers at the conference with $\mathrm{N}=97$. A total of $1 / 3$ of the total practicing providers in Uganda were sampled, providing a good representation. Potential bias was present in that only those able to afford to go to the conference or receive time off were given the questionnaires. Qualitative and quantitative data were collected and findings were compiled into tables for review.

The findings are summarized in Appendix B-5. Provider education, necessities for general anesthesia for adults, the status of hospital facilities, ability to perform spinal anesthesia, ability to treat obstetric complications, and availability of drugs were all sources of deficiencies in the provision of safe anesthesia as defined by WFSA international standards. Clinical significance was discussed and deficiencies in obstetric anesthesia and appropriate recommendations were provided. The authors stressed the need for a multifactorial approach on the local, national, and international level to make anesthesia safer and reduce the MMR. 
Ajuzieogu, Ezike, Amucheazi, and Enwereji (2011; Appendix A-6) conducted a retrospective study between the years of 2005-2009 of women with severe preeclampsia requiring cesarean section. The data was collected from the University of Nigeria teaching hospital. The authors provided a clear statement of the problem and research question, an adequate literature review and a sound conceptual underpinning. The method had a well thought out research design; however, the protection of human rights was not addressed. The sample was well described but was not based on a power analysis. Exclusion criteria were well defined. Information addressing maternal age, parity, gestational age at delivery, booking status, APGAR scores, maternal mortality and perinatal mortality was collected. The method in which data was reviewed was not explained and it is unknown if one or all of the authors reviewed the data and how they minimized biases. The method of data analysis was addressed adequately and findings were displayed in tables throughout the article. The patients were classified according to the type of anesthesia they received; either subarachnoid block (group A) or general anesthesia (group B). Statistical significance was defined as $\mathrm{P}<0.05$. The discussion section addressed the implications of the findings, but did not make any recommendations for change in practice.

Findings are summarized in Appendix B-6. The authors reported a noticeable increase in the use of subarachnoid block during their study as compared to previous statistics from studies performed in similar practice environments; however, general anesthesia was still predominately utilized. The authors postulated this could be due to a lack of known safety with the use of subarachnoid block for severe preeclampsia and practitioners have been slower to adopt this method of anesthesia. The findings would be 
translatable to other LMICs with similar healthcare demographics as previous studies have shown similar findings. However, in order for meaningful changes to be made derived from the authors findings, further analysis and discussion would need to be provided.

Anderson et al. (2014; Appendix A-7) performed a review of the literature with the aim of identifying and understanding the components of the anesthesia gap in reproductive health as seen in resource-limited settings. The review was thorough and included a systematic literature search in Medline, the Cochrane Library, CINAHL, Embase, and POPLINE. The search terms were exhaustive and would provide an adequate literature review. All literature was included without a specified time frame which could result in outdated findings, although none of the literature selected for final review was published before 1998. Two reviewers screened the titles and abstracts and included all articles that addressed the study topic. The review relied on primary source research articles, however it was not established if these articles were from peer-reviewed journals. Both authors evaluated the final articles selected for the review. The authors compiled a table summarizing each study and used this to organize and identify three common themes in the literature. Lack of infrastructure, equipment and supplies, and trained personnel all contribute to the MMR in LMICs.

Appendix B-7 includes the specific findings. There did not appear to be a statistical approach to the review, and instead the authors summarized and paraphrased findings within articles. The review highlights the work being doing by the WHO, including the Patient Safety Pulse Oximetry Project and various guides describing minimum essential and equipment and drugs. Clinical significance was discussed and the 
review addressed the risk factors for maternal and perinatal deaths as related to anesthesia in LMICs. The authors recognized the magnitude of the changes required and suggested new and innovative, thinking that is high impact and cost-effective. Because of breadth of this study, findings were generalizable to other LMICs.

Hoyler, Finlayson, McClain, Meara, and Hagander (2014; Appendix A-8) performed a systematic review of literature regarding the number of surgeons, OB/GYNs, and anesthesiologists practicing in LMICs. While the article did not specify a time frame, all but two of the 37 articles included were from between the years of 2003-2012. The review relied on primary source research articles; however, it was not addressed if they were all from peer-reviewed journals. Also, only English-language literature was included, limiting the extent of the search. The authors critically appraised and compared studies and also identified the limitations in existing literature. The authors were able to identify anesthesia workforce shortages by reviewing the available literature. The findings are summarized in Appendix B-88. The article was well organized, objective, and used multiple statistical approaches to support the findings. Clinical significance was discussed and expressed a need for more comprehensive data to help guide improvements in care. More data is required in order to make meaningful proposals that would impact maternal healthcare. By understanding the various causes of the workforce crisis, such as physician migration, recommendations could be made on the national and international level.

Ologunde et al. (2014; Appendix A-9) completed a cross sectional study that assessed the cesarean section delivery availability in 26 LMICs. They justified their study by citing the high MMR in the countries of interest. They did not include a formal 
literature review or a theoretical framework. The Millennium Development goals were defined within the context of this study. Data points were collected by a previous survey conducted by the WHO between 2008 and 2013. Ethical approval was not required as patient records or information were not included. Key variables were measured using statistical analysis and bias minimization was addressed. Chi-square tests were performed and descriptive analysis was used to compare individual elements of the survey. A Pvalue of $<0.05$ was set as statistically significant. The findings are presented in Appendix B-9. Of the 719 facilities included, 531 performed cesarean section. Referral was most common when facilities reported a lack of skills, nonfunctioning equipment, and a paucity of supplies and drugs. The authors reasonably identified the need for improved safety, including achievable actions that may have considerable impacts on surgical capacity, availability of safe access to cesarean section and maternal morbidity and mortality.

Ariyo et al. (2016; Appendix A-10) performed a retrospective analysis of anesthetic procedures performed at Médecins Sans Frontières (MSF) facilities between the years of 2008 and 2014. They reviewed 79,383 anesthetics performed at various MSF mission sites in LMICs to determine what anesthesia equipment and expertise would be required to address the global burden of surgical disease. A clear statement of the problem and goals of the study were provided. A formal literature review was not included but was not necessary to accomplish the aims of this study. The method was well described and addressed the protection of human rights, a detailed research design, and the sample. Even though the sample size was not based off of a power analysis, this was not necessary. Key variables were measured using statistical analysis and a multiple 
regression model. The study used qualified reviewers and biases were limited. The method of data analysis was addressed in detail and findings were displayed in tables.

The findings are presented in Appendix B-10. Spinal anesthesia was found to be performed most frequently and safely and required minimal equipment and monitoring. The discussion section addressed the findings, implication and how they related to the study goal. Specifically, the authors looked at the high burden of obstetric anesthesia and the needs required for adequate maternal care. Also, specialty anesthesia including obstetric/gynecological procedures were associated with a higher risk of mortality, likely due to their lower volume and the lack of expertise of those involved in the case. Thoughtful recommendations were made based on the findings, including the establishment of protocols for perioperative practices and the use of surgery and anesthesia checklists tailored to the unique settings of LMICs. Finally, simplifying anesthesia care by using a basic and conservative list of drugs and procedures can help to create a sustainable and reliable practice that is easily taught and minimizes errors.

Authors Sobhy et al. (2016) performed a systematic review and meta-analysis reviewing anesthesia-related maternal mortality in LMICs with the goal of identifying the factors linked to adverse outcomes. The review included all available studies up to the time of study completion; however, studies completed before 1990 were excluded. The time frame was appropriate given the paucity of data relating directly to anesthesia mortality. The review relied on primary research articles but did not establish if they were peer-reviewed. The study critically appraised and compared data by region and also urban vs. rural settings. A variety of statistic appraisal tools were used to support the author's findings which are presented in Appendix B-11. In the 140 studies included, the 
risk of death attributed to anesthesia was found to be 1.2:1000. General anesthesia, airway failure, and non-physician anesthesia providers without formal training were found to be risk factors for maternal death. Clinical significance was discussed and interpretations were appropriate. Increasing the number of trained providers, education focusing on neuraxial anesthesia, and the availability of basic monitoring equipment could lower the MMR.

Epiu et al. (2017; Appendix A-12) performed a cross-sectional survey assessing the abilities of hospitals in East Africa to provide safe anesthetic care during cesarean section. They analyzed survey results from 85 anesthetists working in 12 obstetric ORs in five national referral hospitals. The authors adequately defined the problem, developed a sound research question, and included a conceptual framework. The literature review and conceptual framework were presented at the end of the study; placing them toward the beginning would have provided better context when reviewing the results. Ethical approval was addressed as well as the research design. The sample was described in detail and the sample size was calculated with a 95\% confidence interval. The principal investigator interviewed the participants and the study procedures were well thought out. Analysis included a strong statistical method and a significance level of $<0.05$ was used.

Findings, which are summarized in Appendix B-12, were well described and could be used in further studies and EBP. Safe anesthetic care was found to be primarily impacted by a number of system and personnel problems, including insufficient or ineffective equipment and poor patient assessment. The authors did attempt to generalize their findings to other LMICs and meaningful changes could be made based on the recommendations from this study. Suggestions included the need for governments to 
ensure there is basic equipment available, investment in training of more physician anesthesiologists, and enhanced supervision of non-physician anesthetists.

\section{Cross-Study Analysis}

When examining the findings together in the cross table (Appendix C), a number of recurring themes emerge. First, the type of anesthesia employed clearly influences the MMR. Five authors including Fenton et al. (2003), Enohumah and Imarengiaye (2006), Ajuzieogu et al. (2011), Ariyo et al. (2016) and Sobhy et al. (2016) reported general anesthesia as a risk factor for maternal death. Some contributing causes include failed airways, inadequate monitoring or equipment, and deficient training of the anesthesia provider. Despite the risks involved, Fenton et al. (2003), Enohumah and Imarengiaye (2006), Ajuzieogu et al. (2011) and Sobhy et al. (2016), report general anesthesia was utilized over spinal anesthesia. Experience of the provider, equipment availability and surgeon comfort were listed as reasons for the preference. Training in spinal anesthesia was a recommendation to improve safety in articles by Fenton et al. (2003), Enohumah and Imarengiaye (2006), and Sobhy et al. (2016).

Availability of basic resources was another common deficiency found by the authors. Seven of the articles by authors Fenton et al. (2003), Glenshaw and Madzimbamuto (2005), Hodges et al. (2007), Anderson et al. (2014), Ologunde et al. (2014), Sobhy et al. (2016), and Epiu et al. (2017) mention a severe lack of pulseoximetry, blood, airway equipment, and medications. Pulse oximetry, for example, was repeatedly reported as a simple yet critical monitoring tool missing from the majority of facilities. Hemorrhage was also reported as a predictor of mortality in six of the articles 
blood availability was hindered by a lack of refrigeration and general infrastructure. Water, electricity, and oxygen were also reported to be inconsistently available. Funding for equipment, development of affordable and reliable monitoring devices, and updating infrastructure were listed as ways to improve anesthetic care.

Training and type of anesthesia provider was also a recurring theme. As found by Hoyler et al., anesthesiologist density is incredibly low in LMICs (2014). Specialists in obstetric anesthesia were found to be to nearly non-existent. Nine of the articles including those by Fenton et al. (2003), Glenshaw and Madzimbamuto (2005), Enohumah and Imarengiaye (2006), Hodges et al. (2007), Anderson et al. (2014), Hoyler et al. (2014), Ologunde et al. (2014), Sobhy et al. (2016) and Epiu et al. (2017), reported a lack of adequately trained personnel impacted patient care. In the absence of physician anesthesiologist, most articles recommended increasing the level of training of nonphysician providers. Also, articles by Ariyo et al. (2016), Sobhy et al. (2016), Epiu et al. (2017), Enohumah and Imarengiaye (2006), and Hodges et al. (2007) mentioned implementing standardized and simplified protocols to help guide practice and reduce errors.

Finally, a lack of research into anesthesia and maternal mortality in LMICs was reported by Khan et al. (2006), Ajuzieogu et al. (2011), Hoyler et al. (2014) and Sobhy et al. (2016). Sobhy et al. even stated there needs to be a standardized global definition and classification of anesthesia-attributed deaths (2016). Comprehensive workforce data, more studies about anesthetic management in LMICs, and increasing capacity for data collection are all necessary to pinpoint specific deficiencies and areas for change. 
Next, the summary and conclusions will be addressed. 


\section{Summary and Conclusions}

While maternal morbidity and mortality has declined due to a number of global initiatives, such as those guided by the Millennium Development Goals, there still remains a unconscionably high rate of demise. As an integral part of the care team, the treatment and actions by anesthetists can make the difference between life or death. While the literature about anesthetic morbidity and mortality in LMICs is somewhat sparse, important themes can be extrapolated. The purpose of this review was to identify these anesthesia-related factors that contribute to the MMR for the parturient, specifically in low-to-middle income countries.

The Three Delays Framework by Thaddeus and Maine (1994) that guided this integrative review allowed the problem of maternal morbidity and mortality to be seen as a multifaceted issue resulting from a series of delays in care. With this framework in mind, an extensive literature search was completed, leading to a final review of 12 articles. Relevant data were synthesized into a table adapted by Anderson et al. (2014), and the analysis method adapted from Polit and Beck (2017) was used to critically evaluate each article. A cross analysis was next performed.

There were a number of limitations to this review. Only English-language articles were able to be evaluated and some articles were translated to English by the authors, resulting in reports that were not always easy to follow, such the article by Glenshaw and Madzimbamuto (2005). Inconsistencies in the definition of a parturient also existed leading to potential exclusion of subjects by some authors. Glenshaw and Madzimbamuto (2005) only included deaths up to 24 hours after delivery where Enohumah and Imarengiaye (2006) included patients up to 30 days after delivery. Also, due to the 
changing global landscape, only articles written within the last 15 years were included, leading to some search restrictions. While some articles had a strong statistical backing with reliable research methods, others were not of the highest quality of research, lacking adequate descriptions of data collection and review. IRB approval or patient protection were not addressed in a number of articles. The cross analysis was not based on a statistical analysis and instead relied on this author's ability to extrapolate findings.

Common emerging themes included the experience of anesthesia providers, the type of anesthesia performed, and the availability of equipment and basic resources. It was found that anesthesia providers without experience specific to obstetrics negatively impacted patient care. Obstetric specialists are practically non-existent in LMICs, so standardization of care and simplified protocols could help to guide practitioners in care. Many countries have difficulty holding onto trained physician anesthesiologists due to medical migration. Creating non-physician anesthetist training programs, modeled after CRNA programs in the United States, could increase local access to proficient anesthetic care.

The use of general anesthesia over spinal anesthesia lead to poorer outcomes for the parturient. Failed intubations and the ultimate respiratory and cardiac arrest of the patient is one major cause of the death from general anesthesia. Of the articles that discussed general vs. spinal anesthesia, all but one by Ariyo et al. (2016) found that general anesthesia was the preferred type of anesthesia used in LMICs. This was due to a lack of education as well cultural acceptance of spinal anesthesia amongst patients and providers. There is also a shortage of medications and spinal needles required to perform the procedures. 
Not only did many authors identify a lack of equipment as a barrier to adequate care, but also there was a lack of basic resources such as electricity or water. Inconsistent access to power, oxygen, or clean water was a reemerging theme throughout this review. The availability of many medications, anesthesia machines, and basic monitoring and airway equipment was also inconsistent across facilities.

In summary, the 12 articles in this integrative review displayed a consistent deficiency in care provided to the parturient, leading to elevated rates of morbidity and mortality in LMICs. However, each article provided tangible recommendations that could ultimately lead to a reduction in the MMR.

Next, the recommendations and implications for advanced practice nursing will be discussed. 


\section{Recommendations and Implications for Advanced Nursing Practice}

This review demonstrated that maternal morbidity and mortality (MMR) in LMICs is an incredibly complex and multifaceted problem. Parturients present to hospitals or clinics, often after traveling long distances, and with minimal prenatal care, arriving as potentially very sick and critical patients for the anesthetist to manage. Some seemingly simple interventions, investments, and changes in practice could lead to better treatment and ultimately reduce the MMR. As experienced, educated, and resourceful providers, CRNAs can play a pivotal role in the transformation of maternal anesthetic care in LMICs.

To be able to properly care for the parturient, basic equipment should be available to the anesthesia provider. Pulse-oximetry is a reliable and easy to use piece of equipment to help assess oxygenation and perfusion. Supporting and implementing programs such as the WHO Pulse Oximetry Project would help to achieve a safer anesthetic. Also, emergency airway equipment such as a battery-powered video laryngoscope could reduce the number of failed intubations. Governments and local organizations need to invest in their health care facilities so there is consistent and reliable access to electricity, oxygen and life-saving equipment and medications. As front-line providers, CRNAs are in the unique position to be able to advocate for their patients and lobby for better resources. Drawing from research and the statistics such as those in this review, anesthetists can make suggestions that will make a tangible difference in the lives of millions.

The establishment of protocols and standards of care, such as those for treating postpartum hemorrhage or emergent cesarean sections, could reduce the MMR by providing basic care guidelines. While the anesthetist should evaluate each patient 
individually, protocols can help direct safe patient care especially in situations where the provider may not have ample experience. Nurse anesthetists, as highly trained providers in the US, could help create these protocols, working with communities and local anesthesia providers to create guidelines that work with the equipment, medications, and resources available.

Anesthesia providers should participate in continuing education and training on new or different techniques and procedures so that they can provide the safest anesthetic to the laboring mother. Spinal anesthesia has consistently been shown to be the safest form of anesthesia for the parturient, yet in LMICs is not routinely utilized and lack of training has been identified as one reason why. Access to books or courses can be limited in many countries, so creating partnerships with providers from other countries is key for continuing education. Nurse anesthetists have extensive training in both spinal and general anesthesia and thus would be great mentors for local anesthetists. Exchange programs, medical missions, online lectures, and simulations are just a few of the ways CRNAs can get involved.

This review has highlighted the need for further research in order to fully understand the reasons for a consistently high rate of maternal death as it relates to anesthesia as well has what changes need to be made to reduce the MMR. Anesthetists play a pivotal role in the care of the parturient and their clinical decisions can make the difference between life and death. Subsequent research should focus on how to best utilize the full scope of practice of non-physician anesthetists in LMICs, how to establish effective and safe treatment guidelines that can be utilized in resource-limited settings, and how to create access to continuing education in remote areas. 
The rate at which women are dying during childbirth is unacceptable in the global society that exists today. Access to medications, equipment, and competent medical treatment should be a universal standard. Greater attention is needed on creating a safer birthing experience, and the role of the anesthetist is a crucial component in the establishment of prudent care. Nurse anesthetists in the United States are an excellent model for cost effective and competent providers who safely function independently. There should be a focus on establishing structured training programs for non-physician anesthesia providers in LMICs, such as those in Nepal and India. Hospitals and governments need to be involved in initiatives such as Safe Surgery Saves Lives and the WHO Pulse Oximetry Project to supply anesthetists with the equipment and tools to create a safer anesthetic experience. While the world has made great strides in reducing the MMR, there is still a long way to go. As CRNAs and integral members of the international healthcare community, it is our duty to do whatever we can to prevent these mothers from dying. 


\section{References}

Ajuzieogu, O. V., Ezike, H. A., Amucheazi, A. O., \& Enwereji, J. (2011). A retrospective study of the outcome of cesarean section for women with severe pre-eclampsia in a third world setting. Saudi J Anaesth, 5(1), 15-18. doi: 10.4103/1658$354 X .76480$

Althabe, F., Sosa, C., Belizan, J. M., Gibbons, L., Jacquerioz, F., \& Bergel, E. (2006). Cesarean section rates and maternal and neonatal mortality in low-, medium-, and high-income countries: an ecological study. Birth, 33(4), 270-277. doi: 10.1111/j.1523-536X.2006.00118.X

American Society of Anesthesiologists. (2016). Practice guidelines for obstetric anesthesia: an updated report by the american society of anesthesiologists task force on obstetric anesthesia and the society for obstetric anesthesia and perinatology. Anesthesiology, 124(2), 270-300. doi:

10.1097/aln.0000000000000935

Anderson, R. E., Ahn, R., Nelson, B. D., Chavez, J., de Redon, E., \& Burke, T. (2014). Defining the anesthesia gap for reproductive health procedures in resource-limited settings. Int J Gynaecol Obstet, 127(3), 229-233. doi: 10.1016/j.ijgo.2014.06.023

Ariyo, P., Trelles, M., Helmand, R., Amir, Y., Hassani, G. H., Mftavyanka, J., . . Latif, A. (2016). Providing anesthesia care in resource-limited settings: A 6-year analysis of anesthesia services provided at Medecins Sans Frontieres facilities. Anesthesiology, 124(3), 561-569. doi: 10.1097/ALN.0000000000000985 
Barnes-Josiah, D., Myntti, C., \& Augustin, A. (1998). The "three delays" as a framework for examining maternal mortality in Haiti. Soc Sci Med, 46(8), 981-993.

Dubowitz, G., Detlefs, S., \& McQueen, K. A. (2010). Global anesthesia workforce crisis: a preliminary survey revealing shortages contributing to undesirable outcomes and unsafe practices. World J Surg, 34(3), 438-444. doi: 10.1007/s00268-0090229-6

Dubowitz, G., \& Evans, F. M. (2012). Developing a curriculum for anaesthesia training in low- and middle-income countries. Best Pract Res Clin Anaesthesiol, 26(1), 1721. doi: 10.1016/j.bpa.2012.02.004

Dyer, R. A., Reed, A. R., \& James, M. F. (2010). Obstetric anaesthesia in low-resource settings. Best Pract Res Clin Obstet Gynaecol, 24(3), 401-412. doi: 10.1016/j.bpobgyn.2009.11.005

Enohumah, K. O., \& Imarengiaye, C. O. (2006). Factors associated with anaesthesiarelated maternal mortality in a tertiary hospital in Nigeria. Acta Anaesthesiol Scand, 50(2), 206-210. doi: 10.1111/j.1399-6576.2006.00945.x

Epiu, I., Tindimwebwa, J. V., Mijumbi, C., Chokwe, T. M., Lugazia, E., Ndarugirire, F., . . Dubowitz, G. (2017). Challenges of anesthesia in low- and middle-income countries: a cross-sectional survey of access to safe obstetric anesthesia in East Africa. Anesth Analg, 124(1), 290-299. doi: 10.1213/ANE.0000000000001690

Fenton, P. M., Whitty, C. J., \& Reynolds, F. (2003). Caesarean section in Malawi: prospective study of early maternal and perinatal mortality. Bmj, 327(7415), 587. doi: $10.1136 / \mathrm{bmj} .327 .7415 .587$ 
Glenshaw, M., \& Madzimbamuto, F. D. (2005). Anaesthesia associated mortality in a district hospital in Zimbabwe: 1994 to 2001. Cent Afr J Med, 51(3-4), 39-44.

Hodges, S. C., Mijumbi, C., Okello, M., McCormick, B. A., Walker, I. A., \& Wilson, I. H. (2007). Anaesthesia services in developing countries: defining the problems. Anaesthesia, 62(1), 4-11. doi: 10.1111/j.1365-2044.2006.04907.x

Hoyler, M., Finlayson, S. R., McClain, C. D., Meara, J. G., \& Hagander, L. (2014). Shortage of doctors, shortage of data: a review of the global surgery, obstetrics, and anesthesia workforce literature. World J Surg, 38(2), 269-280. doi: 10.1007/s00268-013-2324-y

Khan, K. S., Wojdyla, D., Say, L., Gülmezoglu, A. M., \& Van Look, P. F. A. (2006). WHO analysis of causes of maternal death: a systematic review. The Lancet, 367(9516), 1066-1074. doi: 10.1016/s0140-6736(06)68397-9

Livingston, P., Evans, F., Nsereko, E., Nyirigira, G., Ruhato, P., Sargeant, J., . . Enright, A. (2014). Safer obstetric anesthesia through education and mentorship: a model for knowledge translation in Rwanda. Can J Anaesth, 61(11), 1028-1039. doi: $10.1007 / \mathrm{s} 12630-014-0224-8$

Mavalankar, D., \& Sriram, V. (2009). Provision of anaesthesia services for emergency obstetric care through task shifting in South Asia. Reprod Health Matters, 17(33), 21-31. doi: 10.1016/s0968-8080(09)33433-3

Ologunde, R., Vogel, J. P., Cherian, M. N., Sbaiti, M., Merialdi, M., \& Yeats, J. (2014). Assessment of cesarean delivery availability in 26 low- and middle-income countries: a cross-sectional study. Am J Obstet Gynecol, 211(5), 504 e501-504 e512. doi: 10.1016/j.ajog.2014.05.022 
Pacagnella, R. C., Cecatti, J. G., Osis, M. J., \& Souza, J. P. (2012). The role of delays in severe maternal morbidity and mortality: expanding the conceptual framework. Reprod Health Matters, 20(39), 155-163. doi: 10.1016/s0968-8080(12)39601-8

Polit, D., \& Beck, C. T. (2017). Nursing research: Generating and assessing evidence for nursing practice (10th ed.). Philadelphia: Wolters Kluwer.

Ronsmans, C., Holtz, S., \& Stanton, C. (2006). Socioeconomic differentials in caesarean rates in developing countries: a retrospective analysis. The Lancet, 368(9546), 1516-1523. doi: 10.1016/s0140-6736(06)69639-6

Rosseel, P., Trelles, M., Guilavogui, S., Ford, N., \& Chu, K. (2010). Ten years of experience training non-physician anesthesia providers in Haiti. World J Surg, 34(3), 453-458. doi: 10.1007/s00268-009-0192-2

Sobhy, S., Zamora, J., Dharmarajah, K., Arroyo-Manzano, D., Wilson, M., Navaratnarajah, R., . . . Thangaratinam, S. (2016). Anaesthesia-related maternal mortality in low-income and middle-income countries: a systematic review and meta-analysis. The Lancet Global Health, 4(5), e320-e327. doi: 10.1016/s2214$109 x(16) 30003-1$

Thaddeus, S., \& Maine, D. (1994). Too far to walk: maternal mortality in context. Soc Sci Med, 38(8), 1091-1110.

The World Bank. (2015). Maternal mortality ratio (modeled estimate, per 100,000 live births). from http://data.worldbank.org/indicator/SH.STA.MMRT?locations=HT United Nations. (2017). Sustainable Development Goals: Goal 3: Ensure healthy lives and promote well-being for all at all ages. from http://www.un.org/sustainabledevelopment/health/ 
Villar, J., Valladares, E., Wojdyla, D., Zavaleta, N., Carroli, G., Velazco, A., .. . Acosta, A. (2006). Caesarean delivery rates and pregnancy outcomes: the 2005 WHO global survey on maternal and perinatal health in Latin America. Lancet, 367(9525), 1819-1829. doi: 10.1016/s0140-6736(06)68704-7

Vo, D., Cherian, M. N., Bianchi, S., Noel, L., \& Lundeg, G. (2012). Anesthesia Capacity in 22 Low and Middle Income Countries. Journal of Anesthesia \& Clinical Research, 03(04). doi: 10.4172/2155-6148.1000207

World Health Organization. (2006). Taking stock: Task shifting to tackle health worker shortages. Geneva, Switzerland.

World Health Organization. (2013). Global health workforce shortage to reach 12.9 million in coming decades. from http://www.who.int/mediacentre/news/releases/2013/health-workforceshortage/en/

World Health Organization. (2015a). MDG 5: improve maternal health. from http://www.who.int/topics/millennium_development_goals/maternal_health/en/ World Health Organization. (2015b). WHO Statement on Caesarean Section Rates. from http://apps.who.int/iris/bitstream/10665/161442/1/WHO_RHR_15.02_eng.pdf?ua $=1$

World Health Organization. (2016). Surgical workforce reported data by country. Retrieved from: http://apps.who.int/gho/data/node.main.HWF9?lang=en World Health Organization. (2017). Maternal mortality ratio (per 100000 live births). World Health Organization. (2018). Maternal Mortality. from http://www.who.int/en/news-room/fact-sheets/detail/maternal-mortality 


\section{Appendix A-1}

Fenton, P. M., Whitty, C. J., \& Reynolds, F. (2003). Caesarean section in Malawi: prospective study of early maternal and perinatal mortality. Bmj, 327(7415), 587. doi:

10.1136/bmj.327.7415.587

\begin{tabular}{|c|c|c|}
\hline Aspect of the Report & Critiquing Questions & Detailed Critiquing Guidelines \\
\hline Title & $\begin{array}{l}\text { Is the title a good one, } \\
\text { suggesting the key } \\
\text { phenomenon and the group or } \\
\text { community under study? }\end{array}$ & $\begin{array}{l}\text { The title clearly identified the } \\
\text { subject, location, and demographics } \\
\text { of the study. }\end{array}$ \\
\hline Abstract & $\begin{array}{l}\text { Does the abstract clearly and } \\
\text { concisely summarize the main } \\
\text { features of the report? }\end{array}$ & $\begin{array}{l}\text { The abstract outlined all the } \\
\text { components of the study. }\end{array}$ \\
\hline $\begin{array}{l}\text { Introduction } \\
\text { Statement of the } \\
\text { problem }\end{array}$ & $\begin{array}{l}\text { - Was the problem stated } \\
\text { unambiguously and is it easy } \\
\text { to identify? } \\
\text { Did the problem statement } \\
\text { build a cogent and persuasive } \\
\text { argument for the new study? } \\
\text { - Was the problem significant } \\
\text { for nursing? } \\
\text { - Was there a good match } \\
\text { between the research problem } \\
\text { on the one hand and the } \\
\text { paradigm, tradition, and } \\
\text { methods on the other - that is, } \\
\text { was a qualitative approach } \\
\text { appropriate? }\end{array}$ & $\begin{array}{l}\text { The problem was identified clearly } \\
\text { and suggested a need for further } \\
\text { study as there are few published } \\
\text { data on cesarean section in Africa. } \\
\text { The problem is significant for nurse } \\
\text { anesthesia practice as results can } \\
\text { identify deficiencies and potential } \\
\text { areas for change. } \\
\text { A prospective observational study } \\
\text { was appropriate for the study goals } \\
\text { as data can be collected in real time } \\
\text { and problems can be identified as } \\
\text { they occur. }\end{array}$ \\
\hline Research questions & $\begin{array}{l}\text { Were research questions } \\
\text { explicitly stated? If not, was } \\
\text { their absence justified? } \\
\text { Were the questions consistent } \\
\text { with the study’s philosophical } \\
\text { basis, underlying tradition, or } \\
\text { ideologic orientation? }\end{array}$ & $\begin{array}{l}\text { The research question was not } \\
\text { explicitly stated outside of the } \\
\text { abstract. } \\
\text { The question was consistent with } \\
\text { the study's philosophical basis. }\end{array}$ \\
\hline Literature review & $\begin{array}{l}\text { Did the report adequately } \\
\text { summarize the existing body } \\
\text { of knowledge related to the } \\
\text { problem or phenomenon of } \\
\text { interest? } \\
\text { - Did the literature review } \\
\text { provide a strong basis for the } \\
\text { new study? }\end{array}$ & $\begin{array}{l}\text { There was no formal literature } \\
\text { review. }\end{array}$ \\
\hline $\begin{array}{l}\text { Conceptual } \\
\text { underpinnings }\end{array}$ & $\begin{array}{l}\text { Were key concepts adequately } \\
\text { defined conceptually? } \\
\text { Was the philosophical basis, } \\
\text { underlying tradition, } \\
\text { conceptual framework, or } \\
\text { ideologic orientation made } \\
\text { explicit and was it appropriate } \\
\text { for the problem? }\end{array}$ & $\begin{array}{l}\text { Maternal mortality was defined in } \\
\text { the introduction. }\end{array}$ \\
\hline
\end{tabular}




\begin{tabular}{|c|c|c|}
\hline $\begin{array}{l}\text { Conceptual/theoretical } \\
\text { framework }\end{array}$ & $\begin{array}{l}\text { - Were key concepts adequately } \\
\text { defined conceptually? } \\
\text { - Was a conceptual/theoretical } \\
\text { framework articulated-and, if } \\
\text { so, was it appropriate? If not, } \\
\text { is the absence of a framework } \\
\text { justified? } \\
\text { - Were the questions/hypotheses } \\
\text { consistent with the framework? }\end{array}$ & $\begin{array}{l}\text { There was no theoretical framework } \\
\text { identified which seemed appropriate } \\
\text { for this type of study. }\end{array}$ \\
\hline $\begin{array}{l}\text { Method } \\
\text { Protection of human } \\
\text { rights }\end{array}$ & $\begin{array}{l}\text { - Were appropriate procedures } \\
\text { used to safe-guard the rights of } \\
\text { study participants? } \\
\text { - Was the study externally } \\
\text { reviewed by an IRB/ethics } \\
\text { review board? } \\
\text { - Was the study designed to } \\
\text { minimize risks and maximize } \\
\text { benefits to participants? }\end{array}$ & $\begin{array}{l}\text { Individual cases were not identified } \\
\text { to protect patient and physician } \\
\text { confidentiality. } \\
\text { IRB approval was not addressed by } \\
\text { the authors. }\end{array}$ \\
\hline Research design & $\begin{array}{l}\text { Was the most rigorous design } \\
\text { used, given the study purpose? } \\
\text { Were appropriate comparisons } \\
\text { made to enhance } \\
\text { interpretability of the findings? } \\
\text { - Was the number of data } \\
\text { collection points appropriate? } \\
\text { Did the design minimize biases } \\
\text { and threats to the internal, } \\
\text { construct, and external validity } \\
\text { of the study (e.g., was blinding } \\
\text { used, was attrition } \\
\text { minimized)? }\end{array}$ & $\begin{array}{l}\text { A prospective observational was is } \\
\text { appropriate for the study goals. Data } \\
\text { was collected from a wide range of } \\
\text { hospitals in the country within a } 2 \\
\text { year time frame leading to over } \\
8000 \text { operations. } \\
\text { The data forms used provided the } \\
\text { authors with sufficient data that was } \\
\text { relevant to their study. } \\
\text { Data was excluded due to } \\
\text { inaccuracies, invalidities or } \\
\text { inconsistencies as determined by the } \\
\text { authors. }\end{array}$ \\
\hline $\begin{array}{l}\text { Population and } \\
\text { sample }\end{array}$ & $\begin{array}{l}\text { Was the population identified? } \\
\text { Was the sample described in } \\
\text { sufficient detail? } \\
\text { Was the best possible sampling } \\
\text { design used to enhance the } \\
\text { sample's representativeness? } \\
\text { Were sampling biases } \\
\text { minimized? } \\
\text { Was the sample size based on } \\
\text { a power analysis? }\end{array}$ & $\begin{array}{l}\text { The population was adequately } \\
\text { identified and described in detail. } \\
\text { The sample size was not based on a } \\
\text { power analysis. }\end{array}$ \\
\hline $\begin{array}{l}\text { Data collection and } \\
\text { measurement }\end{array}$ & $\begin{array}{l}\text { - Were the operational and } \\
\text { conceptual definitions } \\
\text { congruent? } \\
\text { Were key variables measured } \\
\text { using an appropriate method } \\
\text { (e.g., interviews, observations, } \\
\text { and so on)? } \\
\text { Were specific instruments } \\
\text { adequately described and were } \\
\text { they good choices, given the } \\
\text { study population and the } \\
\text { variables being studied? } \\
\text { Did the report provide } \\
\text { evidence that the data }\end{array}$ & $\begin{array}{l}\text { The authors performed the study } \\
\text { how they conceptualized it. } \\
\text { Key variables were measured. } \\
\text { The method in which the findings } \\
\text { were analyzed was well described. }\end{array}$ \\
\hline
\end{tabular}




\begin{tabular}{|c|c|c|}
\hline & $\begin{array}{l}\text { collection methods yielded } \\
\text { data that were reliable, valid } \\
\text { and responsive? }\end{array}$ & \\
\hline Procedures & $\begin{array}{l}\text { If there was an intervention, } \\
\text { was it adequately described, } \\
\text { and was it rigorously } \\
\text { developed and implemented? } \\
\text { Did most participants allocated } \\
\text { to the intervention group } \\
\text { actually receive it? Was there } \\
\text { evidence of intervention } \\
\text { fidelity? } \\
\text { Were data collected in a } \\
\text { manner that minimized bias? } \\
\text { Were the staff who collected } \\
\text { data appropriately trained? }\end{array}$ & $\begin{array}{l}\text { Bias was minimized by not } \\
\text { restricting the study to only well- } \\
\text { equipped hospitals. }\end{array}$ \\
\hline Data Analysis & $\begin{array}{l}\text { - Were analyses undertaken to } \\
\text { address each research question } \\
\text { or test each hypothesis? } \\
\text { Were appropriate statistical } \\
\text { methods used, given the level } \\
\text { of measurement of the } \\
\text { variables, number of groups } \\
\text { being compared, and } \\
\text { assumptions of the texts? } \\
\text { Was a powerful analytic } \\
\text { method used? (e.g., did the } \\
\text { analysis help to control for } \\
\text { confounding variables)? } \\
\text { Were type I and Type II errors } \\
\text { avoided or minimized? } \\
\text { In intervention studies, was an } \\
\text { intention-to-treat analysis } \\
\text { performed? } \\
\text { Were problems of missing } \\
\text { values evaluated and } \\
\text { adequately addressed? }\end{array}$ & $\begin{array}{l}\text { The data was well analyzed to } \\
\text { address the research questions. } \\
\text { The statistical method was } \\
\text { appropriate using EpiInfo and Stata } \\
7 \text { for analysis. Confounding factors } \\
\text { were tested and none were found to } \\
\text { affect the data for major outcomes. } \\
\text { A powerful analytic method was } \\
\text { used and errors were minimized. }\end{array}$ \\
\hline Findings & $\begin{array}{l}\text { Was information about } \\
\text { statistical significance } \\
\text { presented? Was information } \\
\text { about effect size and precision } \\
\text { of estimates (confidence } \\
\text { intervals) presented? } \\
\text { Were the findings adequately } \\
\text { summarized, with good use of } \\
\text { tables and figures? } \\
\text { Were findings reported in a } \\
\text { manner that facilitates a meta- } \\
\text { analysis, and with sufficient } \\
\text { information needed for EBP? }\end{array}$ & $\begin{array}{l}\text { Statistical significance was } \\
\text { included. } \\
\text { The findings were well summarized } \\
\text { including tables and figures. } \\
\text { The findings suggested the need for } \\
\text { further studies but did not elicit } \\
\text { specific change. }\end{array}$ \\
\hline $\begin{array}{l}\text { Discussion } \\
\text { Interpretation of the } \\
\text { findings }\end{array}$ & $\begin{array}{l}\text { Were all major findings } \\
\text { interpreted and discussed } \\
\text { within the context of prior } \\
\text { research and/or the study’s } \\
\text { conceptual framework? }\end{array}$ & $\begin{array}{l}\text { The findings were discussed in the } \\
\text { context of the research questions. } \\
\text { Casual inferences were made and } \\
\text { justified given the results of the } \\
\text { study. }\end{array}$ \\
\hline
\end{tabular}




\begin{tabular}{|c|c|c|}
\hline & $\begin{array}{l}\text { Were casual inferences, if any, } \\
\text { justified? } \\
\text { Was the issue of clinical } \\
\text { significance discussed? } \\
\text { Were interpretations well- } \\
\text { founded and consistent with } \\
\text { the study's limitations? } \\
\text { - Did the report address the issue } \\
\text { of the generalizability of the } \\
\text { findings? }\end{array}$ & $\begin{array}{l}\text { Clinical significance was discussed } \\
\text { and interpretations were generally } \\
\text { appropriate. } \\
\text { The study did attempt to generalize } \\
\text { its findings to other LMICs. }\end{array}$ \\
\hline $\begin{array}{l}\text { Implications/ } \\
\text { recommendations }\end{array}$ & $\begin{array}{l}\text { Did the researchers discuss the } \\
\text { implications of the study for } \\
\text { clinical practice or further } \\
\text { research-and were those } \\
\text { implications reasonable and } \\
\text { complete? }\end{array}$ & $\begin{array}{l}\text { The authors reasonably identified } \\
\text { the need for improved safety, } \\
\text { including achievable actions that } \\
\text { may have considerable impacts on } \\
\text { maternal morbidity and mortality. }\end{array}$ \\
\hline $\begin{array}{l}\text { General Issues } \\
\text { Presentation }\end{array}$ & $\begin{array}{l}\text { Was the report well-written, } \\
\text { organized, and sufficiently } \\
\text { detailed for critical analysis? } \\
\text { Was the report written in a } \\
\text { manner that makes the findings } \\
\text { accessible to practicing nurses? }\end{array}$ & $\begin{array}{l}\text { The report was easy to follow and } \\
\text { was well organized. Subheadings } \\
\text { were an effective way to outline the } \\
\text { data. }\end{array}$ \\
\hline Researcher credibility & $\begin{array}{l}\text { Do the researchers' clinical, } \\
\text { substantive, or methodologic } \\
\text { qualifications and experience } \\
\text { enhance confidence in the } \\
\text { findings and their } \\
\text { interpretation? }\end{array}$ & $\begin{array}{l}\text { There was information about the } \\
\text { author's qualifications and } \\
\text { experience. }\end{array}$ \\
\hline Summary assessment & $\begin{array}{l}\text { Despite any limitations, do the } \\
\text { study findings appear to be } \\
\text { valid—do you have confidence } \\
\text { in the truth value of the } \\
\text { results? } \\
\text { - Does the study contribute any } \\
\text { meaningful evidence that can } \\
\text { be used in nursing practice or } \\
\text { that is useful to the nursing } \\
\text { discipline? }\end{array}$ & $\begin{array}{l}\text { The study findings appear to be } \\
\text { valid and translatable to other } \\
\text { LMICs with similar healthcare } \\
\text { demographics. } \\
\text { Meaningful changes can be made } \\
\text { based off of the recommendations } \\
\text { of this study. }\end{array}$ \\
\hline
\end{tabular}




\section{Appendix A-2}

Glenshaw, M., \& Madzimbamuto, F. D. (2005). Anaesthesia associated mortality in a district hospital in Zimbabwe: 1994 to 2001. Cent Afr J Med, 51(3-4), 39-44.

\begin{tabular}{|c|c|c|}
\hline Aspect of the Report & Critiquing Questions & Detailed Critiquing Guidelines \\
\hline Title & $\begin{array}{l}\text { Is the title a good one, } \\
\text { suggesting the key } \\
\text { phenomenon and the group or } \\
\text { community under study? }\end{array}$ & $\begin{array}{l}\text { The title clearly identified the } \\
\text { subject, location, and time frame of } \\
\text { the study. }\end{array}$ \\
\hline Abstract & $\begin{array}{l}\text { Does the abstract clearly and } \\
\text { concisely summarize the main } \\
\text { features of the report? }\end{array}$ & $\begin{array}{l}\text { The abstract outlined all the } \\
\text { components of the study. }\end{array}$ \\
\hline $\begin{array}{l}\text { Introduction } \\
\text { Statement of the } \\
\text { problem }\end{array}$ & $\begin{array}{l}\text { Was the problem stated } \\
\text { unambiguously and is it easy } \\
\text { to identify? } \\
\text { Did the problem statement } \\
\text { build a cogent and persuasive } \\
\text { argument for the new study? } \\
\text { Was the problem significant } \\
\text { for nursing? } \\
\text { Was there a good match } \\
\text { between the research problem } \\
\text { on the one hand and the } \\
\text { paradigm, tradition, and } \\
\text { methods on the other - that is, } \\
\text { was a qualitative approach } \\
\text { appropriate? }\end{array}$ & $\begin{array}{l}\text { The problem was identified clearly } \\
\text { and suggests a need for further } \\
\text { study. However, the introduction } \\
\text { focused on the lack of data and not } \\
\text { why more data should be collected. } \\
\text { The problem is significant for } \\
\text { nursing anesthesia practice as results } \\
\text { can identify deficiencies and } \\
\text { potential areas for change. } \\
\text { A retrospective descriptive study } \\
\text { was appropriate for the study goals. } \\
\text { Reviewing previous records without } \\
\text { implementing a change allowed for } \\
\text { identification of existing problems. }\end{array}$ \\
\hline Research questions & $\begin{array}{l}\text { Were research questions } \\
\text { explicitly stated? If not, was } \\
\text { their absence justified? } \\
\text { Were the questions consistent } \\
\text { with the study's philosophical } \\
\text { basis, underlying tradition, or } \\
\text { ideologic orientation? }\end{array}$ & $\begin{array}{l}\text { The research question was not } \\
\text { explicitly stated outside of the } \\
\text { abstract. } \\
\text { The question was consistent with the } \\
\text { study's philosophical basis. }\end{array}$ \\
\hline Literature review & $\begin{array}{l}\text { Did the report adequately } \\
\text { summarize the existing body } \\
\text { of knowledge related to the } \\
\text { problem or phenomenon of } \\
\text { interest? } \\
\text { - Did the literature review } \\
\text { provide a strong basis for the } \\
\text { new study? }\end{array}$ & $\begin{array}{l}\text { There was no formal literature } \\
\text { review. } \\
\text { A similar study was mentioned in } \\
\text { the introduction. }\end{array}$ \\
\hline $\begin{array}{l}\text { Conceptual } \\
\text { underpinnings }\end{array}$ & $\begin{array}{l}\text { Were key concepts adequately } \\
\text { defined conceptually? } \\
\text { Was the philosophical basis, } \\
\text { underlying tradition, } \\
\text { conceptual framework, or } \\
\text { ideologic orientation made } \\
\text { explicit and was it appropriate } \\
\text { for the problem? }\end{array}$ & $\begin{array}{l}\text { The anesthetic practice during the } \\
\text { period of this study was reviewed } \\
\text { allowing for a definition of key } \\
\text { concepts. }\end{array}$ \\
\hline
\end{tabular}




\begin{tabular}{|c|c|c|}
\hline $\begin{array}{l}\text { Conceptual/theoretical } \\
\text { framework }\end{array}$ & $\begin{array}{l}\text { - Were key concepts adequately } \\
\text { defined conceptually? } \\
\text { Was a conceptual/theoretical } \\
\text { framework articulated-and, } \\
\text { if so, was it appropriate? If } \\
\text { not, is the absence of a } \\
\text { framework justified? } \\
\text { - Were the } \\
\text { questions/hypotheses } \\
\text { consistent with the } \\
\text { framework? }\end{array}$ & $\begin{array}{l}\text { There was no theoretical framework } \\
\text { identified which seemed appropriate } \\
\text { for this type of study. }\end{array}$ \\
\hline $\begin{array}{l}\text { Method } \\
\text { Protection of human } \\
\text { rights }\end{array}$ & $\begin{array}{l}\text { - Were appropriate procedures } \\
\text { used to safe-guard the rights } \\
\text { of study participants? } \\
\text { Was the study externally } \\
\text { reviewed by an IRB/ethics } \\
\text { review board? } \\
\text { - Was the study designed to } \\
\text { minimize risks and maximize } \\
\text { benefits to participants? }\end{array}$ & $\begin{array}{l}\text { Individual cases not identified to } \\
\text { protect patient and physician } \\
\text { confidentiality. } \\
\text { The authors did not address if the } \\
\text { study was IRB approved. }\end{array}$ \\
\hline Research design & $\begin{array}{l}\text { - Was the most rigorous design } \\
\text { used, given the study purpose? } \\
\text { Were appropriate comparisons } \\
\text { made to enhance } \\
\text { interpretability of the } \\
\text { findings? } \\
\text { - Was the number of data } \\
\text { collection points appropriate? } \\
\text { Did the design minimize } \\
\text { biases and threats to the } \\
\text { internal, construct, and } \\
\text { external validity of the study } \\
\text { (e.g., was blinding used, was } \\
\text { attrition minimized)? }\end{array}$ & $\begin{array}{l}\text { A retrospective descriptive study } \\
\text { was appropriate for the study goals. } \\
\text { The authors made appropriate } \\
\text { comparisons in the data collected, } \\
\text { however a broader study would have } \\
\text { enhanced the credibility of the } \\
\text { findings. This could be achieved by } \\
\text { either expanding the study } \\
\text { timeframe or reviewing cases from } \\
\text { other regional hospitals. } \\
\text { Selection bias was minimized as all } \\
\text { deaths were analyzed. }\end{array}$ \\
\hline $\begin{array}{l}\text { Population and } \\
\text { sample }\end{array}$ & $\begin{array}{l}\text { Was the population identified? } \\
\text { Was the sample described in } \\
\text { sufficient detail? } \\
\text { Was the best possible } \\
\text { sampling design used to } \\
\text { enhance the sample's } \\
\text { representativeness? Were } \\
\text { sampling biases minimized? } \\
\text { Was the sample size based on } \\
\text { a power analysis? }\end{array}$ & $\begin{array}{l}\text { The population was adequately } \\
\text { identified and described in great } \\
\text { detail including common } \\
\text { characteristics and socioeconomic } \\
\text { status. } \\
\text { The sample design only included } \\
\text { deaths within } 24 \text { hours of receiving } \\
\text { an anesthetic. This could have been } \\
\text { extended to } 30 \text { days, the } \\
\text { international standard. } \\
\text { The sample size was not based on a } \\
\text { power analysis and included all } \\
\text { patients who had died. The size of } \\
\text { the sample was small (n=7). }\end{array}$ \\
\hline $\begin{array}{l}\text { Data collection and } \\
\text { measurement }\end{array}$ & $\begin{array}{l}\text { - Were the operational and } \\
\text { conceptual definitions } \\
\text { congruent? } \\
\text { - Were key variables measured } \\
\text { using an appropriate method }\end{array}$ & $\begin{array}{l}\text { The authors performed the study } \\
\text { how they conceptualized it. } \\
\text { Key variables were measured by } \\
\text { direct chart review which is } \\
\text { appropriate for this study. It was not }\end{array}$ \\
\hline
\end{tabular}




\begin{tabular}{|c|c|c|}
\hline & $\begin{array}{l}\text { (e.g., interviews, observations, } \\
\text { and so on)? } \\
\text { Were specific instruments } \\
\text { adequately described and were } \\
\text { they good choices, given the } \\
\text { study population and the } \\
\text { variables being studied? } \\
\text { Did the report provide } \\
\text { evidence that the data } \\
\text { collection methods yielded } \\
\text { data that were reliable, valid } \\
\text { and responsive? }\end{array}$ & $\begin{array}{l}\text { addressed if the author's developed } \\
\text { their own data collection tables. } \\
\text { The method in which the findings } \\
\text { were analyzed was well described. } \\
\text { The report did not provide evidence } \\
\text { that data collection was valid or } \\
\text { reliable. }\end{array}$ \\
\hline Procedures & $\begin{array}{l}\text { If there was an intervention, } \\
\text { was it adequately described, } \\
\text { and was it rigorously } \\
\text { developed and implemented? } \\
\text { Did most participants } \\
\text { allocated to the intervention } \\
\text { group actually receive it? } \\
\text { Was there evidence of } \\
\text { intervention fidelity? } \\
\text { Were data collected in a } \\
\text { manner that minimized bias? } \\
\text { Were the staff who collected } \\
\text { data appropriately trained? }\end{array}$ & $\begin{array}{l}\text { One of the authors examined the } \\
\text { records and extracted and } \\
\text { summarized data. It may have been } \\
\text { more appropriate for both authors to } \\
\text { look at each record and synthesize } \\
\text { their findings. }\end{array}$ \\
\hline Data Analysis & $\begin{array}{l}\text { - Were analyses undertaken to } \\
\text { address each research question } \\
\text { or test each hypothesis? } \\
\text { Were appropriate statistical } \\
\text { methods used, given the level } \\
\text { of measurement of the } \\
\text { variables, number of groups } \\
\text { being compared, and } \\
\text { assumptions of the texts? } \\
\text { Was a powerful analytic } \\
\text { method used? (e.g., did the } \\
\text { analysis help to control for } \\
\text { confounding variables)? } \\
\text { Were type I and Type II errors } \\
\text { avoided or minimized? } \\
\text { In intervention studies, was an } \\
\text { intention-to-treat analysis } \\
\text { performed? } \\
\text { Were problems of missing } \\
\text { values evaluated and } \\
\text { adequately addressed? }\end{array}$ & $\begin{array}{l}\text { The data was well analyzed to } \\
\text { address the research question. } \\
\text { The statistical method was } \\
\text { appropriate given the small number } \\
\text { of cases studied and the goals of the } \\
\text { authors. } \\
\text { A powerful analytic method was not } \\
\text { used and errors were not minimized, } \\
\text { but would not be indicated in } \\
\text { accordance to the study's goals. }\end{array}$ \\
\hline Findings & $\begin{array}{l}\text { - Was information about } \\
\text { statistical significance } \\
\text { presented? Was information } \\
\text { about effect size and precision } \\
\text { of estimates (confidence } \\
\text { intervals) presented? } \\
\text { - Were the findings adequately } \\
\text { summarized, with good use of } \\
\text { tables and figures? }\end{array}$ & $\begin{array}{l}\text { No statistical significance was } \\
\text { included. } \\
\text { The findings were well summarized } \\
\text { including tables and figures. } \\
\text { The findings suggested the need for } \\
\text { further studies but did not make } \\
\text { specific recommendations. }\end{array}$ \\
\hline
\end{tabular}




\begin{tabular}{|c|c|c|}
\hline & $\begin{array}{l}\text { Were findings reported in a } \\
\text { manner that facilitates a meta- } \\
\text { analysis, and with sufficient } \\
\text { information needed for EBP? }\end{array}$ & \\
\hline $\begin{array}{l}\text { Discussion } \\
\text { Interpretation of the } \\
\text { findings }\end{array}$ & $\begin{array}{l}\text { - Were all major findings } \\
\text { interpreted and discussed } \\
\text { within the context of prior } \\
\text { research and/or the study's } \\
\text { conceptual framework? } \\
\text { - Were casual inferences, if } \\
\text { any, justified? } \\
\text { - Was the issue of clinical } \\
\text { significance discussed? } \\
\text { Were interpretations well- } \\
\text { founded and consistent with } \\
\text { the study’s limitations? } \\
\text { Did the report address the } \\
\text { issue of the generalizability of } \\
\text { the findings? }\end{array}$ & $\begin{array}{l}\text { The findings were discussed in the } \\
\text { context of the research question. } \\
\text { Casual inferences were made and } \\
\text { justified given the results of the } \\
\text { study. } \\
\text { Clinical significance was discussed } \\
\text { and interpretations were generally } \\
\text { appropriate given the limitation of } \\
\text { the study. } \\
\text { The study did attempt to generalize } \\
\text { its findings to other LMICs. }\end{array}$ \\
\hline $\begin{array}{l}\text { Implications/ } \\
\text { recommendations }\end{array}$ & $\begin{array}{l}\text { Did the researchers discuss } \\
\text { the implications of the study } \\
\text { for clinical practice or further } \\
\text { research-and were those } \\
\text { implications reasonable and } \\
\text { complete? }\end{array}$ & $\begin{array}{l}\text { The authors reasonably identified the } \\
\text { need for further study into anesthetic } \\
\text { deaths in rural hospitals. }\end{array}$ \\
\hline $\begin{array}{l}\text { General Issues } \\
\text { Presentation }\end{array}$ & $\begin{array}{l}\text { Was the report well-written, } \\
\text { organized, and sufficiently } \\
\text { detailed for critical analysis? } \\
\text { Was the report written in a } \\
\text { manner that makes the } \\
\text { findings accessible to } \\
\text { practicing nurses? }\end{array}$ & $\begin{array}{l}\text { The report was not always easy to } \\
\text { follow which could be due to } \\
\text { translation. The study could have } \\
\text { been organized better, clearly } \\
\text { outlining how data was reviewed and } \\
\text { analyzed. }\end{array}$ \\
\hline Researcher credibility & $\begin{array}{l}\text { Do the researchers' clinical, } \\
\text { substantive, or methodologic } \\
\text { qualifications and experience } \\
\text { enhance confidence in the } \\
\text { findings and their } \\
\text { interpretation? }\end{array}$ & $\begin{array}{l}\text { There was little information about } \\
\text { the author's qualifications and } \\
\text { experience- only a small footnote. }\end{array}$ \\
\hline Summary assessment & $\begin{array}{l}\text { - Despite any limitations, do the } \\
\text { study findings appear to be } \\
\text { valid-do you have } \\
\text { confidence in the truth value } \\
\text { of the results? } \\
\text { Does the study contribute any } \\
\text { meaningful evidence that can } \\
\text { be used in nursing practice or } \\
\text { that is useful to the nursing } \\
\text { discipline? }\end{array}$ & $\begin{array}{l}\text { Statistical significance of the results } \\
\text { was not addressed and the study size } \\
\text { was limited, so results should be } \\
\text { considered cautiously. } \\
\text { The study identified a problem and } \\
\text { shows a need for further research on } \\
\text { a larger scale. }\end{array}$ \\
\hline
\end{tabular}




\section{Appendix A-3}

Enohumah, K. O., \& Imarengiaye, C. O. (2006). Factors associated with anaesthesia-related maternal mortality in a tertiary hospital in Nigeria. Acta Anaesthesiol Scand, 50(2), 206-210. doi: 10.1111/j.1399-6576.2006.00945.x

\begin{tabular}{|c|c|c|}
\hline Aspect of the Report & Critiquing Questions & Detailed Critiquing Guidelines \\
\hline Title & $\begin{array}{l}\text { Is the title a good one, } \\
\text { suggesting the key } \\
\text { phenomenon and the group or } \\
\text { community under study? }\end{array}$ & $\begin{array}{l}\text { The title clearly identified the } \\
\text { subject, location, and demographics } \\
\text { of the study. }\end{array}$ \\
\hline Abstract & $\begin{array}{l}\text { Does the abstract clearly and } \\
\text { concisely summarize the main } \\
\text { features of the report? }\end{array}$ & $\begin{array}{l}\text { The abstract outlined all the } \\
\text { components of the study. }\end{array}$ \\
\hline $\begin{array}{l}\text { Introduction } \\
\text { Statement of the } \\
\text { problem }\end{array}$ & $\begin{array}{l}\text { Was the problem stated } \\
\text { unambiguously and is it easy } \\
\text { to identify? } \\
\text { Did the problem statement } \\
\text { build a cogent and persuasive } \\
\text { argument for the new study? } \\
\text { - Was the problem significant } \\
\text { for nursing? } \\
\text { Was there a good match } \\
\text { between the research problem } \\
\text { on the one hand and the } \\
\text { paradigm, tradition, and } \\
\text { methods on the other - that is, } \\
\text { was a qualitative approach } \\
\text { appropriate? }\end{array}$ & $\begin{array}{l}\text { The problem was identified clearly } \\
\text { and thoroughly and suggests a need } \\
\text { for further study. } \\
\text { The problem is significant for } \\
\text { nursing anesthesia practice as } \\
\text { results can identify deficiencies and } \\
\text { potential areas for change. } \\
\text { A retrospective descriptive study } \\
\text { was appropriate for the study goals. } \\
\text { Reviewing previous records without } \\
\text { implementing a change allows for } \\
\text { identification of existing problems. }\end{array}$ \\
\hline Research questions & $\begin{array}{l}\text { - Were research questions } \\
\text { explicitly stated? If not, was } \\
\text { their absence justified? } \\
\text { - Were the questions consistent } \\
\text { with the study's philosophical } \\
\text { basis, underlying tradition, or } \\
\text { ideologic orientation? }\end{array}$ & $\begin{array}{l}\text { The purpose of the study and } \\
\text { research question were explicitly } \\
\text { stated at the end of the introduction. } \\
\text { The question was consistent with } \\
\text { the study's philosophical basis. }\end{array}$ \\
\hline Literature review & $\begin{array}{l}\text { Did the report adequately } \\
\text { summarize the existing body of } \\
\text { knowledge related to the } \\
\text { problem or phenomenon of } \\
\text { interest? } \\
\text { - Did the literature review } \\
\text { provide a strong basis for the } \\
\text { new study? }\end{array}$ & $\begin{array}{l}\text { A brief literature review was } \\
\text { included in the beginning of the } \\
\text { study of the study and tied in other } \\
\text { literature to the topic of this study } \\
\text { well. It also provided a strong basis } \\
\text { for the new study, identifying } \\
\text { anesthesia as an emerging risk } \\
\text { factor of concern. }\end{array}$ \\
\hline $\begin{array}{l}\text { Conceptual } \\
\text { underpinnings }\end{array}$ & $\begin{array}{l}\text { Were key concepts adequately } \\
\text { defined conceptually? } \\
\text { Was the philosophical basis, } \\
\text { underlying tradition, } \\
\text { conceptual framework, or } \\
\text { ideologic orientation made } \\
\text { explicit and was it appropriate } \\
\text { for the problem? }\end{array}$ & $\begin{array}{l}\text { The process of obstetric anesthesia } \\
\text { practice in Nigeria was well defined } \\
\text { in the "Patients and Methods" } \\
\text { section and was appropriate for the } \\
\text { problem. }\end{array}$ \\
\hline $\begin{array}{l}\text { Conceptual/theoretical } \\
\text { framework }\end{array}$ & $\begin{array}{l}\text { Were key concepts adequately } \\
\text { defined conceptually? }\end{array}$ & $\begin{array}{l}\text { There was not a theoretical } \\
\text { framework referenced in this study. }\end{array}$ \\
\hline
\end{tabular}




\begin{tabular}{|c|c|c|}
\hline & $\begin{array}{l}\text { - Was a conceptual/theoretical } \\
\text { framework articulated-and, if } \\
\text { so, was it appropriate? If not, } \\
\text { is the absence of a framework } \\
\text { justified? } \\
\text { - Were the questions/hypotheses } \\
\text { consistent with the framework? }\end{array}$ & \\
\hline $\begin{array}{l}\text { Method } \\
\text { Protection of human } \\
\text { rights }\end{array}$ & $\begin{array}{l}\text { - Were appropriate procedures } \\
\text { used to safe-guard the rights of } \\
\text { study participants? } \\
\text { - Was the study externally } \\
\text { reviewed by an IRB/ethics } \\
\text { review board? } \\
\text { - Was the study designed to } \\
\text { minimize risks and maximize } \\
\text { benefits to participants? }\end{array}$ & $\begin{array}{l}\text { This was not addressed, but no } \\
\text { identifiers were included in the } \\
\text { reporting of the study. }\end{array}$ \\
\hline Research design & $\begin{array}{l}\text { Was the most rigorous design } \\
\text { used, given the study purpose? } \\
\text { Were appropriate comparisons } \\
\text { made to enhance } \\
\text { interpretability of the findings? } \\
\text { - Was the number of data } \\
\text { collection points appropriate? } \\
\text { Did the design minimize biases } \\
\text { and threats to the internal, } \\
\text { construct, and external validity } \\
\text { of the study (e.g., was blinding } \\
\text { used, was attrition minimized)? }\end{array}$ & $\begin{array}{l}\text { A retrospective descriptive study } \\
\text { was appropriate for the study goals. } \\
\text { The length of time data was studied } \\
\text { was appropriate as it allowed for a } \\
\text { large number of deliveries to be } \\
\text { studied. } \\
\text { The authors reviewed all sources of } \\
\text { records that would contribute to this } \\
\text { study. }\end{array}$ \\
\hline $\begin{array}{l}\text { Population and } \\
\text { sample }\end{array}$ & $\begin{array}{l}\text { - Was the population identified? } \\
\text { Was the sample described in } \\
\text { sufficient detail? } \\
\text { - Was the best possible sampling } \\
\text { design used to enhance the } \\
\text { sample's representativeness? } \\
\text { Were sampling biases } \\
\text { minimized? } \\
\text { - Was the sample size based on a } \\
\text { power analysis? }\end{array}$ & $\begin{array}{l}\text { The population was adequately } \\
\text { identified and described in detail } \\
\text { including common characteristics } \\
\text { and socioeconomic status. } \\
\text { The sample design was consistent } \\
\text { with the internationally accepted } \\
\text { definition of maternal mortality: } \\
\text { death while pregnant or within } 42 \\
\text { days of termination of pregnancy. } \\
\text { Women also who died during a } \\
\text { cervical cerclage procedure were } \\
\text { included along with cesarean } \\
\text { section. } \\
\text { The sample size was not based on a } \\
\text { power analysis and included all } \\
\text { patients who had died from } \\
\text { anesthesia-related complications. }\end{array}$ \\
\hline $\begin{array}{l}\text { Data collection and } \\
\text { measurement }\end{array}$ & $\begin{array}{l}\text { - Were the operational and } \\
\text { conceptual definitions } \\
\text { congruent? } \\
\text { Were key variables measured } \\
\text { using an appropriate method } \\
\text { (e.g., interviews, observations, } \\
\text { and so on)? } \\
\text { Were specific instruments } \\
\text { adequately described and were } \\
\text { they good choices, given the }\end{array}$ & $\begin{array}{l}\text { The authors performed the study } \\
\text { how they conceptualized it. } \\
\text { Key variables were measured by } \\
\text { direct chart review, post-mortem } \\
\text { examination reports as well as } \\
\text { morbidity and mortality meetings. } \\
\text { This was appropriate for this study. } \\
\text { The method in which the findings } \\
\text { were analyzed was well described. }\end{array}$ \\
\hline
\end{tabular}




\begin{tabular}{|c|c|c|}
\hline & $\begin{array}{l}\text { study population and the } \\
\text { variables being studied? } \\
\text { Did the report provide } \\
\text { evidence that the data } \\
\text { collection methods yielded } \\
\text { data that were reliable, valid } \\
\text { and responsive? }\end{array}$ & $\begin{array}{l}\text { The report did not provide evidence } \\
\text { that data collection were valid or } \\
\text { reliable. }\end{array}$ \\
\hline Procedures & $\begin{array}{l}\text { If there was an intervention, } \\
\text { was it adequately described, } \\
\text { and was it rigorously } \\
\text { developed and implemented? } \\
\text { Did most participants allocated } \\
\text { to the intervention group } \\
\text { actually receive it? Was there } \\
\text { evidence of intervention } \\
\text { fidelity? } \\
\text { Were data collected in a } \\
\text { manner that minimized bias? } \\
\text { Were the staff who collected } \\
\text { data appropriately trained? }\end{array}$ & $\begin{array}{l}\text { It was not addressed in the study if } \\
\text { one or both of the authors reviewed } \\
\text { the data. The qualifications of the } \\
\text { authors was not discussed. } \\
\text { There was not an intervention in this } \\
\text { study. }\end{array}$ \\
\hline Data Analysis & $\begin{array}{l}\text { - Were analyses undertaken to } \\
\text { address each research question } \\
\text { or test each hypothesis? } \\
\text { Were appropriate statistical } \\
\text { methods used, given the level } \\
\text { of measurement of the } \\
\text { variables, number of groups } \\
\text { being compared, and } \\
\text { assumptions of the texts? } \\
\text { Was a powerful analytic } \\
\text { method used? (e.g., did the } \\
\text { analysis help to control for } \\
\text { confounding variables)? } \\
\text { Were type I and Type II errors } \\
\text { avoided or minimized? } \\
\text { In intervention studies, was an } \\
\text { intention-to-treat analysis } \\
\text { performed? } \\
\text { Were problems of missing } \\
\text { values evaluated and } \\
\text { adequately addressed? }\end{array}$ & $\begin{array}{l}\text { The data were well analyzed to } \\
\text { address the research question. } \\
\text { The statistical method was } \\
\text { appropriate given the small number } \\
\text { of cases studied and the goals of the } \\
\text { authors. } \\
\text { A powerful analytic method was not } \\
\text { used nor indicated given the type of } \\
\text { study, and errors were not } \\
\text { minimized. }\end{array}$ \\
\hline Findings & $\begin{array}{l}\text { - Was information about } \\
\text { statistical significance } \\
\text { presented? Was information } \\
\text { about effect size and precision } \\
\text { of estimates (confidence } \\
\text { intervals) presented? } \\
\text { Were the findings adequately } \\
\text { summarized, with good use of } \\
\text { tables and figures? } \\
\text { Were findings reported in a } \\
\text { manner that facilitates a meta- }\end{array}$ & $\begin{array}{l}\text { No statistical significance was } \\
\text { included. } \\
\text { The findings were well summarized } \\
\text { including tables and figures. } \\
\text { The findings suggested a deficiency } \\
\text { in care but did not elicit specific } \\
\text { change. Further studies with a larger } \\
\text { study size would be needed for } \\
\text { EBP. }\end{array}$ \\
\hline
\end{tabular}




\begin{tabular}{|c|c|c|}
\hline & $\begin{array}{l}\text { analysis, and with sufficient } \\
\text { information needed for EBP? }\end{array}$ & \\
\hline $\begin{array}{l}\text { Discussion } \\
\text { Interpretation of the } \\
\text { findings }\end{array}$ & $\begin{array}{l}\text { Were all major findings } \\
\text { interpreted and discussed } \\
\text { within the context of prior } \\
\text { research and/or the study's } \\
\text { conceptual framework? } \\
\text { - Were casual inferences, if any, } \\
\text { justified? } \\
\text { - Was the issue of clinical } \\
\text { significance discussed? } \\
\text { Were interpretations well- } \\
\text { founded and consistent with } \\
\text { the study’s limitations? } \\
\text { Did the report address the issue } \\
\text { of the generalizability of the } \\
\text { findings? }\end{array}$ & $\begin{array}{l}\text { The findings were discussed in the } \\
\text { context of the research question.. } \\
\text { Casual inferences were made and } \\
\text { justified given the results of the } \\
\text { study. } \\
\text { Clinical significance was discussed } \\
\text { and interpretations were generally } \\
\text { appropriate given the limitation of } \\
\text { the study. } \\
\text { The study did not attempt to } \\
\text { generalize to other LMICs and } \\
\text { listed this in the limitations section } \\
\text { of the this study. }\end{array}$ \\
\hline $\begin{array}{l}\text { Implications/ } \\
\text { recommendations }\end{array}$ & $\begin{array}{l}\text { Did the researchers discuss the } \\
\text { implications of the study for } \\
\text { clinical practice or further } \\
\text { research—and were those } \\
\text { implications reasonable and } \\
\text { complete? }\end{array}$ & $\begin{array}{l}\text { The authors reasonably identified } \\
\text { the need for further study into } \\
\text { anesthetic deaths in tertiary } \\
\text { hospitals. }\end{array}$ \\
\hline $\begin{array}{l}\text { General Issues } \\
\text { Presentation }\end{array}$ & $\begin{array}{l}\text { Was the report well-written, } \\
\text { organized, and sufficiently } \\
\text { detailed for critical analysis? } \\
\text { Was the report written in a } \\
\text { manner that makes the findings } \\
\text { accessible to practicing nurses? }\end{array}$ & $\begin{array}{l}\text { The report was easy to follow but } \\
\text { only two tables were included and } \\
\text { provided limited data for review. } \\
\text { Case summaries were included for } \\
\text { each patient . }\end{array}$ \\
\hline Researcher credibility & $\begin{array}{l}\text { Do the researchers' clinical, } \\
\text { substantive, or methodologic } \\
\text { qualifications and experience } \\
\text { enhance confidence in the } \\
\text { findings and their } \\
\text { interpretation? }\end{array}$ & $\begin{array}{l}\text { The researchers' qualifications were } \\
\text { not identified in this study. }\end{array}$ \\
\hline Summary assessment & $\begin{array}{l}\text { Despite any limitations, do the } \\
\text { study findings appear to be } \\
\text { valid-do you have confidence } \\
\text { in the truth value of the } \\
\text { results? } \\
\text { - Does the study contribute any } \\
\text { meaningful evidence that can } \\
\text { be used in nursing practice or } \\
\text { that is useful to the nursing } \\
\text { discipline? }\end{array}$ & $\begin{array}{l}\text { Meaningful changes could be made } \\
\text { based off of the recommendations } \\
\text { of this study. }\end{array}$ \\
\hline
\end{tabular}




\section{Appendix A-4}

Khan, K. S., Wojdyla, D., Say, L., Gülmezoglu, A. M., \& Van Look, P. F. A. (2006). WHO analysis of causes of maternal death: a systematic review. The Lancet, 367(9516), 10661074. doi: 10.1016/s0140-6736(06)68397-9

\begin{tabular}{|c|c|c|}
\hline \multicolumn{2}{|r|}{ Critiquing Questions } & $\begin{array}{c}\text { Critique Responses } \\
\end{array}$ \\
\hline & $\begin{array}{l}\text { Is the review thorough- does it } \\
\text { include all major studies on the } \\
\text { topic? Does it include recent } \\
\text { research (studies published } \\
\text { within previous 2-3 years)? Are } \\
\text { studies from other related } \\
\text { disciplines included, if } \\
\text { appropriate? }\end{array}$ & $\begin{array}{l}\text { The review was thorough and included all the available } \\
\text { literature up to the time the study was completed. A search } \\
\text { was completed using relevant search terms. An a-priori } \\
\text { protocol was developed with a widely recommended } \\
\text { methodology. A time limit was set to review recent data. }\end{array}$ \\
\hline & $\begin{array}{l}\text { Does the review rely mainly on } \\
\text { primary source research articles? } \\
\text { Are the articles from peer- } \\
\text { reviewed journals? }\end{array}$ & $\begin{array}{l}\text { The review relied on journal articles, registries, and } \\
\text { published or unpublished information from government or } \\
\text { other agencies. It was not established if the articles were } \\
\text { from peer-reviewed journals. }\end{array}$ \\
\hline 3. & $\begin{array}{l}\text { Is the review merely a summary } \\
\text { of existing work, or does it } \\
\text { critically appraise and compare } \\
\text { key studies? Does the review } \\
\text { identify important gaps in the } \\
\text { literature? }\end{array}$ & $\begin{array}{l}\text { The review critically appraised and compared two different } \\
\text { data sets and critically appraises existing studies. }\end{array}$ \\
\hline & $\begin{array}{l}\text { Is the review well organized? Is } \\
\text { the development of ideas clear? }\end{array}$ & $\begin{array}{l}\text { The review was well organized and the ideas are developed } \\
\text { clearly with the support of the literature. Tables, maps and } \\
\text { graphs were used to enhance the article. }\end{array}$ \\
\hline & $\begin{array}{l}\text { Does the review use appropriate } \\
\text { language, suggesting the } \\
\text { tentativeness of prior findings? } \\
\text { Is the review objective? Does } \\
\text { the author paraphrase, or is there } \\
\text { an overreliance on quotes from } \\
\text { original sources? }\end{array}$ & $\begin{array}{l}\text { The review used appropriate language and is objective, } \\
\text { using independent assessments of two reviewers. } \\
\text { Confidence intervals were established. It is objective and } \\
\text { uses a variety statistical appraisal tools to support the } \\
\text { author’s findings. }\end{array}$ \\
\hline & $\begin{array}{l}\text { If the review is part of a research } \\
\text { report for a new study, does the } \\
\text { review support the need for the } \\
\text { study? }\end{array}$ & Not applicable \\
\hline & $\begin{array}{l}\text { If it is a review designed to } \\
\text { summarize evidence for clinical } \\
\text { practice, does the review draw } \\
\text { reasonable conclusions about } \\
\text { practice implications? }\end{array}$ & $\begin{array}{l}\text { The review identified the primary causes of maternal } \\
\text { mortality in LMICs and suggested the need for further } \\
\text { studies and emphasis on programs relevant to specific } \\
\text { settings. }\end{array}$ \\
\hline & $\begin{array}{l}\text { Was the issue of clinical } \\
\text { significance discussed? Were } \\
\text { interpretations well-founded and } \\
\text { consistent with the study's } \\
\text { limitations? Did the report } \\
\text { address the issue of the } \\
\text { generalizability of the findings? }\end{array}$ & $\begin{array}{l}\text { Clinical significance was discussed and interpretations were } \\
\text { appropriate. } \\
\text { Because of breadth of this study, findings were generizable } \\
\text { to other LMICs. }\end{array}$ \\
\hline
\end{tabular}




\section{Appendix A-5}

Hodges, S. C., Mijumbi, C., Okello, M., McCormick, B. A., Walker, I. A., \& Wilson, I. H. (2007). Anaesthesia services in developing countries: defining the problems. Anaesthesia, 62(1), 4-11. doi: 10.1111/j.1365-2044.2006.04907.x

\begin{tabular}{|c|c|c|}
\hline Aspect of the Report & Critiquing Questions & Detailed Critiquing Guidelines \\
\hline Title & $\begin{array}{l}\text { Is the title a good one, } \\
\text { suggesting the key } \\
\text { phenomenon and the group or } \\
\text { community under study? }\end{array}$ & $\begin{array}{l}\text { The title clearly identified the } \\
\text { subject, location, and demographics } \\
\text { of the study. }\end{array}$ \\
\hline Abstract & $\begin{array}{l}\text { Does the abstract clearly and } \\
\text { concisely summarize the main } \\
\text { features of the report? }\end{array}$ & $\begin{array}{l}\text { The abstract outlined all the } \\
\text { components of the study. }\end{array}$ \\
\hline $\begin{array}{l}\text { Introduction } \\
\text { Statement of the } \\
\text { problem }\end{array}$ & $\begin{array}{l}\text { - Was the problem stated } \\
\text { unambiguously and is it easy } \\
\text { to identify? } \\
\text { - Did the problem statement } \\
\text { build a cogent and persuasive } \\
\text { argument for the new study? } \\
\text { - Was the problem significant } \\
\text { for nursing? } \\
\text { Was there a good match } \\
\text { between the research problem } \\
\text { on the one hand and the } \\
\text { paradigm, tradition, and } \\
\text { methods on the other - that is, } \\
\text { was a qualitative approach } \\
\text { appropriate? }\end{array}$ & $\begin{array}{l}\text { The problem was identified clearly } \\
\text { and thoroughly and suggests a need } \\
\text { for further study. } \\
\text { The problem is significant for } \\
\text { nursing anesthesia practice as } \\
\text { results can identify deficiencies and } \\
\text { potential areas for change. } \\
\text { A cross-sectional survey was } \\
\text { performed which worked well with } \\
\text { the goals of this study. }\end{array}$ \\
\hline Research questions & $\begin{array}{l}\text { Were research questions } \\
\text { explicitly stated? If not, was } \\
\text { their absence justified? } \\
\text { Were the questions consistent } \\
\text { with the study's philosophical } \\
\text { basis, underlying tradition, or } \\
\text { ideologic orientation? }\end{array}$ & $\begin{array}{l}\text { The research questions and goals } \\
\text { were explicitly stated at the end of } \\
\text { the introduction. } \\
\text { The question was consistent with } \\
\text { the study's philosophical basis. }\end{array}$ \\
\hline Literature review & $\begin{array}{l}\text { Did the report adequately } \\
\text { summarize the existing body } \\
\text { of knowledge related to the } \\
\text { problem or phenomenon of } \\
\text { interest? } \\
\text { - Did the literature review } \\
\text { provide a strong basis for the } \\
\text { new study? }\end{array}$ & $\begin{array}{l}\text { There was not a formal literature } \\
\text { review included in this study. }\end{array}$ \\
\hline $\begin{array}{l}\text { Conceptual } \\
\text { underpinnings }\end{array}$ & $\begin{array}{l}\text { Were key concepts adequately } \\
\text { defined conceptually? } \\
\text { Was the philosophical basis, } \\
\text { underlying tradition, } \\
\text { conceptual framework, or } \\
\text { ideologic orientation made } \\
\text { explicit and was it appropriate } \\
\text { for the problem? }\end{array}$ & $\begin{array}{l}\text { Key concepts were well defined in } \\
\text { the body of the paper, including the } \\
\text { basis for the survey. }\end{array}$ \\
\hline $\begin{array}{l}\text { Conceptual/theoretical } \\
\text { framework }\end{array}$ & $\begin{array}{l}\text { Were key concepts adequately } \\
\text { defined conceptually? }\end{array}$ & $\begin{array}{l}\text { There was not a theoretical } \\
\text { framework referenced in this study. }\end{array}$ \\
\hline
\end{tabular}




\begin{tabular}{|c|c|c|}
\hline & $\begin{array}{l}\text { - Was a conceptual/theoretical } \\
\text { framework articulated-and, if } \\
\text { so, was it appropriate? If not, } \\
\text { is the absence of a framework } \\
\text { justified? } \\
\text { - Were the questions/hypotheses } \\
\text { consistent with the framework? }\end{array}$ & \\
\hline $\begin{array}{l}\text { Method } \\
\text { Protection of human } \\
\text { rights }\end{array}$ & $\begin{array}{l}\text { Were appropriate procedures } \\
\text { used to safe-guard the rights of } \\
\text { study participants? } \\
\text { - Was the study externally } \\
\text { reviewed by an IRB/ethics } \\
\text { review board? } \\
\text { - Was the study designed to } \\
\text { minimize risks and maximize } \\
\text { benefits to participants? }\end{array}$ & $\begin{array}{l}\text { This was not addressed, but names } \\
\text { and other identifying markers were } \\
\text { not included in the study. }\end{array}$ \\
\hline Research design & $\begin{array}{l}\text { - Was the most rigorous design } \\
\text { used, given the study purpose? } \\
\text { Were appropriate comparisons } \\
\text { made to enhance } \\
\text { interpretability of the findings? } \\
\text { - Was the number of data } \\
\text { collection points appropriate? } \\
\text { Did the design minimize biases } \\
\text { and threats to the internal, } \\
\text { construct, and external validity } \\
\text { of the study (e.g., was blinding } \\
\text { used, was attrition } \\
\text { minimized)? }\end{array}$ & $\begin{array}{l}\text { A cross-sectional survey was } \\
\text { appropriate for the author's goals. } \\
\text { The questionnaire was based off of } \\
\text { established international guidelines. } \\
\text { It was prepared, piloted and then } \\
\text { revised. } \\
\text { A copy of the questionnaire was not } \\
\text { provided for review. }\end{array}$ \\
\hline $\begin{array}{l}\text { Population and } \\
\text { sample }\end{array}$ & $\begin{array}{l}\text { - Was the population identified? } \\
\text { Was the sample described in } \\
\text { sufficient detail? } \\
\text { - Was the best possible sampling } \\
\text { design used to enhance the } \\
\text { sample's representativeness? } \\
\text { Were sampling biases } \\
\text { minimized? } \\
\text { - Was the sample size based on } \\
\text { a power analysis? }\end{array}$ & $\begin{array}{l}\text { The population was adequately } \\
\text { identified and described in great } \\
\text { detail. } \\
\text { The sample size consisted of all } \\
\text { providers at a conference and was } \\
\text { not based off of a confidence } \\
\text { interval or power analysis. } \\
\text { Questionnaires were distributed to } \\
97 \text { anesthesia providers at a single } \\
\text { conference in Uganda, representing } \\
1 / 3 \text { of the total practicing providers } \\
\text { in the country providing for a good } \\
\text { sample representation. }\end{array}$ \\
\hline $\begin{array}{l}\text { Data collection and } \\
\text { measurement }\end{array}$ & $\begin{array}{l}\text { - Were the operational and } \\
\text { conceptual definitions } \\
\text { congruent? } \\
\text { Were key variables measured } \\
\text { using an appropriate method } \\
\text { (e.g., interviews, observations, } \\
\text { and so on)? } \\
\text { Were specific instruments } \\
\text { adequately described and were } \\
\text { they good choices, given the } \\
\text { study population and the } \\
\text { variables being studied? }\end{array}$ & $\begin{array}{l}\text { The authors performed the study } \\
\text { how they conceptualized it. } \\
\text { Qualitative and quantitative data } \\
\text { were collected using a structured } \\
\text { questionnaire. } \\
\text { The findings were compiled into } \\
\text { tables for review. }\end{array}$ \\
\hline
\end{tabular}




\begin{tabular}{|c|c|c|}
\hline & $\begin{array}{l}\text { Did the report provide } \\
\text { evidence that the data } \\
\text { collection methods yielded } \\
\text { data that were reliable, valid } \\
\text { and responsive? }\end{array}$ & \\
\hline Procedures & $\begin{array}{l}\text { If there was an intervention, } \\
\text { was it adequately described, } \\
\text { and was it rigorously } \\
\text { developed and implemented? } \\
\text { Did most participants allocated } \\
\text { to the intervention group } \\
\text { actually receive it? Was there } \\
\text { evidence of intervention } \\
\text { fidelity? } \\
\text { Were data collected in a } \\
\text { manner that minimized bias? } \\
\text { Were the staff who collected } \\
\text { data appropriately trained? }\end{array}$ & $\begin{array}{l}\text { There were no interventions in this } \\
\text { study. } \\
\text { The data were collected at a } \\
\text { conference so could have only } \\
\text { included those who could afford to } \\
\text { travel and take time off, possibly } \\
\text { contributing to bias. }\end{array}$ \\
\hline Data Analysis & $\begin{array}{l}\text { - } \quad \text { Were analyses undertaken to } \\
\text { address each research question } \\
\text { or test each hypothesis? } \\
\text { - Were appropriate statistical } \\
\text { methods used, given the level } \\
\text { of measurement of the } \\
\text { variables, number of groups } \\
\text { being compared, and } \\
\text { assumptions of the texts? } \\
\text { - Was a powerful analytic } \\
\text { method used? (e.g., did the } \\
\text { analysis help to control for } \\
\text { confounding variables)? } \\
\text { Were type I and Type II errors } \\
\text { avoided or minimized? } \\
\text { In intervention studies, was an } \\
\text { intention-to-treat analysis } \\
\text { performed? } \\
\text { Were problems of missing } \\
\text { values evaluated and } \\
\text { adequately addressed? }\end{array}$ & $\begin{array}{l}\text { The data were appropriately } \\
\text { analyzed to address the research } \\
\text { question. } \\
\text { The statistical method was } \\
\text { appropriate given the goals of the } \\
\text { authors. } \\
\text { The authors compiled the data into } \\
\text { tables but did not address which } \\
\text { analytic method was used. }\end{array}$ \\
\hline Findings & $\begin{array}{l}\text { Was information about } \\
\text { statistical significance } \\
\text { presented? Was information } \\
\text { about effect size and precision } \\
\text { of estimates (confidence } \\
\text { intervals) presented? } \\
\text { - Were the findings adequately } \\
\text { summarized, with good use of } \\
\text { tables and figures? } \\
\text { Were findings reported in a } \\
\text { manner that facilitates a meta- } \\
\text { analysis, and with sufficient } \\
\text { information needed for EBP? }\end{array}$ & $\begin{array}{l}\text { Statistical significance and } \\
\text { confidence intervals not presented } \\
\text { in this study. } \\
\text { The findings were well summarized } \\
\text { including tables and figures. } \\
\text { The findings could be used in future } \\
\text { studies, including meta- analysis as } \\
\text { well as be used for EBP. }\end{array}$ \\
\hline $\begin{array}{l}\text { Discussion } \\
\text { Interpretation of the } \\
\text { findings }\end{array}$ & $\begin{array}{l}\text { Were all major findings } \\
\text { interpreted and discussed } \\
\text { within the context of prior }\end{array}$ & $\begin{array}{l}\text { The findings were discussed in the } \\
\text { context of the research question. }\end{array}$ \\
\hline
\end{tabular}




\begin{tabular}{|c|c|c|}
\hline & $\begin{array}{l}\text { research and/or the study’s } \\
\text { conceptual framework? } \\
\text { Were casual inferences, if any, } \\
\text { justified? } \\
\text { Was the issue of clinical } \\
\text { significance discussed? } \\
\text { Were interpretations well- } \\
\text { founded and consistent with } \\
\text { the study’s limitations? } \\
\text { Did the report address the issue } \\
\text { of the generalizability of the } \\
\text { findings? }\end{array}$ & $\begin{array}{l}\text { Casual inferences were made and } \\
\text { justified given the results of the } \\
\text { study. } \\
\text { Clinical significance was discussed } \\
\text { and interpretations were } \\
\text { appropriate. The results covered a } \\
\text { broad range of topics relating to } \\
\text { anesthesia in LMICs. } \\
\text { The results were discussed within } \\
\text { the limits of the study and } \\
\text { addressed by the author. } \\
\text { The study did attempt to generalize } \\
\text { its findings to other LMICs. }\end{array}$ \\
\hline $\begin{array}{l}\text { Implications/ } \\
\text { recommendations }\end{array}$ & $\begin{array}{l}\text { Did the researchers discuss the } \\
\text { implications of the study for } \\
\text { clinical practice or further } \\
\text { research-and were those } \\
\text { implications reasonable and } \\
\text { complete? }\end{array}$ & $\begin{array}{l}\text { The authors reasonably identified } \\
\text { deficiencies in obstetric anesthesia } \\
\text { care and provided appropriate } \\
\text { recommendations. }\end{array}$ \\
\hline $\begin{array}{l}\text { General Issues } \\
\text { Presentation }\end{array}$ & $\begin{array}{l}\text { Was the report well-written, } \\
\text { organized, and sufficiently } \\
\text { detailed for critical analysis? } \\
\text { Was the report written in a } \\
\text { manner that makes the findings } \\
\text { accessible to practicing nurses? }\end{array}$ & $\begin{array}{l}\text { The report was easy to follow and } \\
\text { the data was clearly outlined and } \\
\text { made available for critical analysis. }\end{array}$ \\
\hline Researcher credibility & $\begin{array}{l}\text { Do the researchers' clinical, } \\
\text { substantive, or methodologic } \\
\text { qualifications and experience } \\
\text { enhance confidence in the } \\
\text { findings and their } \\
\text { interpretation? }\end{array}$ & $\begin{array}{l}\text { The researchers' qualifications } \\
\text { enhance confidence in the findings } \\
\text { of the study. }\end{array}$ \\
\hline Summary assessment & $\begin{array}{l}\text { - Despite any limitations, do the } \\
\text { study findings appear to be } \\
\text { valid-do you have confidence } \\
\text { in the truth value of the } \\
\text { results? } \\
\text { Does the study contribute any } \\
\text { meaningful evidence that can } \\
\text { be used in nursing practice or } \\
\text { that is useful to the nursing } \\
\text { discipline? }\end{array}$ & $\begin{array}{l}\text { The study findings appear to be } \\
\text { reasonable and translatable to other } \\
\text { LMICs with similar healthcare } \\
\text { demographics. } \\
\text { Meaningful changes can be made } \\
\text { based off of the recommendations } \\
\text { of this study. }\end{array}$ \\
\hline
\end{tabular}




\section{Appendix A-6}

Ajuzieogu, O. V., Ezike, H. A., Amucheazi, A. O., \& Enwereji, J. (2011). A retrospective study of the outcome of cesarean section for women with severe pre-eclampsia in a third world setting. Saudi J Anaesth, 5(1), 15-18. doi: 10.4103/1658-354x.76480

\begin{tabular}{|c|c|c|}
\hline Aspect of the Report & Critiquing Questions & Detailed Critiquing Guidelines \\
\hline Title & $\begin{array}{l}\text { Is the title a good one, } \\
\text { suggesting the key } \\
\text { phenomenon and the group or } \\
\text { community under study? }\end{array}$ & $\begin{array}{l}\text { The title clearly identified the } \\
\text { subject of the study and } \\
\text { demographics but does not specify } \\
\text { which country or the timeframe. }\end{array}$ \\
\hline Abstract & $\begin{array}{l}\text { Does the abstract clearly and } \\
\text { concisely summarize the main } \\
\text { features of the report? }\end{array}$ & $\begin{array}{l}\text { The abstract outlined all the } \\
\text { components of the study. }\end{array}$ \\
\hline $\begin{array}{l}\text { Introduction } \\
\text { Statement of the } \\
\text { problem }\end{array}$ & $\begin{array}{l}\text { Was the problem stated } \\
\text { unambiguously and is it easy } \\
\text { to identify? } \\
\text { Did the problem statement } \\
\text { build a cogent and persuasive } \\
\text { argument for the new study? } \\
\text { - Was the problem significant } \\
\text { for nursing? } \\
\text { - Was there a good match } \\
\text { between the research problem } \\
\text { on the one hand and the } \\
\text { paradigm, tradition, and } \\
\text { methods on the other - that is, } \\
\text { was a qualitative approach } \\
\text { appropriate? }\end{array}$ & $\begin{array}{l}\text { The problem was identified clearly } \\
\text { and defined the difficulty of treating } \\
\text { and managing patients with pre- } \\
\text { eclampsia in LMICs. } \\
\text { The problem is significant for nurse } \\
\text { anesthesia practice as results can } \\
\text { provide guidance for practice in } \\
\text { LMICs. } \\
\text { A retrospective analysis was } \\
\text { appropriate for the goals of the } \\
\text { authors. }\end{array}$ \\
\hline Research questions & $\begin{array}{l}\text { Were research questions } \\
\text { explicitly stated? If not, was } \\
\text { their absence justified? } \\
\text { - Were the questions consistent } \\
\text { with the study's philosophical } \\
\text { basis, underlying tradition, or } \\
\text { ideologic orientation? }\end{array}$ & $\begin{array}{l}\text { The research question was stated } \\
\text { explicitly in the introduction. } \\
\text { The question was consistent with } \\
\text { the study's philosophical basis. }\end{array}$ \\
\hline Literature review & $\begin{array}{l}\text { Did the report adequately } \\
\text { summarize the existing body } \\
\text { of knowledge related to the } \\
\text { problem or phenomenon of } \\
\text { interest? } \\
\text { - Did the literature review } \\
\text { provide a strong basis for the } \\
\text { new study? }\end{array}$ & $\begin{array}{l}\text { A literature search was completed } \\
\text { by the authors showing a sparsity of } \\
\text { studies. }\end{array}$ \\
\hline $\begin{array}{l}\text { Conceptual } \\
\text { underpinnings }\end{array}$ & $\begin{array}{l}\text { Were key concepts adequately } \\
\text { defined conceptually? } \\
\text { Was the philosophical basis, } \\
\text { underlying tradition, } \\
\text { conceptual framework, or } \\
\text { ideologic orientation made } \\
\text { explicit and was it appropriate } \\
\text { for the problem? }\end{array}$ & $\begin{array}{l}\text { Key concepts were defined, such as } \\
\text { the pre-eclampsia and types of } \\
\text { anesthesia. }\end{array}$ \\
\hline
\end{tabular}




\begin{tabular}{|c|c|c|}
\hline $\begin{array}{l}\text { Conceptual/theoretical } \\
\text { framework }\end{array}$ & $\begin{array}{l}\text { - Were key concepts adequately } \\
\text { defined conceptually? } \\
\text { - Was a conceptual/theoretical } \\
\text { framework articulated-and, if } \\
\text { so, was it appropriate? If not, } \\
\text { is the absence of a framework } \\
\text { justified? } \\
\text { - Were the questions/hypotheses } \\
\text { consistent with the framework? }\end{array}$ & $\begin{array}{l}\text { There was no theoretical framework } \\
\text { identified which seemed appropriate } \\
\text { for this type of study. }\end{array}$ \\
\hline $\begin{array}{l}\text { Method } \\
\text { Protection of human } \\
\text { rights }\end{array}$ & $\begin{array}{l}\text { - Were appropriate procedures } \\
\text { used to safe-guard the rights of } \\
\text { study participants? } \\
\text { - Was the study externally } \\
\text { reviewed by an IRB/ethics } \\
\text { review board? } \\
\text { - Was the study designed to } \\
\text { minimize risks and maximize } \\
\text { benefits to participants? }\end{array}$ & $\begin{array}{l}\text { This was not addressed, but names } \\
\text { and other identifying markers were } \\
\text { not included in the study. }\end{array}$ \\
\hline Research design & $\begin{array}{l}\text { Was the most rigorous design } \\
\text { used, given the study purpose? } \\
\text { Were appropriate comparisons } \\
\text { made to enhance } \\
\text { interpretability of the findings? } \\
\text { - Was the number of data } \\
\text { collection points appropriate? } \\
\text { Did the design minimize biases } \\
\text { and threats to the internal, } \\
\text { construct, and external validity } \\
\text { of the study (e.g., was blinding } \\
\text { used, was attrition } \\
\text { minimized)? }\end{array}$ & $\begin{array}{l}\text { A retrospective analysis was } \\
\text { appropriate to compare the } \\
\text { outcomes of general anesthesia vs. } \\
\text { sub-arachnoid block for cesarean } \\
\text { section in pre-eclampsia. } \\
\text { The number of data points were } \\
\text { appropriate as it included all } \\
\text { surgical missions within the set } \\
\text { timeframe of } 5 \text { years. }\end{array}$ \\
\hline $\begin{array}{l}\text { Population and } \\
\text { sample }\end{array}$ & $\begin{array}{l}\text { Was the population identified? } \\
\text { Was the sample described in } \\
\text { sufficient detail? } \\
\text { Was the best possible sampling } \\
\text { design used to enhance the } \\
\text { sample's representativeness? } \\
\text { Were sampling biases } \\
\text { minimized? } \\
\text { Was the sample size based on } \\
\text { a power analysis? }\end{array}$ & $\begin{array}{l}\text { The population was adequately } \\
\text { identified and described in detail. } \\
\text { The sample size was not based on a } \\
\text { power analysis. } \\
\text { The percentage of cesarean-sections } \\
\text { performed due to pre-eclampsia in } \\
\text { the study setting was similar to the } \\
\text { worldwide incidence. }\end{array}$ \\
\hline $\begin{array}{l}\text { Data collection and } \\
\text { measurement }\end{array}$ & $\begin{array}{l}\text { - Were the operational and } \\
\text { conceptual definitions } \\
\text { congruent? } \\
\text { Were key variables measured } \\
\text { using an appropriate method } \\
\text { (e.g., interviews, observations, } \\
\text { and so on)? } \\
\text { Were specific instruments } \\
\text { adequately described and were } \\
\text { they good choices, given the } \\
\text { study population and the } \\
\text { variables being studied? } \\
\text { Did the report provide } \\
\text { evidence that the data }\end{array}$ & $\begin{array}{l}\text { The authors performed the study } \\
\text { how they conceptualized it. } \\
\text { Data on maternal age, parity, } \\
\text { gestational age at delivery, booking } \\
\text { status, APGAR scores, maternal } \\
\text { mortality and perinatal mortality } \\
\text { were extracted. }\end{array}$ \\
\hline
\end{tabular}




\begin{tabular}{|c|c|c|}
\hline & $\begin{array}{l}\text { collection methods yielded } \\
\text { data that were reliable, valid } \\
\text { and responsive? }\end{array}$ & \\
\hline Procedures & $\begin{array}{l}\text { If there was an intervention, } \\
\text { was it adequately described, } \\
\text { and was it rigorously } \\
\text { developed and implemented? } \\
\text { Did most participants allocated } \\
\text { to the intervention group } \\
\text { actually receive it? Was there } \\
\text { evidence of intervention } \\
\text { fidelity? } \\
\text { Were data collected in a } \\
\text { manner that minimized bias? } \\
\text { Were the staff who collected } \\
\text { data appropriately trained? }\end{array}$ & $\begin{array}{l}\text { There was not an intervention in } \\
\text { this study. } \\
\text { It was not described who reviewed } \\
\text { the data and how biases would have } \\
\text { been minimized. } \\
\text { Exclusion criteria was well defined. }\end{array}$ \\
\hline Data Analysis & $\begin{array}{l}\text { - } \quad \text { Were analyses undertaken to } \\
\text { address each research question } \\
\text { or test each hypothesis? } \\
\text { - Were appropriate statistical } \\
\text { methods used, given the level } \\
\text { of measurement of the } \\
\text { variables, number of groups } \\
\text { being compared, and } \\
\text { assumptions of the texts? } \\
\text { - Was a powerful analytic } \\
\text { method used? (e.g., did the } \\
\text { analysis help to control for } \\
\text { confounding variables)? } \\
\text { Were type I and Type II errors } \\
\text { avoided or minimized? } \\
\text { In intervention studies, was an } \\
\text { intention-to-treat analysis } \\
\text { performed? } \\
\text { Were problems of missing } \\
\text { values evaluated and } \\
\text { adequately addressed? }\end{array}$ & $\begin{array}{l}\text { The data was well analyzed to } \\
\text { address the research questions. } \\
\text { The statistical method was } \\
\text { appropriate using chi-square, } \\
\text { student t-test, and Fischer exact test } \\
\text { as appropriate. } \\
\text { SPSS version } 10.0 \text { statistical } \\
\text { software was used. }\end{array}$ \\
\hline Findings & $\begin{array}{l}\text { Was information about } \\
\text { statistical significance } \\
\text { presented? Was information } \\
\text { about effect size and precision } \\
\text { of estimates (confidence } \\
\text { intervals) presented? } \\
\text { - Were the findings adequately } \\
\text { summarized, with good use of } \\
\text { tables and figures? } \\
\text { Were findings reported in a } \\
\text { manner that facilitates a meta- } \\
\text { analysis, and with sufficient } \\
\text { information needed for EBP? }\end{array}$ & $\begin{array}{l}\text { A P-value of }<0.05 \text { was used for } \\
\text { statistical significance. } \\
\text { The findings were well summarized } \\
\text { including tables and figures. } \\
\text { The findings suggested the need for } \\
\text { further studies and made } \\
\text { suggestions for change. }\end{array}$ \\
\hline $\begin{array}{l}\text { Discussion } \\
\text { Interpretation of the } \\
\text { findings }\end{array}$ & $\begin{array}{l}\text { Were all major findings } \\
\text { interpreted and discussed } \\
\text { within the context of prior } \\
\text { research and/or the study’s } \\
\text { conceptual framework? }\end{array}$ & $\begin{array}{l}\text { The findings were discussed in the } \\
\text { context of the research questions. } \\
\text { Casual inferences were made and } \\
\text { justified given the results of the } \\
\text { study. }\end{array}$ \\
\hline
\end{tabular}




\begin{tabular}{|c|c|c|}
\hline & $\begin{array}{l}\text { Were casual inferences, if any, } \\
\text { justified? } \\
\text { Was the issue of clinical } \\
\text { significance discussed? } \\
\text { Were interpretations well- } \\
\text { founded and consistent with } \\
\text { the study's limitations? } \\
\text { - Did the report address the issue } \\
\text { of the generalizability of the } \\
\text { findings? }\end{array}$ & $\begin{array}{l}\text { Clinical significance was discussed } \\
\text { and interpretations were appropriate } \\
\text { citing the P-values. } \\
\text { The generalizability of this data was } \\
\text { not discussed but can be possibly be } \\
\text { used in LMICs with similar } \\
\text { anesthetic challenges. }\end{array}$ \\
\hline $\begin{array}{l}\text { Implications/ } \\
\text { recommendations }\end{array}$ & $\begin{array}{l}\text { Did the researchers discuss the } \\
\text { implications of the study for } \\
\text { clinical practice or further } \\
\text { research-and were those } \\
\text { implications reasonable and } \\
\text { complete? }\end{array}$ & $\begin{array}{l}\text { The authors briefly discussed the } \\
\text { implications of their study findings, } \\
\text { however greater detail and further } \\
\text { practice recommendations is } \\
\text { needed. }\end{array}$ \\
\hline $\begin{array}{l}\text { General Issues } \\
\text { Presentation }\end{array}$ & $\begin{array}{l}\text { Was the report well-written, } \\
\text { organized, and sufficiently } \\
\text { detailed for critical analysis? } \\
\text { Was the report written in a } \\
\text { manner that makes the findings } \\
\text { accessible to practicing nurses? }\end{array}$ & $\begin{array}{l}\text { The report was easy to follow and } \\
\text { was well organized. Subheadings } \\
\text { were an effective way to outline the } \\
\text { data. }\end{array}$ \\
\hline Researcher credibility & $\begin{array}{l}\text { Do the researchers' clinical, } \\
\text { substantive, or methodologic } \\
\text { qualifications and experience } \\
\text { enhance confidence in the } \\
\text { findings and their } \\
\text { interpretation? } \\
\end{array}$ & $\begin{array}{l}\text { There was information about the } \\
\text { author's qualifications and } \\
\text { experience. }\end{array}$ \\
\hline Summary assessment & $\begin{array}{l}\text { Despite any limitations, do the } \\
\text { study findings appear to be } \\
\text { valid—do you have confidence } \\
\text { in the truth value of the } \\
\text { results? } \\
\text { - Does the study contribute any } \\
\text { meaningful evidence that can } \\
\text { be used in nursing practice or } \\
\text { that is useful to the nursing } \\
\text { discipline? }\end{array}$ & $\begin{array}{l}\text { The study findings appear to be } \\
\text { valid and translatable to other } \\
\text { LMICs with similar healthcare } \\
\text { demographics. } \\
\text { Meaningful changes can be made } \\
\text { based off of the recommendations } \\
\text { of this study if further analysis is } \\
\text { provided. }\end{array}$ \\
\hline
\end{tabular}




\section{Appendix A-7}

Anderson, R. E., Ahn, R., Nelson, B. D., Chavez, J., de Redon, E., \& Burke, T. (2014). Defining the anesthesia gap for reproductive health procedures in resource-limited settings. Int $J$ Gynaecol Obstet, 127(3), 229-233. doi: 10.1016/j.ijgo.2014.06.023

\begin{tabular}{|c|c|c|}
\hline \multicolumn{2}{|r|}{ Critiquing Questions } & $\begin{array}{c}\text { Critique Responses } \\
\end{array}$ \\
\hline & $\begin{array}{l}\text { Is the review thorough- does it } \\
\text { include all major studies on the } \\
\text { topic? Does it include recent } \\
\text { research (studies published } \\
\text { within previous 2-3 years)? Are } \\
\text { studies from other related } \\
\text { disciplines included, if } \\
\text { appropriate? }\end{array}$ & $\begin{array}{l}\text { The review was thorough and included all the available } \\
\text { literature up to the time the study was completed. A search } \\
\text { was completed using relevant search terms. All literature } \\
\text { was included without a specified time frame which could } \\
\text { result in outdated findings, although none of the literature } \\
\text { selected for final review was before } 1998 \text {. }\end{array}$ \\
\hline 2. & $\begin{array}{l}\text { Does the review rely mainly on } \\
\text { primary source research articles? } \\
\text { Are the articles from peer- } \\
\text { reviewed journals? }\end{array}$ & $\begin{array}{l}\text { The review relied on primary source research articles, } \\
\text { however it was not established if these articles were from } \\
\text { peer-reviewed journals. Editorials, opinion-based, and non- } \\
\text { empirical articles were excluded. }\end{array}$ \\
\hline & $\begin{array}{l}\text { Is the review merely a summary } \\
\text { of existing work, or does it } \\
\text { critically appraise and compare } \\
\text { key studies? Does the review } \\
\text { identify important gaps in the } \\
\text { literature? }\end{array}$ & $\begin{array}{l}\text { The review critically appraised and compared studies } \\
\text { within each result subheading. Gaps in the literature are } \\
\text { discussed. }\end{array}$ \\
\hline & $\begin{array}{l}\text { Is the review well organized? Is } \\
\text { the development of ideas clear? }\end{array}$ & $\begin{array}{l}\text { The review was very well organized and the ideas were } \\
\text { developed clearly with the support of the literature. Each } \\
\text { result had its own subheading which was an effective } \\
\text { layout. }\end{array}$ \\
\hline & $\begin{array}{l}\text { Does the review use appropriate } \\
\text { language, suggesting the } \\
\text { tentativeness of prior findings? } \\
\text { Is the review objective? Does } \\
\text { the author paraphrase, or is there } \\
\text { an overreliance on quotes from } \\
\text { original sources? }\end{array}$ & $\begin{array}{l}\text { The review used appropriate language and identified gaps } \\
\text { and deficiencies in previous findings. There did not appear } \\
\text { to be a statistical approach to the review, and instead the } \\
\text { authors summarized and paraphrased findings within } \\
\text { articles as they related to the subheading of the results } \\
\text { section. }\end{array}$ \\
\hline & $\begin{array}{l}\text { If the review is part of a research } \\
\text { report for a new study, does the } \\
\text { review support the need for the } \\
\text { study? }\end{array}$ & Not applicable \\
\hline & $\begin{array}{l}\text { If it is a review designed to } \\
\text { summarize evidence for clinical } \\
\text { practice, does the review draw } \\
\text { reasonable conclusions about } \\
\text { practice implications? }\end{array}$ & $\begin{array}{l}\text { The review identified deficiencies in clinical practice and } \\
\text { areas for change that was well supported by the analysis. }\end{array}$ \\
\hline & $\begin{array}{l}\text { Was the issue of clinical } \\
\text { significance discussed? Were } \\
\text { interpretations well-founded and } \\
\text { consistent with the study's } \\
\text { limitations? Did the report } \\
\text { address the issue of the } \\
\text { generalizability of the findings? }\end{array}$ & $\begin{array}{l}\text { Clinical significance was discussed and interpretations were } \\
\text { appropriate. The review addressed the risk factors for } \\
\text { maternal and perinatal deaths as related to anesthesia in } \\
\text { LMICs. } \\
\text { Because of breadth of this study, findings were generizable } \\
\text { to other LMICs. }\end{array}$ \\
\hline
\end{tabular}




\section{Appendix A-8}

Hoyler, M., Finlayson, S. R., McClain, C. D., Meara, J. G., \& Hagander, L. (2014). Shortage of doctors, shortage of data: a review of the global surgery, obstetrics, and anesthesia workforce literature. World J Surg, 38(2), 269-280. doi: 10.1007/s00268-013-2324-y

\begin{tabular}{|c|c|c|}
\hline \multicolumn{2}{|r|}{ Critiquing Questions } & Critique Responses \\
\hline & $\begin{array}{l}\text { Is the review thorough- does it } \\
\text { include all major studies on the } \\
\text { topic? Does it include recent } \\
\text { research (studies published } \\
\text { within previous 2-3 years)? Are } \\
\text { studies from other related } \\
\text { disciplines included, if } \\
\text { appropriate? }\end{array}$ & $\begin{array}{l}\text { The review was thorough and included all the available } \\
\text { literature up to the time the study was completed. A search } \\
\text { was completed using relevant search terms. All literature } \\
\text { was included without a specified time frame which could } \\
\text { result in outdated findings, although all but two of the } 37 \\
\text { articles included were from after } 2003 \text {. }\end{array}$ \\
\hline & $\begin{array}{l}\text { Does the review rely mainly on } \\
\text { primary source research articles? } \\
\text { Are the articles from peer- } \\
\text { reviewed journals? }\end{array}$ & $\begin{array}{l}\text { The review relied on primary source research articles, } \\
\text { however it was not established if these articles were from } \\
\text { peer-reviewed journals. Only articles and data relating to } \\
\text { the national or regional number of specialty-trained } \\
\text { physicians were included. }\end{array}$ \\
\hline & $\begin{array}{l}\text { Is the review merely a summary } \\
\text { of existing work, or does it } \\
\text { critically appraise and compare } \\
\text { key studies? Does the review } \\
\text { identify important gaps in the } \\
\text { literature? }\end{array}$ & $\begin{array}{l}\text { The review critically appraised and compared studies and } \\
\text { identified the limitations of the existing surgery workforce } \\
\text { literature. }\end{array}$ \\
\hline & $\begin{array}{l}\text { Is the review well organized? Is } \\
\text { the development of ideas clear? }\end{array}$ & $\begin{array}{l}\text { The review was well organized and the ideas were } \\
\text { developed clearly with the support of the literature. Each } \\
\text { discussion point had its own subheading which was an } \\
\text { effective layout. }\end{array}$ \\
\hline & $\begin{array}{l}\text { Does the review use appropriate } \\
\text { language, suggesting the } \\
\text { tentativeness of prior findings? } \\
\text { Is the review objective? Does } \\
\text { the author paraphrase, or is there } \\
\text { an overreliance on quotes from } \\
\text { original sources? }\end{array}$ & $\begin{array}{l}\text { The review used appropriate language and identified gaps } \\
\text { and deficiencies in previous findings. It was objective and } \\
\text { used a variety statistical appraisal tools to support the } \\
\text { author's findings. }\end{array}$ \\
\hline & $\begin{array}{l}\text { If the review is part of a research } \\
\text { report for a new study, does the } \\
\text { review support the need for the } \\
\text { study? }\end{array}$ & Not applicable \\
\hline & $\begin{array}{l}\text { If it is a review designed to } \\
\text { summarize evidence for clinical } \\
\text { practice, does the review draw } \\
\text { reasonable conclusions about } \\
\text { practice implications? }\end{array}$ & $\begin{array}{l}\text { The review identified deficiencies in the clinical workforce } \\
\text { and areas for change that was well supported by the } \\
\text { analysis. }\end{array}$ \\
\hline & $\begin{array}{l}\text { Was the issue of clinical } \\
\text { significance discussed? Were } \\
\text { interpretations well-founded and } \\
\text { consistent with the study's } \\
\text { limitations? Did the report } \\
\text { address the issue of the } \\
\text { generalizability of the findings? }\end{array}$ & $\begin{array}{l}\text { Clinical significance was discussed and interpretations were } \\
\text { appropriate. The review addressed the shortage of surgical } \\
\text { and anesthesia providers and the need for more } \\
\text { comprehensive data to be collected to help guide } \\
\text { improvements in care. } \\
\text { Because of breadth of this study, findings were generizable } \\
\text { to other LMICs. }\end{array}$ \\
\hline
\end{tabular}




\section{Appendix A-9}

Ologunde, R., Vogel, J. P., Cherian, M. N., Sbaiti, M., Merialdi, M., \& Yeats, J. (2014). Assessment of cesarean delivery availability in 26 low- and middle-income countries: a cross-sectional study. Am J Obstet Gynecol, 211(5), 504.e501-504.e512. doi: 10.1016/j.ajog.2014.05.022

\begin{tabular}{|c|c|c|}
\hline Aspect of the Report & Critiquing Questions & Detailed Critiquing Guidelines \\
\hline Title & $\begin{array}{l}\text { Is the title a good one, } \\
\text { suggesting the key } \\
\text { phenomenon and the group or } \\
\text { community under study? }\end{array}$ & $\begin{array}{l}\text { The title clearly identified the } \\
\text { subject, location, and demographics } \\
\text { of the study. }\end{array}$ \\
\hline Abstract & $\begin{array}{l}\text { Does the abstract clearly and } \\
\text { concisely summarize the main } \\
\text { features of the report? }\end{array}$ & $\begin{array}{l}\text { The abstract outlined all the } \\
\text { components of the study. }\end{array}$ \\
\hline $\begin{array}{l}\text { Introduction } \\
\text { Statement of the } \\
\text { problem }\end{array}$ & $\begin{array}{l}\text { Was the problem stated } \\
\text { unambiguously and is it easy } \\
\text { to identify? } \\
\text { Did the problem statement } \\
\text { build a cogent and persuasive } \\
\text { argument for the new study? } \\
\text { - Was the problem significant } \\
\text { for nursing? } \\
\text { - Was there a good match } \\
\text { between the research problem } \\
\text { on the one hand and the } \\
\text { paradigm, tradition, and } \\
\text { methods on the other - that is, } \\
\text { was a qualitative approach } \\
\text { appropriate? }\end{array}$ & $\begin{array}{l}\text { The problem was identified clearly } \\
\text { and suggests a need for further } \\
\text { study as there is a high level of } \\
\text { maternal mortality in LMICS. } \\
\text { The problem is significant for nurse } \\
\text { anesthesia practice as results can } \\
\text { identify deficiencies and potential } \\
\text { areas for change. } \\
\text { A cross-sectional study was } \\
\text { appropriate for the study goals as a } \\
\text { secondary analysis of a large } \\
\text { number of health facilities can be } \\
\text { included. }\end{array}$ \\
\hline Research questions & $\begin{array}{l}\text { - Were research questions } \\
\text { explicitly stated? If not, was } \\
\text { their absence justified? } \\
\text { Were the questions consistent } \\
\text { with the study’s philosophical } \\
\text { basis, underlying tradition, or } \\
\text { ideologic orientation? }\end{array}$ & $\begin{array}{l}\text { The research question was stated } \\
\text { explicitly in the introduction. } \\
\text { The question was consistent with } \\
\text { the study's philosophical basis. }\end{array}$ \\
\hline Literature review & $\begin{array}{l}\text { Did the report adequately } \\
\text { summarize the existing body } \\
\text { of knowledge related to the } \\
\text { problem or phenomenon of } \\
\text { interest? } \\
\text { - Did the literature review } \\
\text { provide a strong basis for the } \\
\text { new study? }\end{array}$ & $\begin{array}{l}\text { There was no formal literature } \\
\text { review. }\end{array}$ \\
\hline $\begin{array}{l}\text { Conceptual } \\
\text { underpinnings }\end{array}$ & $\begin{array}{l}\text { Were key concepts adequately } \\
\text { defined conceptually? } \\
\text { Was the philosophical basis, } \\
\text { underlying tradition, } \\
\text { conceptual framework, or } \\
\text { ideologic orientation made } \\
\text { explicit and was it appropriate } \\
\text { for the problem? }\end{array}$ & $\begin{array}{l}\text { The Millennium Development goals } \\
\text { were defined within the context of } \\
\text { this study. }\end{array}$ \\
\hline
\end{tabular}




\begin{tabular}{|c|c|c|}
\hline $\begin{array}{l}\text { Conceptual/theoretical } \\
\text { framework }\end{array}$ & $\begin{array}{l}\text { - Were key concepts adequately } \\
\text { defined conceptually? } \\
\text { - Was a conceptual/theoretical } \\
\text { framework articulated-and, if } \\
\text { so, was it appropriate? If not, } \\
\text { is the absence of a framework } \\
\text { justified? } \\
\text { - Were the questions/hypotheses } \\
\text { consistent with the framework? }\end{array}$ & $\begin{array}{l}\text { There was no theoretical framework } \\
\text { identified which seemed appropriate } \\
\text { for this type of study. }\end{array}$ \\
\hline $\begin{array}{l}\text { Method } \\
\text { Protection of human } \\
\text { rights }\end{array}$ & $\begin{array}{l}\text { - Were appropriate procedures } \\
\text { used to safe-guard the rights of } \\
\text { study participants? } \\
\text { - Was the study externally } \\
\text { reviewed by an IRB/ethics } \\
\text { review board? } \\
\text { - Was the study designed to } \\
\text { minimize risks and maximize } \\
\text { benefits to participants? }\end{array}$ & $\begin{array}{l}\text { The survey used to collect the } \\
\text { primary data was anonymous. } \\
\text { Ethical approval was not required } \\
\text { because no patient records or } \\
\text { information was included. }\end{array}$ \\
\hline Research design & $\begin{array}{l}\text { - Was the most rigorous design } \\
\text { used, given the study purpose? } \\
\text { Were appropriate comparisons } \\
\text { made to enhance } \\
\text { interpretability of the findings? } \\
\text { - Was the number of data } \\
\text { collection points appropriate? } \\
\text { Did the design minimize biases } \\
\text { and threats to the internal, } \\
\text { construct, and external validity } \\
\text { of the study (e.g., was blinding } \\
\text { used, was attrition } \\
\text { minimized)? }\end{array}$ & $\begin{array}{l}\text { A cross-sectional study is } \\
\text { appropriate for the author's goals. } \\
\text { The data points were collected by a } \\
\text { previous survey conducted by the } \\
\text { WHO from } 2008 \text { to } 2013 \text {. }\end{array}$ \\
\hline $\begin{array}{l}\text { Population and } \\
\text { sample }\end{array}$ & $\begin{array}{l}\text { Was the population identified? } \\
\text { Was the sample described in } \\
\text { sufficient detail? } \\
\text { Was the best possible sampling } \\
\text { design used to enhance the } \\
\text { sample's representativeness? } \\
\text { Were sampling biases } \\
\text { minimized? } \\
\text { - Was the sample size based on } \\
\text { a power analysis? }\end{array}$ & $\begin{array}{l}\text { The population was adequately } \\
\text { identified and described in detail. } \\
\text { The sample size was not based on a } \\
\text { power analysis. Data extraction was } \\
\text { from previously collected data. } \\
\text { Identification of health facilities for } \\
\text { administration of the analysis tool } \\
\text { was left to the discretion of the } \\
\text { Ministry of Health, WHO country } \\
\text { office and representatives in } \\
\text { individual countries- the data } \\
\text { represents a sample of convenience. }\end{array}$ \\
\hline $\begin{array}{l}\text { Data collection and } \\
\text { measurement }\end{array}$ & $\begin{array}{l}\text { Were the operational and } \\
\text { conceptual definitions } \\
\text { congruent? } \\
\text { Were key variables measured } \\
\text { using an appropriate method } \\
\text { (e.g., interviews, observations, } \\
\text { and so on)? } \\
\text { Were specific instruments } \\
\text { adequately described and were } \\
\text { they good choices, given the }\end{array}$ & $\begin{array}{l}\text { The authors performed the study } \\
\text { how they conceptualized it. } \\
\text { Key variables were measured using } \\
\text { statistical analysis. } \\
\text { The method in which the findings } \\
\text { were analyzed was well described. }\end{array}$ \\
\hline
\end{tabular}




\begin{tabular}{|c|c|c|}
\hline & $\begin{array}{l}\text { study population and the } \\
\text { variables being studied? } \\
\text { Did the report provide } \\
\text { evidence that the data } \\
\text { collection methods yielded } \\
\text { data that were reliable, valid } \\
\text { and responsive? }\end{array}$ & \\
\hline Procedures & $\begin{array}{l}\text { If there was an intervention, } \\
\text { was it adequately described, } \\
\text { and was it rigorously } \\
\text { developed and implemented? } \\
\text { Did most participants allocated } \\
\text { to the intervention group } \\
\text { actually receive it? Was there } \\
\text { evidence of intervention } \\
\text { fidelity? } \\
\text { Were data collected in a } \\
\text { manner that minimized bias? } \\
\text { Were the staff who collected } \\
\text { data appropriately trained? }\end{array}$ & $\begin{array}{l}\text { There was not an intervention in } \\
\text { this study. } \\
\text { To minimize bias as a result of } \\
\text { nonresponse, all reasonable } \\
\text { attempts were made to contact } \\
\text { health facilities with missing data } \\
\text { points. }\end{array}$ \\
\hline Data Analysis & $\begin{array}{l}\text { - Were analyses undertaken to } \\
\text { address each research question } \\
\text { or test each hypothesis? } \\
\text { Were appropriate statistical } \\
\text { methods used, given the level } \\
\text { of measurement of the } \\
\text { variables, number of groups } \\
\text { being compared, and } \\
\text { assumptions of the texts? } \\
\text { Was a powerful analytic } \\
\text { method used? (e.g., did the } \\
\text { analysis help to control for } \\
\text { confounding variables)? } \\
\text { Were type I and Type II errors } \\
\text { avoided or minimized? } \\
\text { In intervention studies, was an } \\
\text { intention-to-treat analysis } \\
\text { performed? } \\
\text { Were problems of missing } \\
\text { values evaluated and } \\
\text { adequately addressed? }\end{array}$ & $\begin{array}{l}\text { The data was well analyzed to } \\
\text { address the research questions. } \\
\text { A powerful analytic method was } \\
\text { used and errors were minimized. } \\
\text { Chi-square tests were performed } \\
\text { and descriptive analysis was used to } \\
\text { compare individual elements of the } \\
\text { survey. }\end{array}$ \\
\hline Findings & $\begin{array}{l}\text { - Was information about } \\
\text { statistical significance } \\
\text { presented? Was information } \\
\text { about effect size and precision } \\
\text { of estimates (confidence } \\
\text { intervals) presented? } \\
\text { - } \quad \text { Were the findings adequately } \\
\text { summarized, with good use of } \\
\text { tables and figures? } \\
\text { Were findings reported in a } \\
\text { manner that facilitates a meta- } \\
\text { analysis, and with sufficient } \\
\text { information needed for EBP? }\end{array}$ & $\begin{array}{l}\text { A P-value of }<0.05 \text { was set as } \\
\text { statically significant. } \\
\text { The findings were well summarized } \\
\text { including tables and figures. } \\
\text { The findings suggested the need for } \\
\text { further studies and made } \\
\text { suggestions for change. }\end{array}$ \\
\hline
\end{tabular}




\begin{tabular}{|c|c|c|}
\hline $\begin{array}{l}\text { Discussion } \\
\text { Interpretation of the } \\
\text { findings }\end{array}$ & $\begin{array}{l}\text { Were all major findings } \\
\text { interpreted and discussed } \\
\text { within the context of prior } \\
\text { research and/or the study's } \\
\text { conceptual framework? } \\
\text { - Were casual inferences, if any, } \\
\text { justified? } \\
\text { - Was the issue of clinical } \\
\text { significance discussed? } \\
\text { Were interpretations well- } \\
\text { founded and consistent with } \\
\text { the study's limitations? } \\
\text { Did the report address the issue } \\
\text { of the generalizability of the } \\
\text { findings? }\end{array}$ & $\begin{array}{l}\text { The findings were discussed in the } \\
\text { context of the research questions. } \\
\text { Casual inferences were made and } \\
\text { justified given the results of the } \\
\text { study. } \\
\text { Clinical significance was discussed } \\
\text { and interpretations were generally } \\
\text { appropriate. } \\
\text { The study did attempt to generalize } \\
\text { its findings to other LMICs. }\end{array}$ \\
\hline $\begin{array}{l}\text { Implications/ } \\
\text { recommendations }\end{array}$ & $\begin{array}{l}\text { Did the researchers discuss the } \\
\text { implications of the study for } \\
\text { clinical practice or further } \\
\text { research-and were those } \\
\text { implications reasonable and } \\
\text { complete? }\end{array}$ & $\begin{array}{l}\text { The authors reasonably identified } \\
\text { the need for improved safety, } \\
\text { including achievable actions that } \\
\text { may have considerable impacts on } \\
\text { maternal morbidity and mortality as } \\
\text { related to cesarean section. }\end{array}$ \\
\hline $\begin{array}{l}\text { General Issues } \\
\text { Presentation }\end{array}$ & $\begin{array}{l}\text { Was the report well-written, } \\
\text { organized, and sufficiently } \\
\text { detailed for critical analysis? } \\
\text { Was the report written in a } \\
\text { manner that makes the findings } \\
\text { accessible to practicing nurses? }\end{array}$ & $\begin{array}{l}\text { The report was easy to follow and } \\
\text { was well organized. Subheadings } \\
\text { were an effective way to outline the } \\
\text { data. }\end{array}$ \\
\hline Researcher credibility & $\begin{array}{l}\text { Do the researchers' clinical, } \\
\text { substantive, or methodologic } \\
\text { qualifications and experience } \\
\text { enhance confidence in the } \\
\text { findings and their } \\
\text { interpretation? }\end{array}$ & $\begin{array}{l}\text { There was information about the } \\
\text { author's qualifications and } \\
\text { experience. }\end{array}$ \\
\hline Summary assessment & $\begin{array}{l}\text { Despite any limitations, do the } \\
\text { study findings appear to be } \\
\text { valid-do you have confidence } \\
\text { in the truth value of the } \\
\text { results? } \\
\text { - Does the study contribute any } \\
\text { meaningful evidence that can } \\
\text { be used in nursing practice or } \\
\text { that is useful to the nursing } \\
\text { discipline? }\end{array}$ & $\begin{array}{l}\text { The study findings appear to be } \\
\text { valid and translatable to other } \\
\text { LMICs with similar healthcare } \\
\text { demographics. } \\
\text { Meaningful changes can be made } \\
\text { based off of the recommendations } \\
\text { of this study. }\end{array}$ \\
\hline
\end{tabular}




\section{Appendix A-10}

Ariyo, P., Trelles, M., Helmand, R., Amir, Y., Hassani, G. H., Mftavyanka, J., . . . Latif, A. (2016). Providing Anesthesia Care in Resource-limited Settings: A 6-year Analysis of Anesthesia Services Provided at Medecins Sans Frontieres Facilities. Anesthesiology, 124(3), 561-569. doi: 10.1097/ALN.0000000000000985

\begin{tabular}{|c|c|c|}
\hline Aspect of the Report & Critiquing Questions & Detailed Critiquing Guidelines \\
\hline Title & $\begin{array}{l}\text { Is the title a good one, } \\
\text { suggesting the key } \\
\text { phenomenon and the group or } \\
\text { community under study? }\end{array}$ & $\begin{array}{l}\text { The title clearly identified the } \\
\text { subject, location, and time frame of } \\
\text { the study. }\end{array}$ \\
\hline Abstract & $\begin{array}{l}\text { Does the abstract clearly and } \\
\text { concisely summarize the main } \\
\text { features of the report? }\end{array}$ & $\begin{array}{l}\text { The abstract outlined all the } \\
\text { components of the study. }\end{array}$ \\
\hline $\begin{array}{l}\text { Introduction } \\
\text { Statement of the } \\
\text { problem }\end{array}$ & $\begin{array}{l}\text { Was the problem stated } \\
\text { unambiguously and is it easy } \\
\text { to identify? } \\
\text { Did the problem statement } \\
\text { build a cogent and persuasive } \\
\text { argument for the new study? } \\
\text { Was the problem significant } \\
\text { for nursing? } \\
\text { Was there a good match } \\
\text { between the research problem } \\
\text { on the one hand and the } \\
\text { paradigm, tradition, and } \\
\text { methods on the other - that is, } \\
\text { was a qualitative approach } \\
\text { appropriate? }\end{array}$ & $\begin{array}{l}\text { The problem was identified clearly } \\
\text { and highlights the challenges of } \\
\text { providing anesthesia in resource- } \\
\text { limited settings. } \\
\text { The problem is significant for nurse } \\
\text { anesthesia practice as results can } \\
\text { provide guidance for practice in } \\
\text { LMICs. } \\
\text { A retrospective analysis was } \\
\text { appropriate for the goals of the } \\
\text { authors. }\end{array}$ \\
\hline Research questions & $\begin{array}{l}\text { Were research questions } \\
\text { explicitly stated? If not, was } \\
\text { their absence justified? } \\
\text { - Were the questions consistent } \\
\text { with the study’s philosophical } \\
\text { basis, underlying tradition, or } \\
\text { ideologic orientation? }\end{array}$ & $\begin{array}{l}\text { The research question was stated } \\
\text { explicitly in the introduction. } \\
\text { The question was consistent with } \\
\text { the study's philosophical basis. }\end{array}$ \\
\hline Literature review & $\begin{array}{l}\text { Did the report adequately } \\
\text { summarize the existing body } \\
\text { of knowledge related to the } \\
\text { problem or phenomenon of } \\
\text { interest? } \\
\text { - Did the literature review } \\
\text { provide a strong basis for the } \\
\text { new study? }\end{array}$ & $\begin{array}{l}\text { A section of "What we already } \\
\text { know" was included in the article, } \\
\text { summarizing previous knowledge } \\
\text { on the topic. } \\
\text { There was no formal literature } \\
\text { review. }\end{array}$ \\
\hline $\begin{array}{l}\text { Conceptual } \\
\text { underpinnings }\end{array}$ & $\begin{array}{l}\text { Were key concepts adequately } \\
\text { defined conceptually? } \\
\text { Was the philosophical basis, } \\
\text { underlying tradition, } \\
\text { conceptual framework, or } \\
\text { ideologic orientation made } \\
\text { explicit and was it appropriate } \\
\text { for the problem? }\end{array}$ & $\begin{array}{l}\text { Key concepts were defined, such as } \\
\text { the operative setting and anesthesia } \\
\text { providers as well as the known } \\
\text { challenges of anesthesia in LMICs. }\end{array}$ \\
\hline
\end{tabular}




\begin{tabular}{|c|c|c|}
\hline $\begin{array}{l}\text { Conceptual/theoretical } \\
\text { framework }\end{array}$ & $\begin{array}{l}\text { - Were key concepts adequately } \\
\text { defined conceptually? } \\
\text { - Was a conceptual/theoretical } \\
\text { framework articulated-and, if } \\
\text { so, was it appropriate? If not, } \\
\text { is the absence of a framework } \\
\text { justified? } \\
\text { - Were the questions/hypotheses } \\
\text { consistent with the framework? }\end{array}$ & $\begin{array}{l}\text { There was no theoretical framework } \\
\text { identified which seemed appropriate } \\
\text { for this type of study. }\end{array}$ \\
\hline $\begin{array}{l}\text { Method } \\
\text { Protection of human } \\
\text { rights }\end{array}$ & $\begin{array}{l}\text { - Were appropriate procedures } \\
\text { used to safe-guard the rights of } \\
\text { study participants? } \\
\text { - Was the study externally } \\
\text { reviewed by an IRB/ethics } \\
\text { review board? } \\
\text { - Was the study designed to } \\
\text { minimize risks and maximize } \\
\text { benefits to participants? }\end{array}$ & $\begin{array}{l}\text { The MSF Ethical Review Board } \\
\text { approved the study. }\end{array}$ \\
\hline Research design & $\begin{array}{l}\text { Was the most rigorous design } \\
\text { used, given the study purpose? } \\
\text { Were appropriate comparisons } \\
\text { made to enhance } \\
\text { interpretability of the findings? } \\
\text { - Was the number of data } \\
\text { collection points appropriate? } \\
\text { Did the design minimize biases } \\
\text { and threats to the internal, } \\
\text { construct, and external validity } \\
\text { of the study (e.g., was blinding } \\
\text { used, was attrition } \\
\text { minimized)? }\end{array}$ & $\begin{array}{l}\text { A retrospective analysis was } \\
\text { appropriate to review surgical } \\
\text { outcomes at MSF facilities. } \\
\text { The number of data points were } \\
\text { appropriate as it included all } \\
\text { surgical missions within the set } \\
\text { timeframe of } 6 \text { years. }\end{array}$ \\
\hline $\begin{array}{l}\text { Population and } \\
\text { sample }\end{array}$ & $\begin{array}{l}\text { Was the population identified? } \\
\text { Was the sample described in } \\
\text { sufficient detail? } \\
\text { Was the best possible sampling } \\
\text { design used to enhance the } \\
\text { sample's representativeness? } \\
\text { Were sampling biases } \\
\text { minimized? } \\
\text { Was the sample size based on } \\
\text { a power analysis? }\end{array}$ & $\begin{array}{l}\text { The population and MSF as an } \\
\text { organization, were adequately } \\
\text { identified and described in detail. } \\
\text { The sample size was not based on a } \\
\text { power analysis. }\end{array}$ \\
\hline $\begin{array}{l}\text { Data collection and } \\
\text { measurement }\end{array}$ & $\begin{array}{l}\text { - Were the operational and } \\
\text { conceptual definitions } \\
\text { congruent? } \\
\text { Were key variables measured } \\
\text { using an appropriate method } \\
\text { (e.g., interviews, observations, } \\
\text { and so on)? } \\
\text { Were specific instruments } \\
\text { adequately described and were } \\
\text { they good choices, given the } \\
\text { study population and the } \\
\text { variables being studied? } \\
\text { Did the report provide } \\
\text { evidence that the data }\end{array}$ & $\begin{array}{l}\text { The authors performed the study } \\
\text { how they conceptualized it. } \\
\text { Key variables were measured using } \\
\text { statistical analysis using a multiple } \\
\text { logistic regression model. } \\
\text { The method in which the findings } \\
\text { were analyzed was well described. } \\
\text { Only complete data sets were used. }\end{array}$ \\
\hline
\end{tabular}




\begin{tabular}{|c|c|c|}
\hline & $\begin{array}{l}\text { collection methods yielded } \\
\text { data that were reliable, valid } \\
\text { and responsive? }\end{array}$ & \\
\hline Procedures & $\begin{array}{l}\text { If there was an intervention, } \\
\text { was it adequately described, } \\
\text { and was it rigorously } \\
\text { developed and implemented? } \\
\text { Did most participants allocated } \\
\text { to the intervention group } \\
\text { actually receive it? Was there } \\
\text { evidence of intervention } \\
\text { fidelity? } \\
\text { Were data collected in a } \\
\text { manner that minimized bias? } \\
\text { Were the staff who collected } \\
\text { data appropriately trained? }\end{array}$ & $\begin{array}{l}\text { There was not an intervention in } \\
\text { this study. } \\
\text { Data was reviewed by the heads of } \\
\text { surgical, anesthesia, gynecology and } \\
\text { emergency medicine units. } \\
\text { Discrepancies were addressed by } \\
\text { contacting the program personnel } \\
\text { involved in data entry. } \\
\text { Bias was minimized by using a } \\
\text { standardized data collection form } \\
\text { for all procedures and at all } \\
\text { facilities worldwide. }\end{array}$ \\
\hline Data Analysis & 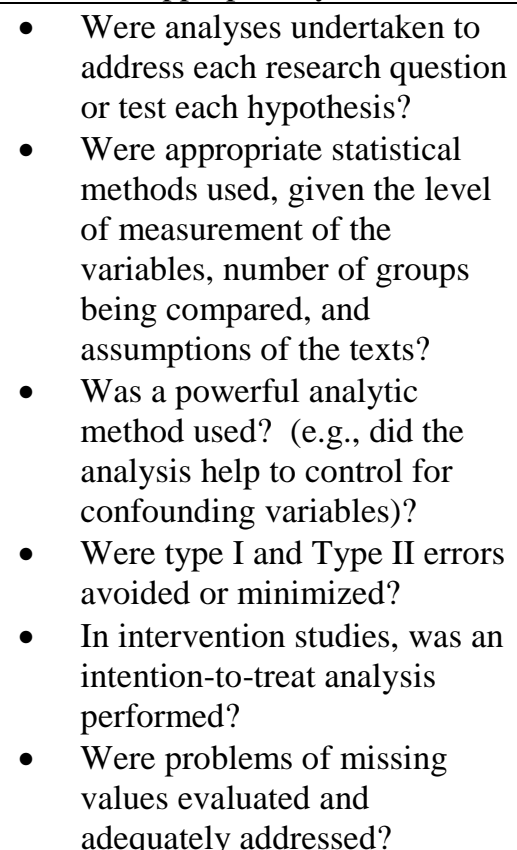 & $\begin{array}{l}\text { The data was well analyzed to } \\
\text { address the research questions. } \\
\text { The statistical method was } \\
\text { appropriate using logistic regression } \\
\text { models. } \\
\text { A powerful analytic method was } \\
\text { used and errors were minimized. } \\
\text { Variables with an association of } \\
\text { P }>0.20 \text { were included in a multiple } \\
\text { logistic regression model for } \\
\text { evaluation. } \\
\text { Stata } 13 \text { was used to analyze the } \\
\text { data. } \\
\text { A sensitivity analysis was } \\
\text { performed. } \\
\text { Authors addressed issues of missing } \\
\text { data }\end{array}$ \\
\hline Findings & $\begin{array}{l}\text { Was information about } \\
\text { statistical significance } \\
\text { presented? Was information } \\
\text { about effect size and precision } \\
\text { of estimates (confidence } \\
\text { intervals) presented? } \\
\text { - Were the findings adequately } \\
\text { summarized, with good use of } \\
\text { tables and figures? } \\
\text { Were findings reported in a } \\
\text { manner that facilitates a meta- } \\
\text { analysis, and with sufficient } \\
\text { information needed for EBP? }\end{array}$ & $\begin{array}{l}\text { A P-value of }<0.05 \text { was used for } \\
\text { statistical significance. } \\
\text { The findings were well summarized } \\
\text { including tables and figures. } \\
\text { The findings suggested the need for } \\
\text { further studies and made } \\
\text { suggestions for change. }\end{array}$ \\
\hline $\begin{array}{l}\text { Discussion } \\
\text { Interpretation of the } \\
\text { findings }\end{array}$ & $\begin{array}{l}\text { Were all major findings } \\
\text { interpreted and discussed } \\
\text { within the context of prior } \\
\text { research and/or the study’s } \\
\text { conceptual framework? }\end{array}$ & $\begin{array}{l}\text { The findings were discussed in the } \\
\text { context of the research questions. } \\
\text { Casual inferences were made and } \\
\text { justified given the results of the } \\
\text { study. }\end{array}$ \\
\hline
\end{tabular}




\begin{tabular}{|c|c|c|}
\hline & $\begin{array}{l}\text { Were casual inferences, if any, } \\
\text { justified? } \\
\text { Was the issue of clinical } \\
\text { significance discussed? } \\
\text { Were interpretations well- } \\
\text { founded and consistent with } \\
\text { the study’s limitations? } \\
\text { Did the report address the issue } \\
\text { of the generalizability of the } \\
\text { findings? }\end{array}$ & $\begin{array}{l}\text { Clinical significance was discussed } \\
\text { and interpretations were } \\
\text { appropriate. } \\
\text { The study was able to generalize its } \\
\text { findings to other LMICs as the data } \\
\text { analyzed was from a number of } \\
\text { different countries. The authors } \\
\text { report possible limitation in that } \\
\text { many surgeries were in emergency } \\
\text { situations so may not be generizable } \\
\text { to chronic needs of LMICs, } \\
\text { however some were performed in } \\
\text { non-conflict settings }\end{array}$ \\
\hline $\begin{array}{l}\text { Implications/ } \\
\text { recommendations }\end{array}$ & $\begin{array}{l}\text { Did the researchers discuss the } \\
\text { implications of the study for } \\
\text { clinical practice or further } \\
\text { research-and were those } \\
\text { implications reasonable and } \\
\text { complete? }\end{array}$ & $\begin{array}{l}\text { The authors reasonably identified } \\
\text { the need for improved safety, } \\
\text { including achievable actions that } \\
\text { may have considerable impacts on } \\
\text { maternal morbidity and mortality as } \\
\text { related to cesarean section. }\end{array}$ \\
\hline $\begin{array}{l}\text { General Issues } \\
\text { Presentation }\end{array}$ & $\begin{array}{l}\text { Was the report well-written, } \\
\text { organized, and sufficiently } \\
\text { detailed for critical analysis? } \\
\text { Was the report written in a } \\
\text { manner that makes the findings } \\
\text { accessible to practicing nurses? }\end{array}$ & $\begin{array}{l}\text { The report was easy to follow and } \\
\text { was well organized. Subheadings } \\
\text { were an effective way to outline the } \\
\text { data. }\end{array}$ \\
\hline Researcher credibility & $\begin{array}{l}\text { Do the researchers' clinical, } \\
\text { substantive, or methodologic } \\
\text { qualifications and experience } \\
\text { enhance confidence in the } \\
\text { findings and their } \\
\text { interpretation? }\end{array}$ & $\begin{array}{l}\text { There was information about the } \\
\text { author's qualifications and } \\
\text { experience. }\end{array}$ \\
\hline Summary assessment & $\begin{array}{l}\text { Despite any limitations, do the } \\
\text { study findings appear to be } \\
\text { valid-do you have confidence } \\
\text { in the truth value of the } \\
\text { results? } \\
\text { - Does the study contribute any } \\
\text { meaningful evidence that can } \\
\text { be used in nursing practice or } \\
\text { that is useful to the nursing } \\
\text { discipline? }\end{array}$ & $\begin{array}{l}\text { The study findings appear to be } \\
\text { valid and translatable to other } \\
\text { LMICs with similar healthcare } \\
\text { demographics. } \\
\text { Meaningful changes can be made } \\
\text { based off of the recommendations } \\
\text { of this study. }\end{array}$ \\
\hline
\end{tabular}




\section{Appendix A-11}

Sobhy, S., Zamora, J., Dharmarajah, K., Arroyo-Manzano, D., Wilson, M., Navaratnarajah, R., ... . Thangaratinam, S. (2016). Anaesthesia-related maternal mortality in low-income and middleincome countries: a systematic review and meta-analysis. Lancet Glob Health, 4(5), e320-327. doi: 10.1016/s2214-109x(16)30003-1

\begin{tabular}{|c|c|}
\hline Critiquing Questions & Critique Responses \\
\hline $\begin{array}{l}\text { 1. Is the review thorough- does it } \\
\text { include all major studies on the } \\
\text { topic? Does it include recent } \\
\text { research (studies published } \\
\text { within previous 2-3 years)? Are } \\
\text { studies from other related } \\
\text { disciplines included, if } \\
\text { appropriate? }\end{array}$ & $\begin{array}{l}\text { The review is thorough and includes all the available } \\
\text { literature up to the time the study was completed. Studies } \\
\text { before } 1990 \text { were excluded from the systematic review. } \\
\text { This time frame is appropriate because of the paucity of } \\
\text { data relating directly to anesthesia as well as the nature of } \\
\text { anesthesia practice in LMICs. Studies from other } \\
\text { disciplines were not included because they would not have } \\
\text { been appropriate. }\end{array}$ \\
\hline $\begin{array}{l}\text { 2. Does the review rely mainly on } \\
\text { primary source research articles? } \\
\text { Are the articles from peer- } \\
\text { reviewed journals? }\end{array}$ & $\begin{array}{l}\text { The review relied on primary source research articles, } \\
\text { however it was not established if these articles were from } \\
\text { peer-reviewed journals. }\end{array}$ \\
\hline $\begin{array}{l}\text { 3. Is the review merely a summary } \\
\text { of existing work, or does it } \\
\text { critically appraise and compare } \\
\text { key studies? Does the review } \\
\text { identify important gaps in the } \\
\text { literature? }\end{array}$ & $\begin{array}{l}\text { The review critically appraised and compared studies not } \\
\text { only by region but also urban vs. rural settings. Gaps in the } \\
\text { literature are discussed by the authors. }\end{array}$ \\
\hline $\begin{array}{l}\text { 4. Is the review well organized? Is } \\
\text { the development of ideas clear? }\end{array}$ & $\begin{array}{l}\text { The review is very well organized and the ideas are } \\
\text { developed clearly with the support of the literature. }\end{array}$ \\
\hline $\begin{array}{l}\text { 5. Does the review use appropriate } \\
\text { language, suggesting the } \\
\text { tentativeness of prior findings? } \\
\text { Is the review objective? Does } \\
\text { the author paraphrase, or is there } \\
\text { an overreliance on quotes from } \\
\text { original sources? }\end{array}$ & $\begin{array}{l}\text { The review uses appropriate language and identifies gaps } \\
\text { and deficiencies in previous findings. It is objective and } \\
\text { uses a variety statistical appraisal tools to support the } \\
\text { author's findings. }\end{array}$ \\
\hline $\begin{array}{l}\text { 6. If the review is part of a research } \\
\text { report for a new study, does the } \\
\text { review support the need for the } \\
\text { study? }\end{array}$ & Not applicable \\
\hline $\begin{array}{l}\text { 7. If it is a review designed to } \\
\text { summarize evidence for clinical } \\
\text { practice, does the review draw } \\
\text { reasonable conclusions about } \\
\text { practice implications? }\end{array}$ & $\begin{array}{l}\text { The review identifies deficiencies in clinical practice and } \\
\text { areas for change that is well supported by the analysis. }\end{array}$ \\
\hline $\begin{array}{l}\text { 8. Was the issue of clinical } \\
\text { significance discussed? Were } \\
\text { interpretations well-founded and } \\
\text { consistent with the study's } \\
\text { limitations? Did the report } \\
\text { address the issue of the } \\
\text { generalizability of the findings? }\end{array}$ & $\begin{array}{l}\text { Clinical significance was discussed and interpretations were } \\
\text { appropriate. The review addressed the risk factors for } \\
\text { maternal and perinatal deaths as related to anesthesia in } \\
\text { LMICs. } \\
\text { Because of breadth of this study, findings were generizable } \\
\text { to other LMICs. }\end{array}$ \\
\hline
\end{tabular}




\section{Appendix A-12}

Epiu, I., Tindimwebwa, J. V., Mijumbi, C., Chokwe, T. M., Lugazia, E., Ndarugirire, F., . . . Dubowitz, G. (2017). Challenges of Anesthesia in Low- and Middle-Income Countries: A Cross-Sectional Survey of Access to Safe Obstetric Anesthesia in East Africa. Anesth Analg, 124(1), 290-299. doi: 10.1213/ane.0000000000001690

\begin{tabular}{|c|c|c|}
\hline Aspect of the Report & Critiquing Questions & Detailed Critiquing Guidelines \\
\hline Title & $\begin{array}{l}\text { Is the title a good one, } \\
\text { suggesting the key } \\
\text { phenomenon and the group or } \\
\text { community under study? }\end{array}$ & $\begin{array}{l}\text { The title clearly identified the } \\
\text { subject, location, and demographics } \\
\text { of the study. }\end{array}$ \\
\hline Abstract & $\begin{array}{l}\text { Does the abstract clearly and } \\
\text { concisely summarize the main } \\
\text { features of the report? }\end{array}$ & $\begin{array}{l}\text { The abstract outlined all the } \\
\text { components of the study. }\end{array}$ \\
\hline $\begin{array}{l}\text { Introduction } \\
\text { Statement of the } \\
\text { problem }\end{array}$ & $\begin{array}{l}\text { Was the problem stated } \\
\text { unambiguously and is it easy } \\
\text { to identify? } \\
\text { Did the problem statement } \\
\text { build a cogent and persuasive } \\
\text { argument for the new study? } \\
\text { Was the problem significant } \\
\text { for nursing? } \\
\text { Was there a good match } \\
\text { between the research problem } \\
\text { on the one hand and the } \\
\text { paradigm, tradition, and } \\
\text { methods on the other - that is, } \\
\text { was a qualitative approach } \\
\text { appropriate? }\end{array}$ & $\begin{array}{l}\text { The problem was identified clearly } \\
\text { and thoroughly and suggests a need } \\
\text { for further study. } \\
\text { The problem is significant for } \\
\text { nursing anesthesia practice as } \\
\text { results can identify deficiencies and } \\
\text { potential areas for change. } \\
\text { A cross-sectional survey was } \\
\text { performed which worked well with } \\
\text { the goals of this study. }\end{array}$ \\
\hline Research questions & $\begin{array}{l}\text { Were research questions } \\
\text { explicitly stated? If not, was } \\
\text { their absence justified? } \\
\text { Were the questions consistent } \\
\text { with the study's philosophical } \\
\text { basis, underlying tradition, or } \\
\text { ideologic orientation? }\end{array}$ & $\begin{array}{l}\text { The research question was explicitly } \\
\text { stated at the end of the introduction. } \\
\text { The question was consistent with } \\
\text { the study's philosophical basis. }\end{array}$ \\
\hline Literature review & $\begin{array}{l}\text { Did the report adequately } \\
\text { summarize the existing body of } \\
\text { knowledge related to the } \\
\text { problem or phenomenon of } \\
\text { interest? } \\
\text { - Did the literature review } \\
\text { provide a strong basis for the } \\
\text { new study? }\end{array}$ & $\begin{array}{l}\text { A brief literature review was } \\
\text { included at the end of the study and } \\
\text { tied in other literature to the topic of } \\
\text { this study well. It also provided a } \\
\text { strong basis for the new study, } \\
\text { although placing the review toward } \\
\text { the beginning of the study would } \\
\text { have provided better context with } \\
\text { viewing the results. }\end{array}$ \\
\hline $\begin{array}{l}\text { Conceptual } \\
\text { underpinnings }\end{array}$ & $\begin{array}{l}\text { Were key concepts adequately } \\
\text { defined conceptually? } \\
\text { - Was the philosophical basis, } \\
\text { underlying tradition, } \\
\text { conceptual framework, or } \\
\text { ideologic orientation made }\end{array}$ & $\begin{array}{l}\text { The conceptual framework was } \\
\text { included and defined toward the end } \\
\text { of the study. }\end{array}$ \\
\hline
\end{tabular}




\begin{tabular}{|c|c|c|}
\hline & $\begin{array}{l}\text { explicit and was it appropriate } \\
\text { for the problem? }\end{array}$ & \\
\hline $\begin{array}{l}\text { Conceptual/theoretical } \\
\text { framework }\end{array}$ & $\begin{array}{l}\text { - Were key concepts adequately } \\
\text { defined conceptually? } \\
\text { - Was a conceptual/theoretical } \\
\text { framework articulated-and, if } \\
\text { so, was it appropriate? If not, } \\
\text { is the absence of a framework } \\
\text { justified? } \\
\text { - Were the questions/hypotheses } \\
\text { consistent with the framework? }\end{array}$ & $\begin{array}{l}\text { The three-delays framework was } \\
\text { used in the study. It was explained } \\
\text { adequately and related it to the } \\
\text { context of this study. }\end{array}$ \\
\hline $\begin{array}{l}\text { Method } \\
\text { Protection of human } \\
\text { rights }\end{array}$ & $\begin{array}{l}\text { Were appropriate procedures } \\
\text { used to safe-guard the rights of } \\
\text { study participants? } \\
\text { Was the study externally } \\
\text { reviewed by an IRB/ethics } \\
\text { review board? } \\
\text { - Was the study designed to } \\
\text { minimize risks and maximize } \\
\text { benefits to participants? }\end{array}$ & $\begin{array}{l}\text { Ethical approval was obtained from } \\
\text { Makere University school of } \\
\text { Medicine Research and Ethics } \\
\text { Committee, the Uganda National } \\
\text { Council for Science and Technology } \\
\text { Ethics Committee, and hospital } \\
\text { ethics committees for participating } \\
\text { hospitals. } \\
\text { Informed consent was obtained } \\
\text { from all individuals partaking in the } \\
\text { study. }\end{array}$ \\
\hline Research design & $\begin{array}{l}\text { Was the most rigorous design } \\
\text { used, given the study purpose? } \\
\text { Were appropriate comparisons } \\
\text { made to enhance } \\
\text { interpretability of the findings? } \\
\text { - Was the number of data } \\
\text { collection points appropriate? } \\
\text { Did the design minimize biases } \\
\text { and threats to the internal, } \\
\text { construct, and external validity } \\
\text { of the study (e.g., was blinding } \\
\text { used, was attrition minimized)? }\end{array}$ & $\begin{array}{l}\text { A cross-sectional survey was } \\
\text { appropriate for the author's goals. } \\
\text { The structured questionnaire was } \\
\text { based on World Federation of } \\
\text { Societies of Anesthesiologists } \\
\text { (WFSA) guidelines, which included } \\
\text { demographic, administrative, pre- } \\
\text { anesthetic, intraoperative and post- } \\
\text { anesthetic variables. } \\
\text { A copy of the questionnaire was not } \\
\text { provided for review. }\end{array}$ \\
\hline $\begin{array}{l}\text { Population and } \\
\text { sample }\end{array}$ & $\begin{array}{l}\text { - Was the population identified? } \\
\text { Was the sample described in } \\
\text { sufficient detail? } \\
\text { - Was the best possible sampling } \\
\text { design used to enhance the } \\
\text { sample's representativeness? } \\
\text { Were sampling biases } \\
\text { minimized? } \\
\text { Was the sample size based on a } \\
\text { power analysis? }\end{array}$ & $\begin{array}{l}\text { The population was adequately } \\
\text { identified and described in great } \\
\text { detail. } \\
\text { The sample size was calculated } \\
\text { using the formula for dichotomous } \\
\text { variables with a } 95 \% \text { confidence } \\
\text { interval. } \\
\text { The sample was stratified according } \\
\text { to the number of physician and non- } \\
\text { physician anesthetists available in } \\
\text { each hospital and the individuals } \\
\text { interviewed were selected by simple } \\
\text { random sampling. } \\
\text { Bias relating to the sample size was } \\
\text { addressed by the authors. }\end{array}$ \\
\hline $\begin{array}{l}\text { Data collection and } \\
\text { measurement }\end{array}$ & $\begin{array}{l}\text { - Were the operational and } \\
\text { conceptual definitions } \\
\text { congruent? } \\
\text { - Were key variables measured } \\
\text { using an appropriate method }\end{array}$ & $\begin{array}{l}\text { The authors performed the study } \\
\text { how they conceptualized it } \\
\text { Qualitative and quantitative data } \\
\text { were collected by investigators. } \\
\text { Interviews were conducted with the } \\
\text { head of the National Society of }\end{array}$ \\
\hline
\end{tabular}




\begin{tabular}{|c|c|c|}
\hline & $\begin{array}{l}\text { (e.g., interviews, observations, } \\
\text { and so on)? } \\
\text { Were specific instruments } \\
\text { adequately described and were } \\
\text { they good choices, given the } \\
\text { study population and the } \\
\text { variables being studied? } \\
\text { Did the report provide } \\
\text { evidence that the data } \\
\text { collection methods yielded } \\
\text { data that were reliable, valid } \\
\text { and responsive? }\end{array}$ & $\begin{array}{l}\text { Anesthesia and a representative of } \\
\text { the Ministry of Health to determine } \\
\text { the distribution of anesthetists in the } \\
\text { country, challenges faced in } \\
\text { delivery of anesthesia, and possible } \\
\text { solutions. }\end{array}$ \\
\hline Procedures & $\begin{array}{l}\text { If there was an intervention, } \\
\text { was it adequately described, } \\
\text { and was it rigorously } \\
\text { developed and implemented? } \\
\text { Did most participants allocated } \\
\text { to the intervention group } \\
\text { actually receive it? Was there } \\
\text { evidence of intervention } \\
\text { fidelity? } \\
\text { Were data collected in a } \\
\text { manner that minimized bias? } \\
\text { Were the staff who collected } \\
\text { data appropriately trained? }\end{array}$ & $\begin{array}{l}\text { The participants were interviewed } \\
\text { by the principal investigator. } \\
\text { The authors stratified according to } \\
\text { the number of physician and non- } \\
\text { physician anesthetists available in } \\
\text { each hospital and the individuals } \\
\text { interviewed were selected by simple } \\
\text { random sampling. }\end{array}$ \\
\hline Data Analysis & $\begin{array}{l}\text { Were analyses undertaken to } \\
\text { address each research question } \\
\text { or test each hypothesis? } \\
\text { Were appropriate statistical } \\
\text { methods used, given the level } \\
\text { of measurement of the } \\
\text { variables, number of groups } \\
\text { being compared, and } \\
\text { assumptions of the texts? } \\
\text { Was a powerful analytic } \\
\text { method used? (e.g., did the } \\
\text { analysis help to control for } \\
\text { confounding variables)? } \\
\text { Were type I and Type II errors } \\
\text { avoided or minimized? } \\
\text { In intervention studies, was an } \\
\text { intention-to-treat analysis } \\
\text { performed? } \\
\text { Were problems of missing } \\
\text { values evaluated and } \\
\text { adequately addressed? }\end{array}$ & $\begin{array}{l}\text { The data were appropriately } \\
\text { analyzed to address the research } \\
\text { question. } \\
\text { The statistical method was } \\
\text { appropriate given the goals of the } \\
\text { authors. } \\
\text { A significance level of }<0.05 \text { was } \\
\text { used. }\end{array}$ \\
\hline Findings & $\begin{array}{l}\text { - Was information about } \\
\text { statistical significance } \\
\text { presented? Was information } \\
\text { about effect size and precision } \\
\text { of estimates (confidence } \\
\text { intervals) presented? } \\
\text { - Were the findings adequately } \\
\text { summarized, with good use of } \\
\text { tables and figures? }\end{array}$ & $\begin{array}{l}\text { Statistical significance and } \\
\text { confidence intervals were presented } \\
\text { in this study. } \\
\text { The findings were well summarized } \\
\text { including tables and figures. } \\
\text { The findings could be used in future } \\
\text { studies, including meta- analysis as } \\
\text { well as be used for EBP. }\end{array}$ \\
\hline
\end{tabular}




\begin{tabular}{|c|c|c|}
\hline & $\begin{array}{l}\text { Were findings reported in a } \\
\text { manner that facilitates a meta- } \\
\text { analysis, and with sufficient } \\
\text { information needed for EBP? }\end{array}$ & \\
\hline $\begin{array}{l}\text { Discussion } \\
\text { Interpretation of the } \\
\text { findings }\end{array}$ & $\begin{array}{l}\text { Were all major findings } \\
\text { interpreted and discussed } \\
\text { within the context of prior } \\
\text { research and/or the study’s } \\
\text { conceptual framework? } \\
\text { - Were casual inferences, if any, } \\
\text { justified? } \\
\text { - Was the issue of clinical } \\
\text { significance discussed? } \\
\text { Were interpretations well- } \\
\text { founded and consistent with } \\
\text { the study’s limitations? } \\
\text { Did the report address the issue } \\
\text { of the generalizability of the } \\
\text { findings? }\end{array}$ & $\begin{array}{l}\text { The findings were discussed in the } \\
\text { context of the research question. } \\
\text { Casual inferences were made and } \\
\text { justified given the results of the } \\
\text { study. } \\
\text { Clinical significance was discussed } \\
\text { and interpretations were } \\
\text { appropriate. The results covered a } \\
\text { broad range of topics relating to } \\
\text { anesthesia in LMICs. } \\
\text { The results were discussed within } \\
\text { the limits of the study and addressed } \\
\text { by the author. } \\
\text { The study did attempt to generalize } \\
\text { its findings to other LMICs. }\end{array}$ \\
\hline $\begin{array}{l}\text { Implications/ } \\
\text { recommendations }\end{array}$ & $\begin{array}{l}\text { Did the researchers discuss the } \\
\text { implications of the study for } \\
\text { clinical practice or further } \\
\text { research-and were those } \\
\text { implications reasonable and } \\
\text { complete? }\end{array}$ & $\begin{array}{l}\text { The authors reasonably identified } \\
\text { deficiencies in obstetric anesthesia } \\
\text { care and provided appropriate } \\
\text { recommendations. }\end{array}$ \\
\hline $\begin{array}{l}\text { General Issues } \\
\text { Presentation }\end{array}$ & $\begin{array}{l}\text { Was the report well-written, } \\
\text { organized, and sufficiently } \\
\text { detailed for critical analysis? } \\
\text { Was the report written in a } \\
\text { manner that makes the findings } \\
\text { accessible to practicing nurses? }\end{array}$ & $\begin{array}{l}\text { The report was easy to follow and } \\
\text { the data were clearly outlined and } \\
\text { made available for critical analysis }\end{array}$ \\
\hline Researcher credibility & $\begin{array}{l}\text { Do the researchers' clinical, } \\
\text { substantive, or methodologic } \\
\text { qualifications and experience } \\
\text { enhance confidence in the } \\
\text { findings and their } \\
\text { interpretation? } \\
\end{array}$ & $\begin{array}{l}\text { The researchers' qualifications } \\
\text { enhance confidence in the findings } \\
\text { of the study. }\end{array}$ \\
\hline Summary assessment & $\begin{array}{l}\text { Despite any limitations, do the } \\
\text { study findings appear to be } \\
\text { valid-do you have confidence } \\
\text { in the truth value of the } \\
\text { results? } \\
\text { - Does the study contribute any } \\
\text { meaningful evidence that can } \\
\text { be used in nursing practice or } \\
\text { that is useful to the nursing } \\
\text { discipline? }\end{array}$ & $\begin{array}{l}\text { The study findings appear to be } \\
\text { valid and translatable to other } \\
\text { LMICs with similar healthcare } \\
\text { demographics. } \\
\text { Meaningful changes can be made } \\
\text { based off of the recommendations } \\
\text { of this study. }\end{array}$ \\
\hline
\end{tabular}




\section{Appendix B-1}

Fenton, P. M., Whitty, C. J., \& Reynolds, F. (2003). Caesarean section in Malawi: prospective study of early maternal and perinatal mortality. Bmj, 327(7415), 587. doi:

10.1136/bmj.327.7415.587

\begin{tabular}{|c|c|}
\hline Objective & $\begin{array}{l}\text { To examine potentially modifiable factors that may influence the high maternal } \\
\text { and perinatal mortality associated with cesarean section in Malawi }\end{array}$ \\
\hline Findings & 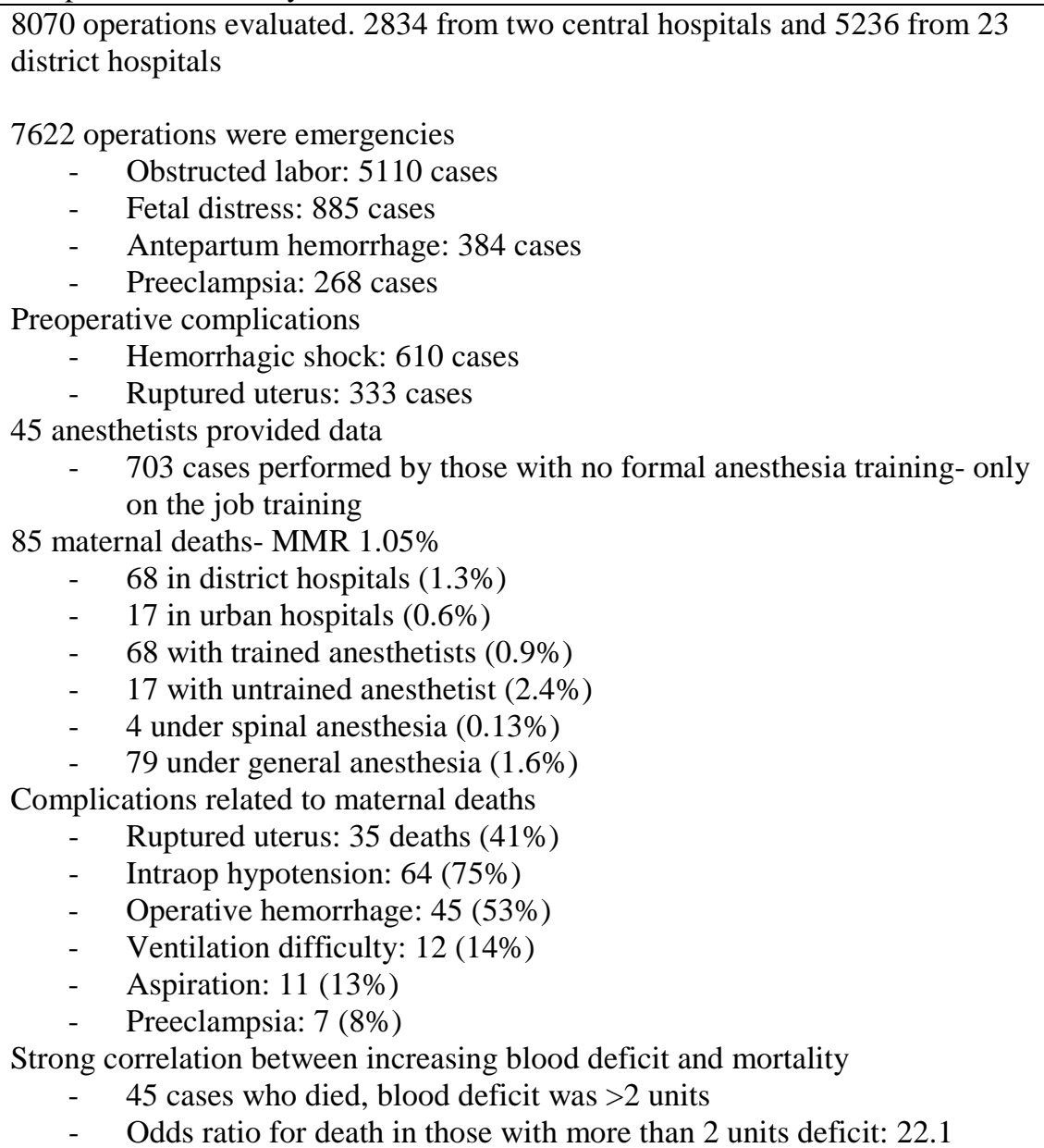 \\
\hline $\begin{array}{l}\text { Anesthesia-related } \\
\text { causes of morbidity } \\
\text { and mortality }\end{array}$ & $\begin{array}{l}\text { The level of training of the anesthetist- not all those giving anesthetics were } \\
\text { formally trained to do so } \\
\text { Blood loss- greater loss was strongly associated with mortality. } \\
\text { Type of anesthesia- spinal anesthesia may be safer than GA among women } \\
\text { without depletion of blood volume. }\end{array}$ \\
\hline $\begin{array}{l}\text { Suggestions/ } \\
\text { interventions to } \\
\text { reduce MMR }\end{array}$ & $\begin{array}{l}\text { Better fluid resuscitation } \\
\text { Training in spinal anesthesia } \\
\text { Training of anesthesia providers to manage care in the ward postoperatively and } \\
\text { provide basic resuscitation }\end{array}$ \\
\hline
\end{tabular}




\section{Appendix B-2}

Glenshaw, M., \& Madzimbamuto, F. D. (2005). Anaesthesia associated mortality in a district hospital in Zimbabwe: 1994 to 2001. Cent Afr J Med, 51(3-4), 39-44.

\begin{tabular}{|l|c|}
\hline Objective & To describe anesthetic associated mortality in a district hospital in Zimbabwe \\
\hline Findings & $\begin{aligned} 77 \text { maternal patients died in the hospital between 1994-2001 } \\
-\quad \text { MMR= 360:100,000 }\end{aligned}$ \\
& $\begin{aligned} 7 \text { deaths } & \text { within 24 hours of anesthesia } \\
- & \text { All had emergency surgery }\end{aligned}$ \\
$-\quad$ MMR= 1:334
\end{tabular}




\section{Appendix B-3}

Enohumah, K. O., \& Imarengiaye, C. O. (2006). Factors associated with anaesthesia-related maternal mortality in a tertiary hospital in Nigeria. Acta Anaesthesiol Scand, 50(2), 206-210. doi: 10.1111/j.1399-6576.2006.00945.x

\begin{tabular}{|c|c|}
\hline Objective & $\begin{array}{l}\text { To determine the incidence of anesthesia-related maternal mortality, to analyze } \\
\text { the causes and to suggest measures to improve anesthetic safety to parturients }\end{array}$ \\
\hline Findings & 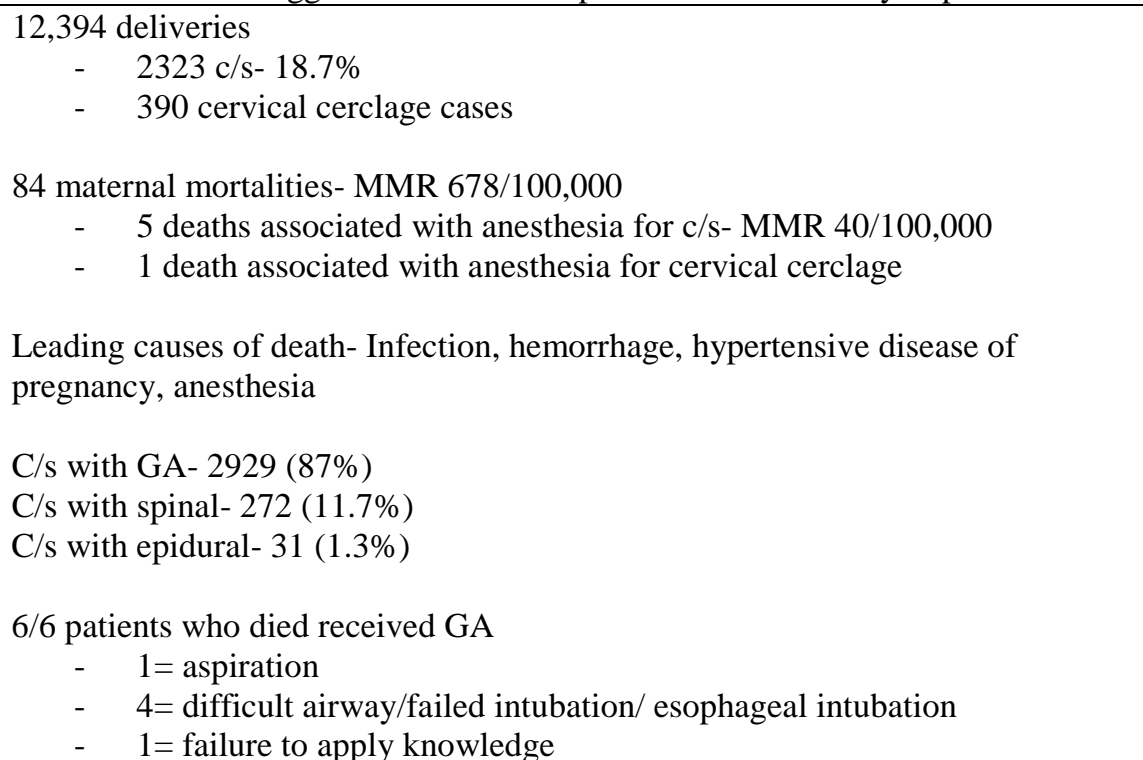 \\
\hline $\begin{array}{l}\text { Anesthesia-related } \\
\text { causes of morbidity } \\
\text { and mortality }\end{array}$ & $\begin{array}{l}\text { Anesthetic risk factors associated with maternal mortality- regurgitation/ } \\
\text { aspiration of gastric contents, inadequate supervision of trainees, difficult airway } \\
\text { management/ failed intubation, failure to apply knowledge }\end{array}$ \\
\hline
\end{tabular}




\section{Appendix B-4}

Khan, K. S., Wojdyla, D., Say, L., Gülmezoglu, A. M., \& Van Look, P. F. A. (2006). WHO analysis of causes of maternal death: a systematic review. The Lancet, 367(9516), 10661074. doi: 10.1016/s0140-6736(06)68397-9

\begin{tabular}{|l|l|}
\hline Objective & $\begin{array}{l}\text { To ascertain and identify gaps in regional coverage and explore the extent to } \\
\text { which countries' development status, geographical location, and dataset's } \\
\text { methodological features explain variable distribution of causes of death }\end{array}$ \\
\hline Findings & $\begin{array}{r}\text { 34 articles reviewed } \\
\text { Joint causes of death, regional differences: } \\
-\quad \text { Hemorrhage is leading cause of death in Africa and Asia (>30\%) } \\
-\quad \text { Hypertensive disorders leading cause of death in Latin America and the } \\
\text { Caribbean }\end{array}$ \\
& $\begin{array}{l}\text { HIV/AIDS causing 6\% of deaths in Africa } \\
-\quad \text { Anemia and obstructive labor causing 10\% of deaths in Asia }\end{array}$ \\
\hline $\begin{array}{l}\text { Anesthesia- } \\
\text { related causes of } \\
\text { morbidity and } \\
\text { mortality }\end{array}$ & $\begin{array}{l}\text { Compared with developed countries, sepsis was significantly more frequent in } \\
\text { Africa, Asia and Latin America and the Caribbean } \\
\text { disorders }\end{array}$ \\
\hline $\begin{array}{l}\text { Suggestions/ } \\
\text { interventions to } \\
\text { reduce MMR }\end{array}$ & $\begin{array}{l}\text { The contribution of sepsis and HIV in Africa, anemia in Asia, and abortion in } \\
\text { Latin America and the Caribbean are more region specific }\end{array}$ \\
\hline
\end{tabular}




\section{Appendix B-5}

Hodges, S. C., Mijumbi, C., Okello, M., McCormick, B. A., Walker, I. A., \& Wilson, I. H. (2007). Anaesthesia services in developing countries: defining the problems. Anaesthesia, 62(1), 4-11. doi: 10.1111/j.1365-2044.2006.04907.x

\begin{tabular}{|c|c|}
\hline Objective & To define the difficulties in providing anesthesia in Uganda \\
\hline Findings & 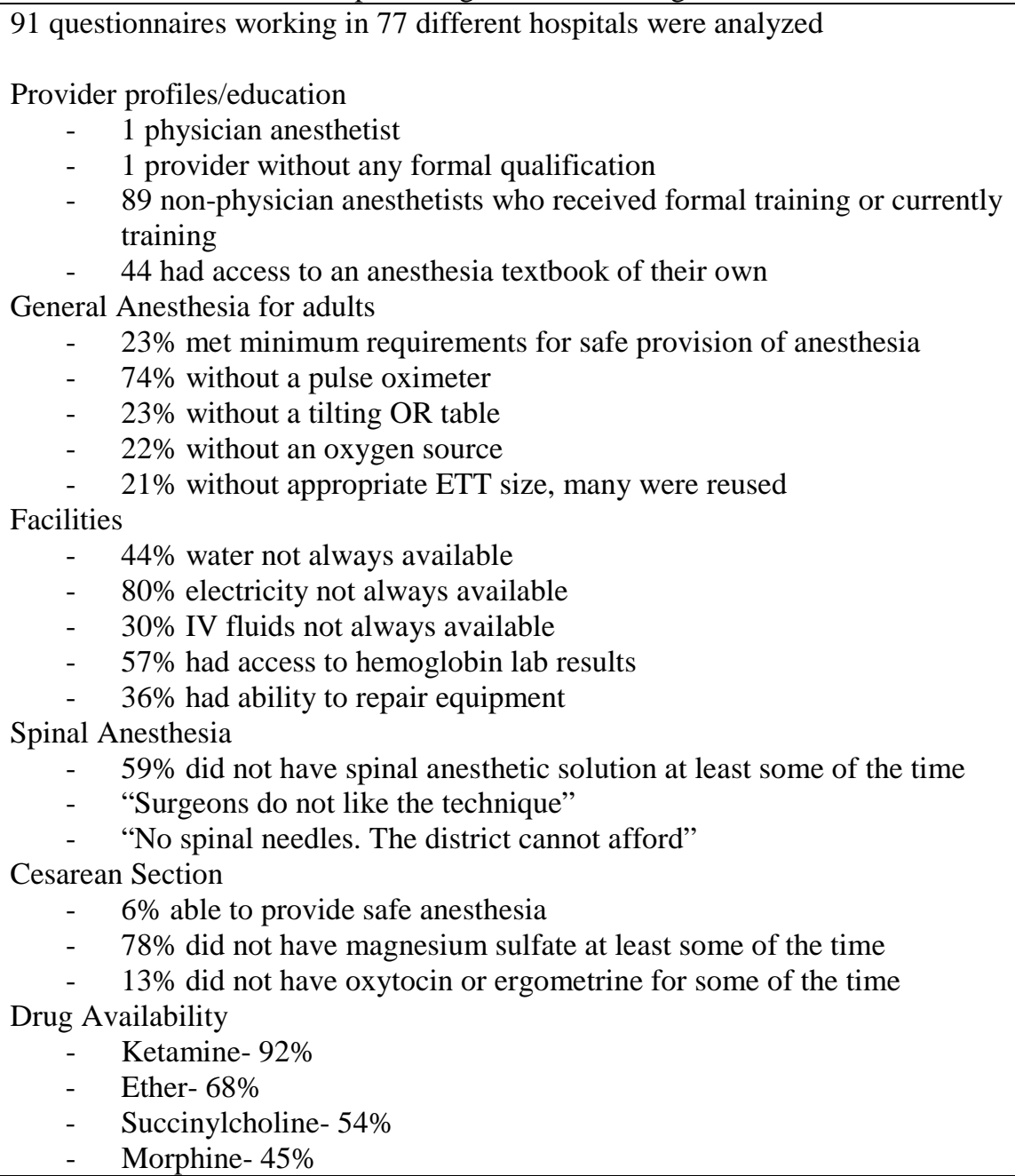 \\
\hline $\begin{array}{l}\text { Anesthesia-related } \\
\text { causes of morbidity } \\
\text { and mortality }\end{array}$ & All these deficiencies contribute to the MMR \\
\hline $\begin{array}{l}\text { Suggestions/ } \\
\text { interventions to } \\
\text { reduce MMR }\end{array}$ & $\begin{array}{l}\text { Ensuring products, such as Ketamine and Halothane, are still available for use } \\
\text { despite their limited profitability to companies, is crucial for anesthesia care in } \\
\text { LMICs } \\
\text { Increasing political awareness of the issues at local and national levels; } \\
\text { increasing numbers of trained personnel; defining local and national standards of } \\
\text { care; improving logistical arrangements for the supply of equipment and drugs; } \\
\text { consideration of the design of healthcare systems and the need for capital } \\
\text { investment in pulse-oximetry }\end{array}$ \\
\hline
\end{tabular}




\section{Appendix B-6}

Ajuzieogu, O. V., Ezike, H. A., Amucheazi, A. O., \& Enwereji, J. (2011). A retrospective study of the outcome of cesarean section for women with severe pre-eclampsia in a third world setting. Saudi J Anaesth, 5(1), 15-18. doi: 10.4103/1658-354x.76480

\begin{tabular}{|c|c|}
\hline Objective & $\begin{array}{l}\text { To compare the outcome of subarachnoid block and general anesthesia in c/s for } \\
\text { women with severe preeclampsia }\end{array}$ \\
\hline Findings & $\begin{array}{ll}37 / 116 & \text { (38.5\%) received subarachnoid block } \\
- & 11 \text { emergencies } \\
- & 2 \text { maternal deaths } \\
- & 1 \text { anesthetic complications } \\
- & \text { No significance found } \\
59 / 116 & (61.5 \%) \text { received GA } \\
- & 19 \text { emergencies } \\
- & 7 \text { maternal deaths } \\
- & 5 \text { anesthetic complications } \\
- & \text { No significance found } \\
\text { APGAR scores }<7 \text { at } 1 \text { minute: } \\
-\quad 10 \text { babies in subarachnoid group } \\
-\quad 33 \text { babies in GA group } \\
-\quad \text { Significance found } \\
\text { APGAR scores }<7 \text { at } 5 \text { minutes: } \\
-\quad 5 \text { babies from subarachnoid group } \\
-\quad 21 \text { babies in GA group } \\
-\quad \text { Significance found }\end{array}$ \\
\hline $\begin{array}{l}\text { Anesthesia- } \\
\text { related causes of } \\
\text { morbidity and } \\
\text { mortality }\end{array}$ & $\begin{array}{l}\text { Subarachnoid block- severe hypotension unresponsive to resuscitatory measures } \\
\text { GA- wrong intubations, Mendelson's syndrome, and unexplained drug reactions }\end{array}$ \\
\hline $\begin{array}{l}\text { Suggestions/ } \\
\text { interventions to } \\
\text { reduce MMR }\end{array}$ & $\begin{array}{l}\text { The absence of studies from similar study environments showing the safety of } \\
\text { subarachnoid blocks over GA for severe preeclampsia may contribute to the larger } \\
\text { percentage of GA procedures in this study. }\end{array}$ \\
\hline
\end{tabular}




\section{Appendix B-7}

Anderson, R. E., Ahn, R., Nelson, B. D., Chavez, J., de Redon, E., \& Burke, T. (2014). Defining the anesthesia gap for reproductive health procedures in resource-limited settings. Int $J$ Gynaecol Obstet, 127(3), 229-233. doi: 10.1016/j.ijgo.2014.06.023

\begin{tabular}{|c|c|}
\hline Objective & $\begin{array}{l}\text { To more clearly understand the individual components of the anesthesia gap } \\
\text { pertaining to reproductive health surgeries and procedures in resource-limited } \\
\text { settings }\end{array}$ \\
\hline Findings & $\begin{array}{l}\text { 14 articles met the inclusion criteria and were reviewed } \\
\text { Three common themes emerged in the articles: } \\
\text { 1. Lack of infrastructure } \\
\text { - } \quad \text { Lapses in electricity, intermittent running water prevent the use of } \\
\text { equipment } \\
\text { - } \quad \text { Lack of transportation, roads, poor community education, preparedness, } \\
\text { multiple effects of poverty } \\
\text { 2. Lack of equipment and supplies } \\
\text { - Essential surgical equipment and supplies, airway management devices, } \\
\text { antibiotics and medications for intubation, anesthesia and analgesia } \\
\text { - All hospitals in Uganda were missing WHO defined essential } \\
\text { equipment- similar results in Rwanda and Ethiopia } \\
\text { 3. Lack of trained personnel } \\
\text { - } \quad \text { Uganda has } 0.05 \text { anesthetists per 100,000, Rwanda 0.09, Ethiopia } 0.02 \\
\text { - Political instability, corruption, emigration, devastation of labor force by } \\
\text { disease contribute to this } \\
\text { - Most anesthesia for c/s is administered by non-physicians with 1-3 years } \\
\text { - of training } \\
\text { Training often does not include mentorship, continuing education or } \\
\text { professional development }\end{array}$ \\
\hline $\begin{array}{l}\text { Anesthesia-related } \\
\text { causes of } \\
\text { morbidity and } \\
\text { mortality }\end{array}$ & All of these deficiencies contribute to the MMR \\
\hline $\begin{array}{l}\text { Suggestions/ } \\
\text { interventions to } \\
\text { reduce MMR }\end{array}$ & $\begin{array}{l}\text { New and innovative ideas are required to address the findings- must be rapid, } \\
\text { high-impact and cost effective } \\
\text { Development of affordable monitoring devices and simple but safe clinical } \\
\text { protocols that take into account resource-limited challenges }\end{array}$ \\
\hline
\end{tabular}




\section{Appendix B-8}

Hoyler, M., Finlayson, S. R., McClain, C. D., Meara, J. G., \& Hagander, L. (2014). Shortage of doctors, shortage of data: a review of the global surgery, obstetrics, and anesthesia workforce literature. World J Surg, 38(2), 269-280. doi: 10.1007/s00268-013-2324-y

\begin{tabular}{|c|c|}
\hline Objective & $\begin{array}{l}\text { To summarize the existing literature regarding the number of surgeons, } \\
\text { obstetricians, and anesthesiologists in LMICs, and to describe the potential utility } \\
\text { of robust national data regarding the global surgery workforce }\end{array}$ \\
\hline Findings & $\begin{array}{l}38 \text { papers analyzed, } 44 \text { countries represented } \\
-\quad \text { No published data for } 23 \text { of } 57 \text { identified by WHO as having a workforce } \\
\text { crisis } \\
\text { Anesthesiologist density 0-4.9:100,000 } \\
\text { - } \quad \text { GDP per capita significantly correlated with total physician density } \\
\quad(\mathrm{p}=0.004)\end{array}$ \\
\hline $\begin{array}{l}\text { Anesthesia- } \\
\text { related causes of } \\
\text { morbidity and } \\
\text { mortality }\end{array}$ & Shortage in anesthesiologists could lead to inadequate care, increasing the MMR \\
\hline $\begin{array}{l}\text { Suggestions/ } \\
\text { interventions to } \\
\text { reduce MMR }\end{array}$ & $\begin{array}{l}\text { A need for comprehensive surgical workforce data at the national level to identify } \\
\text { factors that correlate and potentially contribute to surgical workforce shortages, } \\
\text { possible consequences of inadequate workforce, such as the MMR } \\
\text { This information would help researchers and policy makers identify the cause of } \\
\text { workforce crisis, inform international responses to the crisis, and establish a new } \\
\text { metric for assessing the strength of healthcare systems } \\
\text { Help to identify the extent and impact anesthesiologist migration has on the } \\
\text { workforce crisis } \\
\text { Numerical evidence of a dwindling workforce can reshape high-income countries } \\
\text { approaches to international recruitment from LMICs }\end{array}$ \\
\hline
\end{tabular}




\section{Appendix B-9}

Ologunde, R., Vogel, J. P., Cherian, M. N., Sbaiti, M., Merialdi, M., \& Yeats, J. (2014). Assessment of cesarean delivery availability in 26 low- and middle-income countries: a cross-sectional study. Am J Obstet Gynecol, 211(5), 504.e501-504.e512. doi: 10.1016/j.ajog.2014.05.022

\begin{tabular}{|c|c|}
\hline Objective & $\begin{array}{l}\text { To quantify cesarean delivery capacity in health facilities in LMICs based on } \\
\text { availability of the procedure, infrastructure, human resources and reasons for } \\
\text { referral }\end{array}$ \\
\hline Findings & $\begin{array}{cl}719 \text { health facilities were included } \\
\text { - } & 14 \text { African countries } \\
\text { - } & 5 \text { Western Pacific countries } \\
\text { - } & 3 \text { Southeast Asian countries } \\
\text { - } & 2 \text { Eastern Mediterranean countries } \\
\text { - } & 2 \text { North American countries } \\
\text { - } & 531 \text { facilities performed C/S } \\
\text { Referral } & \\
\text { - } & 126 \text { referred the procedure to another facility } \\
\text { - } & \text { Private/ NGO/ mission hospitals provided most C/S } \\
\text { - } & \text { Referral most common in health centers } \\
\text { - } & \text { Most common reasons for referral: lack of skills, nonfunctioning } \\
\text { Essential surgical elements } & \text { equipment, lack of supplies/drugs } \\
\text { - } & \text { Consistent availability of an oxygen supply: 78.8\% } \\
\text { - } & \text { An anesthesia machine: 66.7\% } \\
\text { - } & \text { A blood bank: 39.8\% } \\
\text { - } & \text { A statistically significant difference was found in the availability of } \\
& \text { essential surgical elements between facilities performing and those not } \\
\text { Human } & \text { Rerforming but referring C/S } \\
\text { - } & \text { Nurses or non-physician anesthetists were most common provider of } \\
& \text { anesthesia } \\
\text { - } & \text { For those referring due to lack of skills, only } 4 \text { had an anesthesiologist } \\
& \text { and only } 6 \text { had one non-physician provider } \\
\text { - } & \text { 251 facilities reported performing C/S without an anesthesia provider }\end{array}$ \\
\hline $\begin{array}{l}\text { Anesthesia- } \\
\text { related causes of } \\
\text { morbidity and } \\
\text { mortality }\end{array}$ & $\begin{array}{l}\text { Lack of skills and nonfunctioning equipment were found to be a major barrier to } \\
\text { provision of C/S } \\
\text { In hospitals performing C/S, data demonstrated a Lack of essential equipment, } \\
\text { skilled anesthesia providers, obstetric and surgical care providers } \\
\text { Oxygen is crucial for safe surgical procedures and emergency resuscitation- a } \\
\text { large number did not have reliable source of oxygen } \\
\text { Postpartum hemorrhage is a leading cause of maternal death and lack of a blood } \\
\text { bank is an urgent priority } \\
\begin{array}{l}\text { Lack of specialists in obstetrics may have significant adverse effects } \\
-\quad>50 \% \text { of all facilities did not report the presence of any type of } \\
\text { anesthesia provider }\end{array}\end{array}$ \\
\hline $\begin{array}{l}\text { Suggestions/ } \\
\text { interventions to } \\
\text { reduce MMR }\end{array}$ & $\begin{array}{l}\text { Efforts to increase surgical and obstetric capacity and availability of C/S need to } \\
\text { focus on addressing deficiencies in key infrastructure items and meeting the } \\
\text { training needs of the healthcare workforce }\end{array}$ \\
\hline
\end{tabular}




\section{Appendix B-10}

Ariyo, P., Trelles, M., Helmand, R., Amir, Y., Hassani, G. H., Mftavyanka, J., . . Latif, A. (2016). Providing Anesthesia Care in Resource-limited Settings: A 6-year Analysis of Anesthesia Services Provided at Medecins Sans Frontieres Facilities. Anesthesiology, 124(3), 561-569. doi: 10.1097/ALN.0000000000000985

\begin{tabular}{|c|c|}
\hline Objective & $\begin{array}{l}\text { To review the anesthesia care provided by various missions coordinated by MSF } \\
\text { between 2008-2014 } \\
\text { To ascertain the types and outcomes of commonly performed anesthesia } \\
\text { techniques }\end{array}$ \\
\hline Findings & $\begin{array}{l}\text { 79,383 anesthetics were performed } \\
\text { Spinal anesthesia was most common- 34,413 procedures (45.65\%) } \\
\text { GA was second most common- 25,566 procedures (33.85\%) } \\
\text { Elective cases- 10,062 (13.31\%) } \\
\text { Time sensitive- 22,651 (30\%) } \\
\text { Emergent cases- 42,823 (56.69\%) } \\
\text { Most common procedures was c/s- 26,091 (34.54\%) } \\
\text { Spinal anesthesia most common for obstetric/gynecologic/ urologic procedures- } \\
\text { 23,671 (69.45\%) } \\
\text { Perioperative mortality 0.25\% } \\
\text { Emergent cases compared to elective- AOR } 15.86 \\
\text { Obstetric/GYN/urologic compared to minor surgery- AOR } 3.82 \\
\text { Spinal anesthesia compared to GETA- AOR 0.10 }\end{array}$ \\
\hline $\begin{array}{l}\text { Anesthesia- } \\
\text { related causes of } \\
\text { morbidity and } \\
\text { mortality }\end{array}$ & $\begin{array}{l}\text { Spinal anesthesia was most commonly used technique, and safest. } \\
\text { Popularity due to safety profile, efficacy in providing surgical anesthesia, and } \\
\text { minimal equipment requirements } \\
\text { GA without intubation was second safest- use of ketamine improves outcomes } \\
\text { Specialty procedures were associated with higher mortality- low volume, lack of } \\
\text { expertise }\end{array}$ \\
\hline $\begin{array}{l}\text { Suggestions/ } \\
\text { interventions to } \\
\text { reduce MMR }\end{array}$ & $\begin{array}{l}\text { Keep delivery of care simple } \\
\text { Streamline anesthetics to a basic and conservative list of drugs and procedures } \\
\text { that are sustainable, can be taught efficiently and are minimally prone to errors } \\
\text { Ability to provide GA in a spontaneously breathing patient is invaluable- reduces } \\
\text { the amount of equipment required }\end{array}$ \\
\hline
\end{tabular}




\section{Appendix B-11}

Sobhy, S., Zamora, J., Dharmarajah, K., Arroyo-Manzano, D., Wilson, M., Navaratnarajah, R., . . . Thangaratinam, S. (2016). Anaesthesia-related maternal mortality in low-income and middleincome countries: a systematic review and meta-analysis. Lancet Glob Health, 4(5), e320-327. doi: $10.1016 / \mathrm{s} 2214-109 \times(16) 30003-1$

\begin{tabular}{|c|c|}
\hline Objective & $\begin{array}{l}\text { To obtain precise estimates of anesthesia-attributed deaths in pregnant women } \\
\text { exposed to anesthesia and to identify the factors linked to adverse outcomes in } \\
\text { pregnant women exposed to anesthesia in low-income and middle-income } \\
\text { countries. }\end{array}$ \\
\hline Findings & 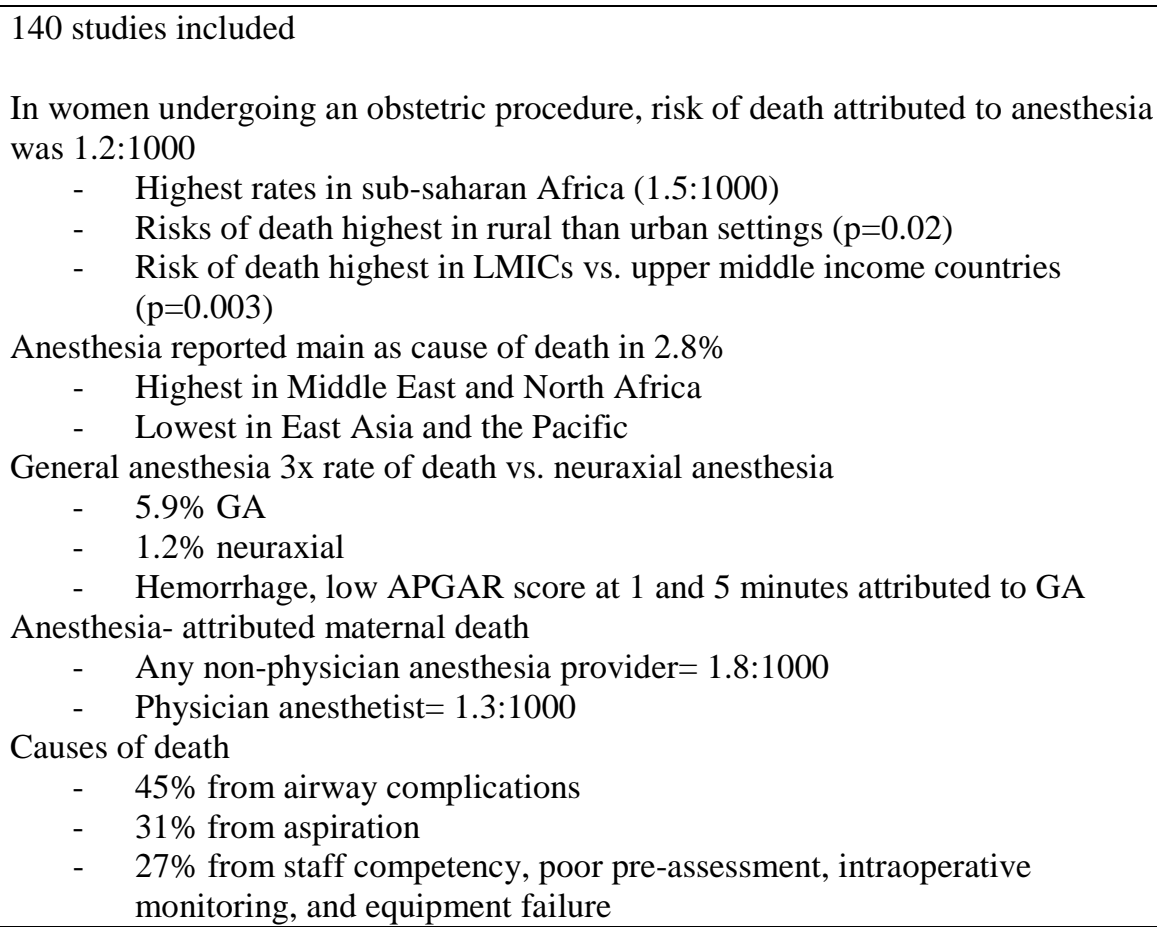 \\
\hline $\begin{array}{l}\text { Anesthesia- } \\
\text { related causes of } \\
\text { morbidity and } \\
\text { mortality }\end{array}$ & $\begin{array}{l}\text { Exposure to general anesthesia and the administration of anesthesia by non- } \\
\text { physicians without any formal training were major risk factors }\end{array}$ \\
\hline $\begin{array}{l}\text { Suggestions/ } \\
\text { interventions to } \\
\text { reduce MMR }\end{array}$ & $\begin{array}{l}\text { The global definition and classification of anesthesia-attributed deaths needs } \\
\text { standardization } \\
\text { Increasing the number of anesthesia practitioners managing pregnancy, enhancing } \\
\text { resources available to them, and increasing their level of training in LMICs } \\
\text { Implementation of simple measures such as WHO Safer Surgery checklist before } \\
\text { and during surgery, access to sampling monitoring technology such as pulse- } \\
\text { oximeters could reduce adverse outcomes. }\end{array}$ \\
\hline
\end{tabular}




\section{Appendix B-12}

Epiu, I., Tindimwebwa, J. V., Mijumbi, C., Chokwe, T. M., Lugazia, E., Ndarugirire, F., . . Dubowitz, G. (2017). Challenges of Anesthesia in Low- and Middle-Income Countries: A Cross-Sectional Survey of Access to Safe Obstetric Anesthesia in East Africa. Anesth Analg, 124(1), 290-299. doi: 10.1213/ane.0000000000001690

\begin{tabular}{|c|c|}
\hline Objective & $\begin{array}{l}\text { Assist in understanding the challenges to providing safe anesthesia in the East } \\
\text { Africa community and in identifying gaps that need to be addressed }\end{array}$ \\
\hline Findings & 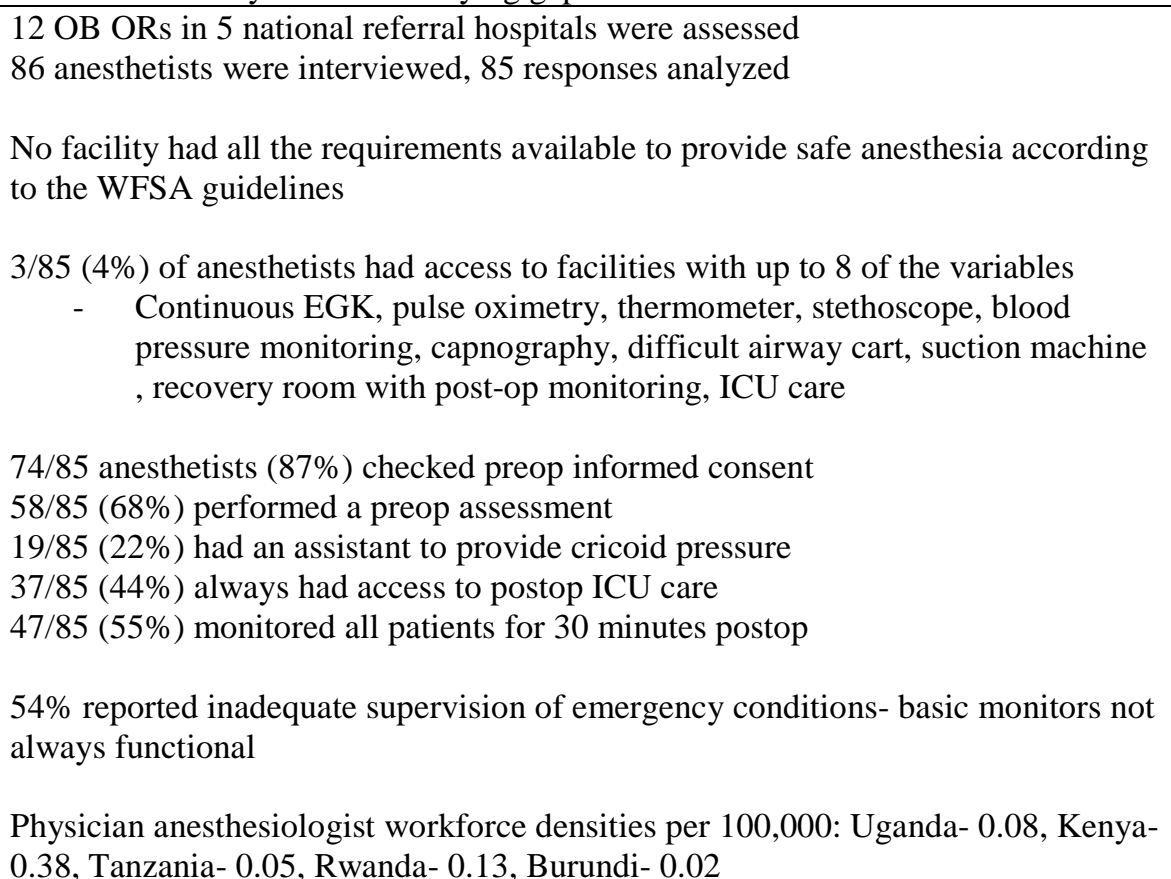 \\
\hline $\begin{array}{l}\text { Anesthesia- } \\
\text { related causes of } \\
\text { morbidity and } \\
\text { mortality }\end{array}$ & $\begin{array}{ll}\text { - } & \text { Lack of reliably working equipment } \\
\text { - } & \text { Lack of proper patient assessment } \\
\text { - } & \text { Lack of assistance in procedures (ie. Cricoid pressure) } \\
\text { - } & \text { Lack of postop care for critically ill mothers } \\
\text { - } & \text { Lack of acceptable postop monitoring } \\
\text { - } & \text { Lack of continuous professional development and education on } \\
& \text { managing OB emergencies } \\
& \text { Insufficient number of physician providers }\end{array}$ \\
\hline $\begin{array}{l}\text { Suggestions/ } \\
\text { interventions to } \\
\text { reduce MMR }\end{array}$ & $\begin{array}{l}\text { Implementation of basic protocols } \\
\text { Governments should ensure that the basic equipment needed to provide safe care } \\
\text { is available } \\
\text { More funding for training of anesthetists in obstetrics } \\
\text { Supervision of non-physician anesthetists by MD anesthetists- requires investment } \\
\text { in training of anesthesiologists to reach the goal of } 20 / 100,000 \text { obstetric } \\
\text { physicians }\end{array}$ \\
\hline
\end{tabular}




\section{Appendix C}

\section{Cross Table Analysis}

\begin{tabular}{|c|c|}
\hline Title & $\begin{array}{l}\text { Caesarean section in Malawi: prospective study of early maternal and } \\
\text { perinatal mortality. } \\
\text { Fenton, P. M., Whitty, C. J., \& Reynolds, F. (2003). }\end{array}$ \\
\hline Key Findings & $\begin{array}{cl}85 & \text { maternal deaths- MMR } 1.05 \% \\
- & 68 \text { in district hospitals }(1.3 \%) \\
- & 17 \text { in urban hospitals }(0.6 \%) \\
- & 68 \text { with trained anesthetists }(0.9 \%) \\
- & 17 \text { with untrained anesthetist }(2.4 \%) \\
- & 4 \text { under spinal anesthesia }(0.13 \%) \\
- & 79 \text { under general anesthesia }(1.6 \%) \\
\text { Complications related to maternal deaths } \\
\text { - } \quad \text { Ruptured uterus: } 35 \text { deaths }(41 \%) \\
\text { - } \quad \text { Intraop hypotension: } 64(75 \%) \\
\text { - } \quad \text { Operative hemorrhage: } 45(53 \%) \\
\text { - } \quad \text { Ventilation difficulty: } 12(14 \%) \\
\text { - } \quad \text { Aspiration: } 11(13 \%) \\
\text { - } \quad \text { Preeclampsia: } 7(8 \%) \\
\text { Strong correlation between increasing blood deficit and mortality } \\
\text { - } \quad 45 \text { cases who died, blood deficit was }>2 \text { units } \\
\text { - } \quad \text { Odds ratio for death in those with more than } 2 \text { units deficit: } 22.1\end{array}$ \\
\hline Recommendations & $\begin{array}{l}\text { Better fluid resuscitation } \\
\text { Training in spinal anesthesia } \\
\text { Training of anesthesia providers to manage care in the ward postoperatively } \\
\text { and provide basic resuscitation }\end{array}$ \\
\hline Title & $\begin{array}{l}\text { Anaesthesia associated mortality in a district hospital in Zimbabwe: } 1994 \text { to } \\
2001 . \\
\text { Glenshaw, M., \& Madzimbamuto, F. D. (2005). }\end{array}$ \\
\hline Key Findings & $\begin{array}{l}77 \text { maternal deaths- MMR } 0.36 \% \\
7 \text { deaths within } 24 \text { hours of anesthesia } \\
-\quad \text { All had emergency surgery } \\
-\quad \text { C-section rate of } 9.6 \% \\
-\quad \text { MMR }=1: 334 \\
-\quad 9.1 \% \text { of maternal deaths } \\
5 \text { deaths directly attributed to anesthesia- } 4 / 5 \text { received spinal anesthesia } \\
\text { Bleeding and the lack of availability of blood contributed to the death of at } \\
\text { least one patient }\end{array}$ \\
\hline Recommendations & $\begin{array}{l}\text { There needs to be more trained anesthesia providers- physician or nurse } \\
\text { anesthetists } \\
\text { Skilled monitoring needs to be performed with spinal anesthesia with } \\
\text { adequate equipment available to recognize potential complications } \\
\text { The ability to convert to GA with intubation is needed when resuscitation is } \\
\text { required }\end{array}$ \\
\hline
\end{tabular}




\begin{tabular}{|c|c|}
\hline Title & $\begin{array}{l}\text { Factors associated with anaesthesia-related maternal mortality in a tertiary } \\
\text { hospital in Nigeria. } \\
\text { Enohumah, K. O., \& Imarengiaye, C. O. (2006). }\end{array}$ \\
\hline Key Findings & $\begin{array}{l}\text { 84 maternal mortalities- MMR 678/100,000 } \\
-\quad 5 \text { deaths associated with anesthesia for c/s- MMR 40/100,000 } \\
-\quad 1 \text { death associated with anesthesia for cervical cerclage } \\
\text { C/s with GA- } 2929(87 \%) \\
\text { C/s with spinal- } 272(11.7 \%) \\
\text { C/s with epidural- } 31(1.3 \%) \\
\text { 6/6 patients who died received GA } \\
-\quad 1=\text { aspiration } \\
-\quad 4=\text { difficult airway/failed intubation/ esophageal intubation } \\
-\quad 1=\text { failure to apply knowledge }\end{array}$ \\
\hline Recommendations & $\begin{array}{l}\text { Emphasis on regional anesthesia for C/S may lead decrease in anesthesia- } \\
\text { related airway problems } \\
\text { Monitoring in the perioperative period should be optimal- the availability of } \\
\text { relevant monitors such as pulse-oximetry and capnography is necessary } \\
\text { Enforcement of a minimal level of training and experience- create policies } \\
\text { prioritizing obstetric anesthesia services }\end{array}$ \\
\hline Title & $\begin{array}{l}\text { WHO analysis of causes of maternal death: a systematic review. } \\
\text { Khan, K. S., Wojdyla, D., Say, L., Gülmezoglu, A. M., \& Van Look, P. F. A. } \\
\text { (2006). }\end{array}$ \\
\hline Key Findings & 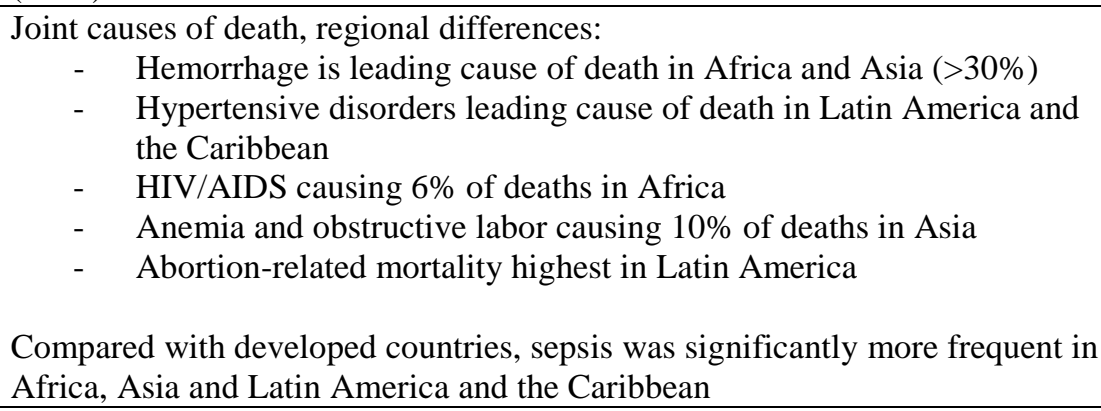 \\
\hline Recommendations & $\begin{array}{l}\text { The absence of epidemiological information in many low-income countries } \\
\text { should lead to efforts to increase capacity for data collection and reporting for } \\
\text { vital statistics }\end{array}$ \\
\hline Title & $\begin{array}{l}\text { Anaesthesia services in developing countries: defining the problems. } \\
\text { Hodges, S. C., Mijumbi, C., Okello, M., McCormick, B. A., Walker, I. A., \& } \\
\text { Wilson, I. H. (2007). }\end{array}$ \\
\hline Key Findings & $\begin{array}{cl}\text { General } & \text { Anesthesia for adults } \\
- & 23 \% \text { met minimum requirements for safe provision of anesthesia } \\
- & 74 \% \text { without a pulse oximeter } \\
- & 23 \% \text { without a tilting OR table } \\
- & 22 \% \text { without an oxygen source } \\
- & 21 \% \text { without appropriate ETT size, many were reused } \\
\text { Facilities } & \\
- & 44 \% \text { water not always available } \\
- & 80 \% \text { electricity not always available } \\
- & 30 \% \text { IV fluids not always available } \\
- & 57 \% \text { had access to hemoglobin lab results }\end{array}$ \\
\hline
\end{tabular}




\begin{tabular}{|c|c|}
\hline & $\begin{array}{ll}\text { - } & \text { 36\% had ability to repair equipment } \\
\text { Spinal Anesthesia } \\
\text { - } & 59 \% \text { did not have spinal anesthetic solution at least some of the time } \\
\text { - } & \text { "Surgeons do not like the technique” } \\
\text { - } & \text { "No spinal needles. The district cannot afford" } \\
\text { Cesarean } & \text { Section } \\
- & 6 \% \text { able to provide safe anesthesia } \\
\text { - } & 78 \% \text { did not have magnesium sulfate at least some of the time } \\
\text { - } & 13 \% \text { did not have oxytocin or ergometrine for some of the time } \\
\text { Drug Availability } & \\
\text { - } & \text { Ketamine- } 92 \% \\
\text { - } & \text { Ether- } 68 \% \\
\text { - } & \text { Succinylcholine- } 54 \% \\
\text { - } & \text { Morphine- } 45 \%\end{array}$ \\
\hline Recommendations & $\begin{array}{l}\text { Ensuring products, such as Ketamine and Halothane, are still available for use } \\
\text { despite their limited profitability to companies, is crucial for anesthesia care in } \\
\text { LMICs } \\
\text { Increasing political awareness of the issues at local and national levels } \\
\text { Increasing numbers of trained personnel } \\
\text { Defining local and national standards of care } \\
\text { Improving logistical arrangements for the supply of equipment and drugs } \\
\text { Consideration of the design of healthcare systems and the need for capital } \\
\text { investment in pulse-oximetry }\end{array}$ \\
\hline Title & $\begin{array}{l}\text { A retrospective study of the outcome of cesarean section for women with } \\
\text { severe pre-eclampsia in a third world setting. } \\
\text { Ajuzieogu, O. V., Ezike, H. A., Amucheazi, A. O., \& Enwereji, J. (2011). }\end{array}$ \\
\hline Key Findings & $\begin{array}{ll}\text { 37/116 } & \text { (38.5\%) received subarachnoid block } \\
- & 11 \text { emergencies } \\
- & 2 \text { maternal deaths } \\
- & 1 \text { anesthetic complications } \\
- & \text { No significance found } \\
59 / 116 & (61.5 \%) \text { received GA } \\
- & 19 \text { emergencies } \\
- & 7 \text { maternal deaths } \\
- & 5 \text { anesthetic complications } \\
- & \text { No significance found } \\
\text { APGAR scores }<7 \text { at } 1 \text { minute: } \\
-\quad 10 \text { babies in subarachnoid group } \\
-\quad 33 \text { babies in GA group } \\
-\quad \text { Significance found } \\
\text { APGAR scores }<7 \text { at } 5 \text { minutes: } \\
-\quad 5 \text { babies from subarachnoid group } \\
-\quad 21 \text { babies in GA group } \\
-\quad \text { Significance found }\end{array}$ \\
\hline Recommendations & $\begin{array}{l}\text { The absence of studies from similar study environments showing the safety of } \\
\text { subarachnoid blocks over GA for severe preeclampsia may contribute to the } \\
\text { larger percentage of GA procedures in this study. }\end{array}$ \\
\hline Title & $\begin{array}{l}\text { Defining the anesthesia gap for reproductive health procedures in resource- } \\
\text { limited settings. }\end{array}$ \\
\hline
\end{tabular}




\begin{tabular}{|c|c|}
\hline & $\begin{array}{l}\text { Anderson, R. E., Ahn, R., Nelson, B. D., Chavez, J., de Redon, E., \& Burke, } \\
\text { T. (2014). }\end{array}$ \\
\hline Key Findings & 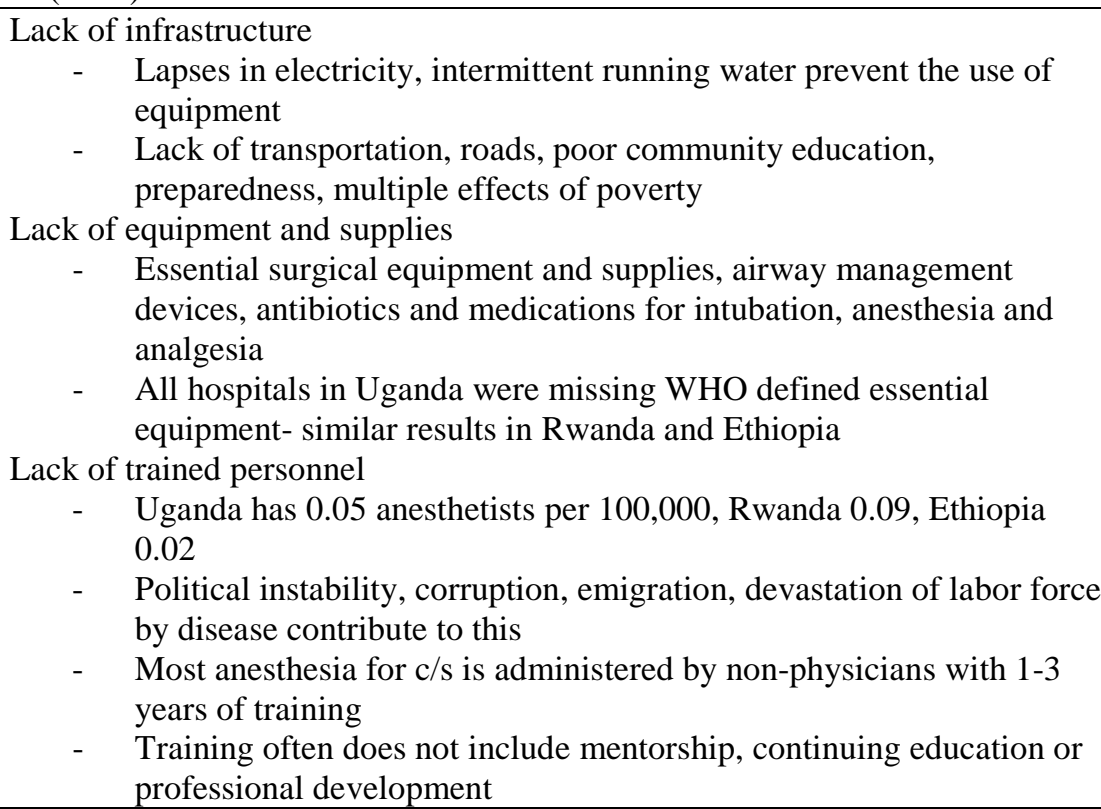 \\
\hline Recommendations & $\begin{array}{l}\text { New and innovative ideas are required to address the findings- must be rapid, } \\
\text { high-impact and cost effective } \\
\text { Development of affordable monitoring devices and simple but safe clinical } \\
\text { protocols that take into account resource-limited challenges }\end{array}$ \\
\hline Title & $\begin{array}{l}\text { Shortage of doctors, shortage of data: a review of the global surgery, } \\
\text { obstetrics, and anesthesia workforce literature. } \\
\text { Hoyler, M., Finlayson, S. R., McClain, C. D., Meara, J. G., \& Hagander, L. } \\
\text { (2014). }\end{array}$ \\
\hline Key Findings & $\begin{array}{l}\text { Anesthesiologist density } 0-4.9: 100,000 \\
\text { GDP per capita significantly correlated with total physician density }(\mathrm{p}=0.004)\end{array}$ \\
\hline Recommendations & $\begin{array}{l}\text { A need for comprehensive surgical workforce data at the national level to } \\
\text { identify factors that correlate and potentially contribute to surgical workforce } \\
\text { shortages, possible consequences of inadequate workforce, such as the MMR } \\
\text { This information would help researchers and policy makers identify the cause } \\
\text { of workforce crisis, inform international responses to the crisis, and establish a } \\
\text { new metric for assessing the strength of healthcare systems } \\
\text { Help to identify the extent and impact anesthesiologist migration has on the } \\
\text { workforce crisis } \\
\text { Numerical evidence of a dwindling workforce can reshape high-income } \\
\text { countries approaches to international recruitment from LMICs }\end{array}$ \\
\hline Title & $\begin{array}{l}\text { Assessment of cesarean delivery availability in } 26 \text { low- and middle-income } \\
\text { countries: a cross-sectional study. } \\
\text { Ologunde, R., Vogel, J. P., Cherian, M. N., Sbaiti, M., Merialdi, M., \& Yeats, } \\
\text { J. (2014). }\end{array}$ \\
\hline Key Findings & $\begin{array}{cl}\text { Referral } & \\
- & 126 \text { referred the procedure to another facility } \\
- & \text { Private/ NGO/ mission hospitals provided most C/S }\end{array}$ \\
\hline
\end{tabular}




\begin{tabular}{|c|c|}
\hline & $\begin{array}{cl}\text { - } & \text { Referral most common in health centers } \\
\text { - } & \text { Most common reasons for referral: lack of skills, nonfunctioning } \\
\text { Essential surgical elements } \\
\text { - } \quad \text { Consistent availability of an oxygen supply: } 78.8 \% \\
\text { - } \quad \text { An anesthesia machine: } 66.7 \% \\
\text { - } \quad \text { A blood bank: } 39.8 \% \\
\text { - } \quad \text { A statistically significant difference was found in the availability of } \\
\text { essential surgical elements between facilities performing and those } \\
\text { not performing but referring C/S } \\
\text { Human Resources } \\
\text { - Nurses or non-physician anesthetists were most common provider of } \\
\text { anesthesia } \\
\text { - } \quad \text { For those referring due to lack of skills, only } 4 \text { had an } \\
\text { - } \quad 251 \text { facilities reported performing C/S without an anesthesia provider }\end{array}$ \\
\hline Recommendations & $\begin{array}{l}\text { Efforts to increase surgical and obstetric capacity and availability of } \mathrm{C} / \mathrm{S} \text { need } \\
\text { to focus on addressing deficiencies in key infrastructure items and meeting the } \\
\text { training needs of the healthcare workforce }\end{array}$ \\
\hline Title & $\begin{array}{l}\text { Providing Anesthesia Care in Resource-limited Settings: A 6-year Analysis of } \\
\text { Anesthesia Services Provided at Medecins Sans Frontieres Facilities. } \\
\text { Ariyo, P., Trelles, M., Helmand, R., Amir, Y., Hassani, G. H., Mftavyanka, J., } \\
\text { _. Latif, A. (2016). }\end{array}$ \\
\hline Key Findings & $\begin{array}{l}\text { Spinal anesthesia was most common- } 34,413 \text { procedures (45.65\%) } \\
\text { GA was second most common- 25,566 procedures ( } 33.85 \%) \\
\text { Spinal anesthesia most common for obstetric/gynecologic/ urologic } \\
\text { procedures- 23,671 (69.45\%) } \\
\text { Perioperative mortality } 0.25 \% \\
\text { Emergent cases compared to elective- AOR } 15.86 \\
\text { Obstetric/GYN/urologic compared to minor surgery- AOR } 3.82 \\
\text { Spinal anesthesia compared to GETA- AOR } 0.10\end{array}$ \\
\hline Recommendations & $\begin{array}{l}\text { Keep delivery of care simple } \\
\text { Streamline anesthetics to a basic and conservative list of drugs and procedures } \\
\text { that are sustainable, can be taught efficiently and are minimally prone to errors } \\
\text { Ability to provide GA in a spontaneously breathing patient is invaluable- } \\
\text { reduces the amount of equipment required }\end{array}$ \\
\hline Title & $\begin{array}{l}\text { Anaesthesia-related maternal mortality in low-income and middle-income } \\
\text { countries: a systematic review and meta-analysis. } \\
\text { Sobhy, S., Zamora, J., Dharmarajah, K., Arroyo-Manzano, D., Wilson, M., } \\
\text { Navaratnarajah, R., . . Thangaratinam, S. (2016). }\end{array}$ \\
\hline Key Findings & $\begin{array}{cl}\text { Obstetric MMR }=0.12 \% \\
-\quad & \text { Highest rates in sub-saharan Africa }(1.5: 1000) \\
- & \text { Risks of death highest in rural than urban settings }(\mathrm{p}=0.02) \\
- & \text { Risk of death highest in LMICs vs. upper middle income countries } \\
& (\mathrm{p}=0.003) \\
\text { Anesthesia reported main as cause of death in } 2.8 \% \\
-\quad & \text { Highest in Middle East and North Africa } \\
- & \text { Lowest in East Asia and the Pacific } \\
\text { General anesthesia 3x rate of death vs. neuraxial anesthesia } \\
-\quad & 5.9 \% \text { GA } \\
- & 1.2 \% \text { neuraxial }\end{array}$ \\
\hline
\end{tabular}




\begin{tabular}{|c|c|}
\hline & $\begin{array}{cl}\text { - } & \text { Hemorrhage, low APGAR score at } 1 \text { and } 5 \text { minutes attributed to GA } \\
\text { Anesthesia- attributed maternal death } \\
-\quad \text { Any non-physician anesthesia provider= 1.8:1000 } \\
\text { - } \quad \text { Physician anesthetist= 1.3:1000 } \\
\text { Causes of death } \\
-\quad \text { } \\
-\quad 3 \% \text { from airway complications } \\
-\quad \text { 27\% from aspiration } \\
\quad \text { monitoring, and equipment failure }\end{array}$ \\
\hline Recommendations & $\begin{array}{l}\text { The global definition and classification of anesthesia-attributed deaths needs } \\
\text { standardization } \\
\text { Increasing the number of anesthesia practitioners managing pregnancy, } \\
\text { enhancing resources available to them, and increasing their level of training in } \\
\text { LMICs } \\
\text { Implementation of simple measures such as WHO Safer Surgery checklist } \\
\text { before and during surgery, access to sampling monitoring technology such as } \\
\text { pulse-oximeters could reduce adverse outcomes. }\end{array}$ \\
\hline Title & $\begin{array}{l}\text { Challenges of Anesthesia in Low- and Middle-Income Countries: A Cross- } \\
\text { Sectional Survey of Access to Safe Obstetric Anesthesia in East Africa. } \\
\text { Epiu, I., Tindimwebwa, J. V., Mijumbi, C., Chokwe, T. M., Lugazia, E., } \\
\text { Ndarugirire, F., . . Dubowitz, G. (2017). }\end{array}$ \\
\hline Key Findings & $\begin{array}{l}\text { No facility had all the requirements available to provide safe anesthesia } \\
\text { according to the WFSA guidelines } \\
\text { 3/85 (4\%) of anesthetists had access to facilities with up to } 8 \text { of the variables } \\
\text { - Continuous EGK, pulse oximetry, thermometer, stethoscope, blood } \\
\text { pressure monitoring, capnography, difficult airway cart, suction } \\
\text { machine, recovery room with post-op monitoring, ICU care } \\
\text { 74/85 anesthetists ( } 87 \%) \text { checked preop informed consent } \\
58 / 85 \text { (68\%) performed a preop assessment } \\
\text { 19/85 (22\%) had an assistant to provide cricoid pressure } \\
37 / 85 \text { (44\%) always had access to postop ICU care } \\
47 / 85 \text { (55\%) monitored all patients for } 30 \text { minutes postop } \\
\text { 54\% reported inadequate supervision of emergency conditions- basic monitors } \\
\text { not always functional } \\
\text { Physician anesthesiologist workforce densities per } 100,000 \text { : Uganda- } 0.08 \text {, } \\
\text { Kenya-0.38, Tanzania- } 0.05 \text {, Rwanda- } 0.13 \text {, Burundi- } 0.02\end{array}$ \\
\hline Recommendations & $\begin{array}{l}\text { Implementation of basic protocols } \\
\text { Governments should ensure that the basic equipment needed to provide safe } \\
\text { care is available } \\
\text { More funding for training of anesthetists in obstetrics } \\
\text { Supervision of non-physician anesthetists by MD anesthetists- requires } \\
\text { investment in training of anesthesiologists to reach the goal of 20/100,000 } \\
\text { obstetric physicians }\end{array}$ \\
\hline
\end{tabular}

